Posebna izdanja: br. 17

STEFANOVIĆ V., BEUS V., BURLICA ¿..,

DIZDAREVIĆ H., VUKOREP I.

\title{
EKOLOŠKO-VEGETACIJSKA REJONIZACIJA BOSNE I HERCEGOVINE
}

\author{
OKOLOGISCH — VEGETATIONSKUNDLICHE GLIEDERUNG \\ BOSNIENS UND DER HERZEGOWINA
}

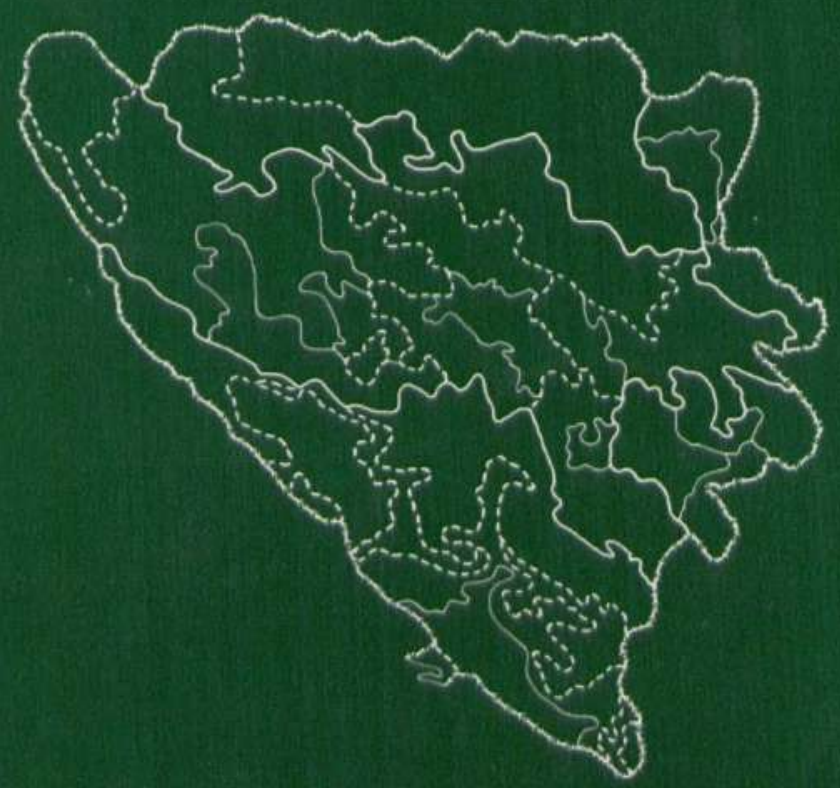

Sarajevo, 1983. godine 

Posebna izdanja: br. 17

STEFANOVIC V., BEUS V., BURLICA C.,

DIZDAREVIC H., VUKOREP I.

\section{EKOLOŠKO-VEGETACIJSKA REJONIZACIJA BOSNE I HERCEGOVINE}

OKOLOGISCH - VEGETATIONSKUNDLICHE GLIEDERUNG BOSNIENS UND DER HERZEGOWINA 


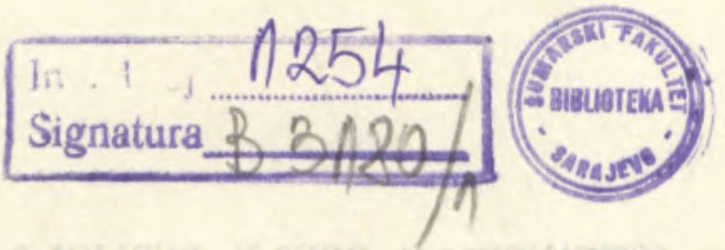

$$
\text { Uređuje: }
$$

Komisija za izdavačku djelatnost Sumarskog fakulteta

u Sarajevu

Prof. dr Ostoja Stojanović, predsjednik

Prof. dr Vitomir Stefanović, urednik

Prof. dr Midhat Uščuplić

Prof. dr Ivan Vukorep

Asistent Dušan Miodragović, sekretar

\section{Recenzen $t$ i:}

Dr Loti Manuševa, naučni savjetnik

Dr Nešad Bojadžić, naučni saradnik

Ing. Branibor Fabijanić, naučni saradnik

\section{Lektor:}

Jasminka Melkić, profesor

Tiraž: 500 primjeraka

Uredništvo i administracija: Sumarski fakultet - Sarajevo,

Zagrebačka 20

Telefon: (071) 611-033

Stampa: ZO „DES, ajevo

Za štampariju: Graf. inž. Sulejman Fejzagić 


\section{S A D R Z A J}

PREDGOVOR

Str.

\section{OPST I D IO}

1. UVOD . . . . . . . . . . . . . . . . . 7

2. OSNOVE EKOLOSKO-VEGETACIJSKE REJONIZACIJE BOSNE I HERCEGOVINE . . . . . . . . . . . . . . . 7

2.1. Klima + . . . . . . . . . . . . . . . 7

2.2. Pedološka istraživanja . . . . . . . . . . . . . 8

2.3. Fitocenološka i tipološka istraživanja . . . . . . . 8

3. METODOLOSKI PRISTUP . . . . . . . . . . . . 9

3.1. Kriterij ekološko-vegetacijske rejonizacije . . . . . . . 9

3.2. Terminološko značenje vegetacijskih jedinica . . . . . . . 9

3.3. Izbor i metod obrade klimatskih podataka . . . . . . . 10

3.4. Metod izrade Pedološke karte Bosne i Hercegovine (R 1:200.000) 10

3.5. Metod izrade Karte realne sumske vegetacije Bosne i Hercegovine (R 1:200.000) . . . . . . . . . . . . . . 10

3.6. Metod izrade Karte potencijalne vegetacije Bosne i Hercegovine (R 1:200.000)

4. FITOGEOGRAFSKE I EKOLOSKE KARAKTERISTIKE BOSNE I HERCEGOVINE

4.1. EUROSIBIRSKA-SJEVEROAMERICKA REGIJA

4.1.1. Pojas hrastovih šuma nizijskog $\mathrm{i}$ brdskog područja ilirske i prelazno ilirsko-mezijske provincije . . . . . 4.1.2. Gorski pojas bukve, bukve i jele, bukve i jele sa smrčom i subalpinski pojas bukve (Fagetalia) . . . . . 11

4.2. MEDITERANSKA REGIJA . . . . . . . . . . . 12

4.2.1. Eumediteranska zona zimzelene vegetacije sveze Quercion ilicis . . . . . . . . . .

4.2.2. Submediteranska zona i mediteransko montani pojas listopadne vegetacije sveze Ostryo-Carpinion . . . . 12

\section{POSEB N I D I O}

PREGLED EKOLOSKO-VEGETACIJSKIH REJONA BOSNE I HERCEGOVINE

1. PRIPANONSKA OBLAST . . . . . . . . . . . . . . 16

1.1. Sjeverobosansko područje . . . . . . . . . . . . 16

1.2. Sjeverozapadnobosansko područje . . . . . . . . . 16

2. PRELAZNO ILIRSKO-MEZIJSKA OBLAST . . . . . . . 16

2.1. Donje drinsko područje . . . . . . . . . . . 20

2.1.1. Semberijsko-posavski rejon . . . . . . . . . 20

2.1.2. Majevički rejon . . . . . . . . . . . 21

2.1.3. Srebrenički rejon . . . . . . . . . . . 21 
Stampanje ove publikacije, sa svim prilozima i kartama, omogućili su svojim finansiskim sredstvima: SIZ za nauku SR BiH, SOUR »ŠIPAD«, IK "KRIVAJA" sa OOUR šumarstva "Ribnica" - Kakanj, OOUR "Borja" Teslić i OOUR šumarstva "Krivaja» - Zavidovići. Svima se najtoplije zahvaljujemo.

Uvjereni smo da će rezultati ovih istraživanja korisno poslužiti osnovnoj namjeni - unapređenju sjemenarstva i rasadničke proizvodnje te planiranju proizvodnje u šumarstvu, a očekujemo da će ona koristiti i valorizaciji prostora i prostornom planiranju u Bosni i Hercegovini, te vodoprivredi, poljoprivredi, nauci, obrazovanju i drugim oblastima.

Autori 


\section{O PŠT I D I O}

\section{UVOD}

Rejonizacije šumskih područja u svijetu vršene su uglavnom radi sagledavanja potencijala šumskih staništa i njihovog racionalnog korištenja u različite namjene. One su se uvijek temeljile na ekološko-vegetacijskim osnovama. U zemljama u kojima je prirodna šumska vegetacija bila u prošlosti znatnije izmijenjena, osnovna kategorizacija područja zasnivala se na izdvajanju takvih fitogeografskih cjelina koje bi, na osnovu rekonstrukcije klimazonalnih i klimaregionalnih vegetacijskih jedinica, predstavljale homogene cjeline.

Ovaj princip je zastupljen podjednako u rejonizacijama šumskih oblasti (TSCHERMAK, L. 1960, 1961, MAYER et al. 1971,WRABER, M. 1960, RADKOV, I. 1963, OBERDORFER, E. 1948, RUBNER, K. 1953), kao i u ekološko-proizvodnim klasifikacijama šuma (SCHLENKER, G. 1962, JELEM, H. 1960, OTTO, H. J., 1972) i drugi.

Kod nas je on došao samo dijelom do izražaja $u$ pokušajima fitogeografske podjele Jugoslavije, u radovima HORVATA, I. (1954), HORVATA $I$. et al. (1974), HORVATICA, S. (1967), FUKAREKA, P. (1977, 1977b, 1978, 1979.), TRINAJSTICA, I. (1978, 1980), LAKUSICA, $R$. (1975), i drugih.

Međutim, ove podjele su imale pretežno fitogeografski karakter, jer su se strogo oslanjale na nivo dosadašnjih saznanja o horologiji flornih elemenata, odnosno sinhorologiji biljnih zajednica i njihovih sintaksomonskih kategorija višeg sistematskog ranga, a kartografski su bile predstavljene najglobalnijim ilustracijama podjele područja, karaktera skica, odnosno preglednih karata.

Za Bosnu i Hercegovinu vrijedan je spomena jedan pokušaj rejonizacije koji su učinili BURLICA Č. et $F A$ BIJANIC, B. (1968) na principu karakterisanja izdvojenih područja sličnih klimatskih, geomorfoloških, geološko-,pedoloških i vegetacijskih svojstava, a koji je ilustrovan sa globalnim prikazom u vidu skice - karte. Više primijenjenog karaktera pokušaj sjemenske rejonizacije, dali su $Đ I K I C$, $S$, et al. (1965).

Pridržavajući se ovog principa i radovi na tipološkim (ekološko-proizvodnim) klasifikacijama šuma kod nas nose mnoga zajednička obilježja zasnovana na rejonizaciji šumskih područja. Klimazonalne i klimaregionalne zajednice uzete su kao osnovni fitogeografsko-klimatski okviri u kojima su izdiferencirane niže, ekološko-vegetacijske i proizvodne jedinice (CESTAR, D. et al. 1970, CIRIC, M. et al. 1971, FABIJANIC, B. et al. 1966, STEFANOVIC, V. 1972, JOVIC, D. et al. 1979, BURLICA, C. 1979. i drugi).
Međutim, primijenjene tipološke klasifikacije imaju svoje ciljeve i zadatke, koji se pretežno sastoje u definisanju proizvodnih potencijala šumskih staništa i nisu se mogle neposredno koristiti za ekološko-vegetacijsku rejonizaciju Bosne i Hercegovine. Tim prije, što u Bosni i Hercegovini dosad obrađeni tipovi šuma nisu mogli biti prikazani i kartografski zbog primijenjenog metoda prikupljanja terenskih podataka.

$\mathrm{Da}$ bi se moglo prići ekološko-vegetacijskoj rejonizaciji i njenom kartografskom prikazu u razmjeri 1:200.000 nužno je bilo ispuniti slijedeće preduslove:

- raspolagati sa kartama šumske vegetacije krupnijeg mjerila za čitavu teritoriju Bosne i Hercegovine, sa geografski ograničenim klimazonalnim i klimaregionalnim šumskim fitocenozama, kao i drugim šumskim zajednicama azonalnog i intrazonalnog karaktera, te poznavati zakonitosti njihovog rasprostranjenja;

- imati pedološke karte krupnije razmjere koje odražavaju zakonitosti rasprostranjenja pedoloških jedinica i njihovih ekoloških karakteristika u Bosni i Hercegovini;

- raspolagati sa klimatskim podacima za vremenski duži period osmatranja, odabrati relevantne meteorološke stanice, te pronaći metod rada za izdvajanje osnovnih parametara za klimatsko karakterisanje izdiferenciranih područja Bosne i Hercegovine.

\section{OSNOVE EKOLOŠKO-VEGETACIJSKE REJONIZACIJE BOSNE I HERCEGOVINE}

Za sticanje realne predstave o ugrađivanju niza elemenata, unutar obrađivanih komponenata i njihovoj sintez ekološko-vegetacjskih rejona Bosne i Hercegovine, analiziraće se, u globalnim potezima naprijed navedeni preduslovi. To su nivoi saznanja zasnovani na dosadašnjim rezultatima istraživanja iz oblasti klimatologije, pedologije, fitocenologije i tipologije šuma u Bosni i Hercegovini, kao i dostignuti nivo izrade kartografske dokumentacije iz navedenih naučnih oblasti.

\subsection{Klima}

Klima Bosne i Hercegovine analizirana je u radovima, počev od MOSCHELES, J. (1918), VEMIC, $M$. (1954), MILOSAVLJEVIC, R. (1976), na osnovu postojeće mreže meteoroloških stanica sa nizom manjkavosti $\mathrm{u}$ pogledu njihovog geografskog $\mathrm{i}$ visinskog rasporeda kao i u neujednačenosti u vremenu osmatarnja.

Karakterisanje klime, na bazi postojeće mreže stanica i njihovih podataka, moglo je da zadovolji opšte potrebe $\mathrm{i}$ da dade odgovor $\mathrm{u}$ sagledavanju globalnih 
klimatskih odnosa, naročito u pogledu uticaja maritimnosti i kontinentalnosti klime pojedinih područja. Isto tako, i novoizrađene karte klimatskih elemenata Jugoslavije (izohijeta, izotermi, itd.) Saveznog hidrometeorološkog zavoda u Beogradu, odnoseći se na teritoriju Bosne i Hercegovine, mogu da pruže samo osnovne uvide u pomenute odnose.

Radovi, pak koji su obrađivali klimatske ili mikroklimatske prilike (LUCIC, V. 1965, STEFANOVIC, V. 1960, 1961) imali su za cilj karakterisanje klime (fitoklime) određenih šumskih područja i šumskih zajednica.

I pored nesumnjivog značaja svih ovih radova za poznavanje klimatskih prilika Bosne i Hercegovine, u pristupu ekološko-vegetacijskoj rejonizaciji, u karakterisanju klime, meteorološke elemente je bilo nužno obraditi $\mathrm{i}$ šire od prosječnih vrijednosti, a posebno iz razloga, ako se na osnovu njih vrši analiza i obračun različitih indeksa (koeficienata), kao značajnih parametara (PINTARIC, K. 1957).

Među ostalim radovima koji su korišteni iz ove oblasti posebno se naglašava rad o analizi prostornog rasporeda suše u Bosni i Hercegovini (MILOSAVLJEVIC, R. 1977), te rad o analizi učestalosti variranja temperature i padavina (VLAHINIC, M. 1969).

Pri karakterisanju klime izdvojenih oblasti odabrane su meteorološke stanice sa relativno najpribližnijim i najujednačenijim meteorološkim podacima za meteorološke elemente: temperaturu vazduha, srednju relativnu vlagu vazduha, srednju sumu padavina, te sa dobijenim indeksima za značajnije parametre $(\mathrm{N} / \mathrm{S}$ koeficient, index trajanja suše - De Martonne, potencijalna evapotranspiracija i dr.).

Objektivne okolnosti su uslovljavale, da se $u$ analizi obuhvate meteorološki podaci iz različitih perioda osmatranja, kao i meteorološke stanice koje nisu uvijek najadekvatnije odgovarale po svom visinskom položaju. Poznato je, naime, da su u današnjoj mreži meteoroloških stanica zastupljena mjesta sa nižom nadmorskom visinom vezana za veća naselja. U ranijim, pak, periodima (1901-1910), dominirale su stanice na planinskim prevojima, vezane za ondašnje žandarmerijske stanice. Podaci sa ovih stanica obrađeni su u posebnoj publikaciji MOSCHELES, J. (1918).

\subsection{Pedološka istraživanja}

Intenzivnija proučavảnja zemljišta na području Bosne i Hercegovine vezana su za period poslije drugog svjetskog rata, posebno se to odnosi na šumska zem. ljišta, koja se intenzivnije proučavaju tek posljednjih 25 godina.

$\mathrm{Ta}$ istraživanja bila su vezana za rasadničku proizvodnju i podizanje nasada brzorastućih četinara, $(P O$ POVIC, B. 1953, 1963), te za proučavanje zakonitosti razvoja zemljišta na pojedinim geološkim supstratima $C I$ RIC, M. $(1959,1961,1966)$, POPOVIC, B. (1964), FABIJANIC, B. et al. (1967), STEFANOVIC, V. i MANUSEVA, L. (1966), MANUSEVA, L. (1971), koja su se obavljala u zajednici sa fitocenolozima.

Za potpunije razumijevanje geneze zemljišta u Bosni i Hercegovini bili su važni radovi o zemljištu na peridotitu i serpentinitu (CIRIC, M. 1962), te na krečnjaku (CIRIC, M. 1967), kao i prilog o uslovima obrazovanja crvenice (CIRIC, M. - ALEKSANDROVIC, D. 1959).

Posebno važno mjesto $u$ prikupljanju informacija o šumskim zemljištima Bosne i Hercegovine bili su radovi na Inventuri šuma na velikim površinama (MATIC et al. 1971), koja je provedena u vremenu od 1963. do 1968. godine. Tada su prikupljeni, pored podataka za taksacione elemente, vegetaciju i podaci o zemljištima na sistematski postavljenoj mreži traktova i krugova MATIC, $V$. (1963). Tako su dobivene značajne informaci- je o zemljištu i odnosima zemljišta - vegetacija ( $V U$ KOREP, I. 1965, CIRIC, M. et al. 1971, 1971 b, STEFANOVIC, $V$. et al. 1973, 1977 a, 1977 b).

U izradi pedološke karte Bosne i Hercegovine korišteni su djelomično i podaci nekih sekcija Pedološke karte Jugoslavije razmjere 1:50.000, koja je započeta 1964. godine i koja je u poodmakloj fazi završnih radova.

Prvih deset godina kartirane su one površine koje su bile od većeg interesa za intenzivnu poljoprivrednu proizvodnju, a tek posljednje decenije završavaju se i šumski regioni. Do sad je kartirano i štampano preko $60 \%$ listova sekcija Bosne i Hercegovine u mjerilu $1: 50.000$

Najpotpunija prostorna predstava o šumskim zemljištima dobivala se sistematski kartiranjem šumskih površina za potrebe izrade šumsko-privrednih osnova koje započinju 1969. godine u zavidovičkom šumsko-privrednom području, izradom pedoloških karata 1:25.000 na najnovijim topografskim osnovama.

$\mathrm{U}$ petnaestogodišnjem periodu kartirano je, na ovaj način, skoro $70 \%$ šumskih površina teritorije Bosne 1 Hercegovine i to na istoj, ili krupnijoj kartografskoj osnovi (M 1:10.000).

Ovo je predstavljalo dragocjeni materijal za izradu ove pedološke karte, M 1:200.000 uz napomenu da su prve karte urađene na osnovu znanja iz perioda pedesetih godina, a shvaćanja o metodi kartiranja i prikazivanja zemljišnog pokrivača su se znatno mijenjala. Tome su doprinijeli naučni skupovi i savjetovanja. Posebno mjesto za kartografiju zemljišta ima Savjetovanje o korišcenju pedoloških karata, na kome je posebno razmatran problem strukture zemljišnog pokrivača (CIRIC, $M .1975$ ).

Boljem poznavanju problema istraživanja, korišćenja šumskih zemljišta BiH doprinjeo je »Simpozijum o problemima istraživanja šumskih zemljišta», Tjentište 1973. godine.

Osim navedenih radova za izradu pedološke karte M 1:200.000 poslužile su kao osnovica i druga istraživanja šumskih zemljišta.

Za produktivnost šumskih zemljišta od značaja su radovi MANUSEVE, $L$. et al. (1976), MILOS, B. (1979), CIRIC, M. (1975), CIRIC, M. et al. (1975), VUKOREP, I. (1975), BURLICA, C. et al. (1975) i dr.

Organska komponenta je značajno obrađena u šumskim zemljištima u radovima MANUŠEVA, L. (1967, 1969, 1975, 1976), VUKOREP, I. (1966), MANUSEVA, L. - CIRIC, M. (1969).

Fizička svojstva zemljišta, a posebno vodno-vazdušni režim šumskih zemljišta prikazan je u radovima BURLICA, C. (1973, 1975), BURLICA, C. et al. (1975).

\subsection{Fitocenološka i tipološka istraživanja}

Sadašnju etapu fitocenoloških istraživanja u Bosni i Hercegovini karakteriše faza sintetizovanja mnogobrojnih utvrđenih činjenica o karakteru vegetacijskih jedinica nižeg $i$ višeg sistematskog ranga, te sagledavanje i objašnjenje širih vegetacijskih odnosa. I sam klasifikacioni sistem, zahvaljujući postignutim rezultatima postao je sadržajniji, mada predstoji mnogo rada na njegovom poboljšavanju.

Istraživanja šumske vegetacije $u$ poslijeratnom periodu u Bosni $\mathrm{i}$ Hercegovini temeljila su se na fundamentalnim osnovama poznavanja vegetacije i njenih odnosa naših klasika botaničara BECK-a, G. (1901), ADAMOVICA, L. $(1907,1909), M A L Y-a, K .(1938,1939)$ i drugih. Sire savremene programske osnove ovim istraživanjima i kartiranju šumske vegetacije Bosne i Hercegovine dao je FUKAREK, P. (1955) koji je dugi niz 


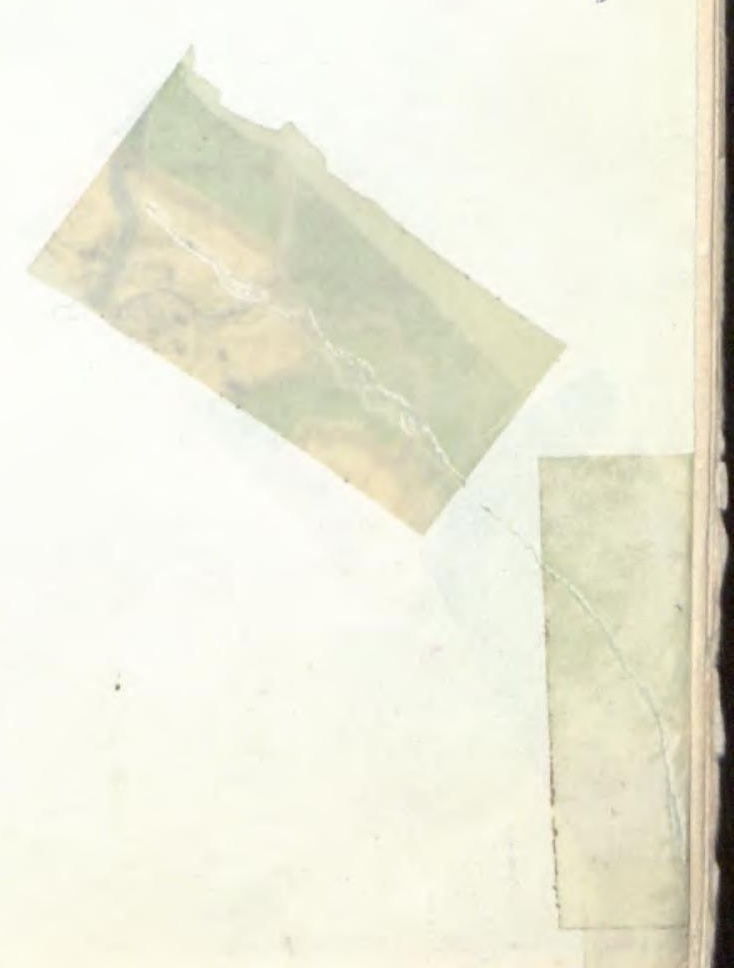




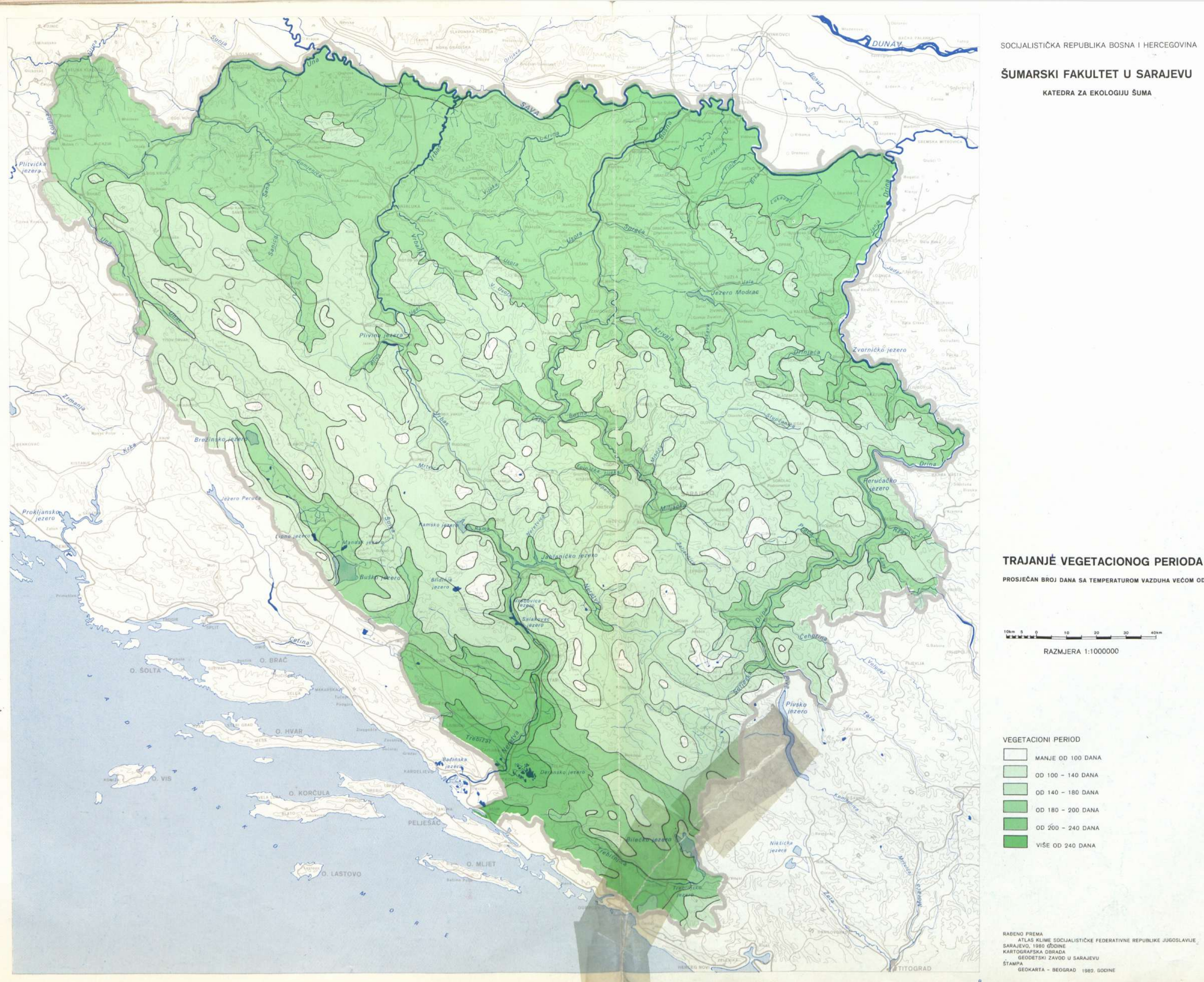


- 
godina rukovodio ovim radovima na čelu Katedre za šumarsku botaniku na Šumarskom fakultetu u Sarajevu.

Zahvaljujući rezultatima njegovih istraživanja i saradnika učinjen je vrlo veliki korak na istraživanju $j$ sagledavanju horoloških, taksonomskih, sinhoroloških, cenoloških karakteristika kako nekih vrsta drveća $i$ grmlja tako i šumskih biljnih zajednica.

Posmatrajući rezultate ovih istraživanja u svjetlu njihove integralne povezanosti sa izradom karata realne $i$ potencijalne šumske vegetacije $u$ razmjeri 1:200.000 osvrnućemo se na njihov karakter.

Po prirodi istraživanja neka od njih se odnose na šumsku vegetaciju pojedinih geografskih područja ( $F U$. KAREK, P. 1962, 1969, 1970), FUKAREK, P. et STEFANOVIC, V. (1958), FABIJANIC, B. et al. (1967), STEFANOVIC, $V$. (1964), i drugi. Niz studija obuhvata istraživanja šumske vegetacije na određenoj geološkoj podlozi, npr. na peridotitu i serpentinitu - RITTER STUDNICKA, H. (1963, 1970), KRAUSE, W. et LUDWIG, W (1957), BEUS, V. (1980); na dolomitu - RITTER STUD NICKA, H. $(1956,1957,1959,1962)$; na verfenskim sedimentima - STEFANOVIC, V. (1964); na permkarbonskim škriljcima i pješčarima - STEFANOVIC, $V$. et MANUSEVA, L. (1966); andezitu i dacitu - STEFANOVIC, V. i MANUSEVA, L. (1971); neki se odnose na istraživanja konkretnih vegetacijskih jedinica, npr. šuma munike, klekovine bora, šuma sladuna (FUKAREK, $P$. 1952, 1966, 1966 b, FUKAREK, P. et al. 1967.), šuma bijelog bora (STEFANOVIC, V. 1960, 1969, 1970) i drugi; neki su, pak, horološkog karaktera i odnose se na sagledavanje horoloških okvira važnijih vrsta drveća i grmlja, npr. areal bukve, jele i smrče na području Bosne i Hercegovine (FUKAREK, P. 1970.), crnog bora (FUKAREK, P. 1958.), bijelog bora (STEFANOVIC, $V$. 1958.) itd.

U navedenim kao i ostalim radovima, sve više se teži proučavanju, povezivanju i definisanju pojava i njihove zakonitosti $u$ integralnom sagledavanju fitogeografskih okvira i njihovih sadržaja, u pogledu flornih elemenata, raščlanjenja vegetacijskih jedinica $i$ fitogeografskih područja na fitogeografskim principima.

Uporedo sa istraživanjima odvijala su se i kartiranja šumske vegetacije u Bosni i Hercegovini kojima je dao programske osnove FUKAREK, P. (1955).

Poslednje decenije izvođena su kartiranja šumske vegetacije u okviru Saveznog projekta „Vegetacijska karta Jugoslavije - teritorij $\mathrm{SR} B \mathrm{BiH} \kappa$ u razmjeri $1: 50.000$

Kao autori pojedinih karata za geografska područja koja smo kartirali i izradili komentare karata u razmjeri 1:50.000 (STEFANOVIC, V. i BEUS, V.) koristili smo ove za izradu Karte realne vegetacije Bosne i Hercegovine. Međutim, potrebno je posebno nagla. siti da se Karta realne šumske vegetacije razmjere $1: 200.000$ i iz nje izvedena Karta potencijalne vegetacije $1: 200.000$ ne bi mogle $\mathrm{u}$ ovom trenutku izraditi da nismo imali na raspolaganju ogromni materijal kartografske dokumentacije, pretežno razmjere $1: 25.000$ novih šumsko-privrednih osnova, koji obuhvata oko $70 \%$ čitave teritorije Bosne i Hercegovine.

Zapravo, zahvaljujući sprovedenoj Inventuri šuma na velikim površinama, $1964-1968$. (MATIC, $V .1963$, MATIC, V. et al. 1971), koja je, pored ostalih pozitivnih rezultata, pružila, sistemskim putem, sakupljeni materijal za tipološku klasifikaciju šuma u Bosni i Hercegovini.

Kasnijim nastojanjima, uglavnom počev od 1969. godine, izrađen je niz šumsko-privrednih osnova na tipološkim principima sa sadržajima kartografske dokumentacije (karte realne šumske vegetacije, osnovnih tipova šuma, proizvodnih tipova šuma u razmjeri
$1: 25.000)$. U početku su radili i lično - BEUS, $V$., $S T E$ FANOVIC, V., BURLICA, C. i VUKOREP, I., tipološku komponentu za neka šumsko-privredna područja (SPP Gostovićko, Vareško, Olovsko, Kupreško, Jahorinsko) a kasnije ove poslove preuzeli su za to obrazovani stručnjaci u okviru projektantske organizacije OOUR "Silva« - SIPAD.

\section{METODOLOSKI PRISTUP}

\subsection{Kriteriji ekološko-vegetacijske rejonizacije}

Primijenjeni metod se zasniva na analizi fitogeografsko-klimatske, pedološke i vegetacijske komponente i njihovoj sintezi, sa osnovnim ciljem da se teritorija Bosne i Hercegovine raščlani na što homogenije jedinice po navedenim obilježjima na karti rejona mjerila $1: 200.000$.

Analizom i sagledavanjem cjelokupne teritorije svrsishodno je i naučno opravdano kreirati tri nivoa kategorija: oblasti, područja i rejone.

Za teritorijalno izdvajanje oblasti diferencijaIni karakteri su: homogena fitogeografsko-klimatska karakteristika, relativna sličnost geomorfoloških i orografskih prilika, zastupljenost jedne ili više svojstvenih, za tu najširu kategoriju, klimazonalnih i klimaregionalnih fitocenoza i njihovih posebnih odlika po sadržaju flornih elemenata i počev od najširih do najužih sinhoroloških jedinica - regija, provincija, sektora,

Druga diferencijalna jedinica područje uklapa se u oblast, po usvojenim kriterijima: da ima uže zajedničke fitogeografske karakteristike i da se odlikuje nekim specifičnim geomorfološkim, orografskim i klimatskim obilježjima. U pogledu šumske vegetacije, takođe se odlikuje sa naglašenim karakterom nekih klimazonalnih i klimaregionalnih zajednica, npr. areal šuma bukve i jele sa smrčom, te šuma bukve i jele bez smrče, rasprostranjenjem većih kompleksa šuma uslovljenih orografsko-edafskim faktorima (šuma bijelog i crnog bora na dolomitu, serpentinitu, krečnjaku, orografsko-edafski uslovljenih hrastovih šuma, itd.).

Unutar izdvojenih područja (ne u svim) izdvojene su jedinice na nivou rejona. Kriteriji za njihovo izdvajanje su uže specifičnosti dijelova teritorije, nekim posebnim geomorfološkim, orografsko-edafskim karakteristikama, (npr. područje srednje Bosne izdiferencirano je na Vrandučki rejon (jurski fliš), Vranički rejon (paleozojsko škriljogorje), Sarajevsko-zenički rejon (tercijerni fliš) ili npr. submediteransko područje unutar mediteransko-dinarske oblasti, izdiferencirano je na rejon sa zimzelenim elementima i rejon bez zimzelenih elemenata, itd.

\subsection{Terminološko značenje vegetacijskih jedinica}

Da bi se otklonile nejasnoće i različita poimanja upotrebljenih termina objasniće se ukratko njihovo značenje.

Pod klimazonalnom vegetacijom shvataju se one šumske zajednice čije je rasprostranjenje uslovljeno makroklimatskim prilikama geografskih regiona (npr. u unutrašnjem i zapadnom dijelu Jugoslavije, zajednica kitnjaka i običnog graba (Querco-Carpinetum);

Klimaregionalne zajednice su rezultat klime sa promjenama nadmorske visine (npr. šume bukve ( $\mathrm{Fa}$ getum montanum) ili šume bukve i jele (Abieti $-\mathrm{Fa}$ getum);

Azonalne i intrazonalne vegetacijske jedinice predstavljaju orografsko-edafski uslovljene zajednice sa posebnom fitoklimom. Dok azonalni tip vegetacije može da bude uključen u svaku vegetacijsku zonu (npr. po- 
plavne livade u dolinama rijeka mogu biti u svakoj zoni, šumskoj, stepskoj, pustinjskoj itd.), zaslanjena vegetacija razvijena je samo u određenim zonama, stepskoj ili pustinjskoj. Kod šumske vegetacije, prvoj pripadaju npr. aluvijalne šume vrba $i$ topola, a drugoj šume javora i jasena (Aceri - Fraxinetum).

Pod ekstrazonalnom vegetacijom podrazumjevamo dijelove (fragmente) neke zonalne vegetacije, koji su se, zahvaljujući specifičnim lokalnim uslovima, mogli razviti i izvan svoje zonalne oblasti (npr. šuma sladuna Quercetum confertae adriaticum u Hercegovini i Crnoj Gori napram klimazonalne zajednice sladuna i cera u Srbiji Quercetum confertae- cerris), itd.

Pod terminom realna vegetacija podrazumjeva se sadašnja tzv. a k tu e ln a ve ge t a ci j a koja je rezultat određenih klimatskih prilika, ali i djelovanja zooantropogenog faktora.

Potencijalna vegetacija odražava, pak, vegetaciju koja bi se razvila na mjesto sadašnje aktuelne vegetacije uz pretpostavku eliminisanja ili znatnog ublažavanja zooantropogenog faktora.

\subsection{Izbor i metod obrade klimatskih podataka}

Za karakterisanje meteoroloških i klimatoloških elemenata za sva izdvojena područja odabrano je osamdeset pet meteoroloških stanica (toliki da bi što bolje reprezentovao sve visinske pojaseve), za koje su obrađeni slijedeći raspoloživi meteorološki elementi:

- Temperatura vazduha, srednja godišnja i srednja za period april - septembar, a suma aktivnih temperatura za period april - septembar (samo sa 16 stanica);

- Relativna vlaga vazduha, srednja godišnja i za period april - septembar (samo sa 57 stanica);

- Padavine, prosječne sume za godinu i period april - septembar;

- N/S koeficijent po MEYER-u (prema PINTARIC-u 1957) pošto obuhvata tri meteorološka elementa (relativnu vlagu i temperaturu vazduha preko deficita zasićenja vlažnosti i suma padavina (prosječni godišnji i za period april-septembar);

- Indeks suše po DE MARTONU uzimanjem u obzir samo sume padavina i temperature vazduha (za period april - septembar); obračunate su sume padavina $\mathrm{i}$ srednje temperature i preračunati na srednje mjesečne vrijednosti;

- Potencijalna evapotranspiracija kao važan pokazatelj uticaja klime na potrošnju vode određena je po metodu THORTHWEITE-a (na osnovu srednjih mjesečnih temperatura vazduha korigovanih prema geografskoj širini položaja meteorološke stanice, pošto se za ovaj metod raspolaže sa više podataka koji omogućavaju pouzdanije razgraničavanje prostora sa različitom potencijalnom evapotranspiracijom);

- Indeks klime po THORTHWEITE-u koji bazira na obračunu viškova $\mathrm{i}$ manjkova vode na osnovu bilansa između potencijalne evapotranspiracije, sume padavina $\mathrm{i}$ rezervi pristupačne vode biljkama u zemljištu;

- Trajanje vegetacionog perioda određeno je na bazi srednjih mjesečnih temperatura vazduha, obračunom broja dana sa temperaturom većom od $10^{\circ} \mathrm{C}$.

\subsection{Metod izrade Pedološke karte Bosne i} Hercegovine (R 1:200.000)

$\mathrm{Za}$ izradu navedene pedološke karte (R 1:200.000) korištena su tri glavna izvora:

- Kartografski materijal Osnovne pedološke karte Bosne i Hercegovine mjerila $1: 50.000$ i to za skoro $70 \%$ površine. S obzirom da se ova karta radi od 1964. godine, pri korišćenju ovog materijala morao se prilagoditi današnjoj klasifikaciji i nomenklaturi.

- Pedološke karte šumskih površina iz šumskoprivrednih osnova mjerila $1: 10.000$ i $1: 25.000$.

- Podaci Inventure šuma na velikim površinama za ona područja gdje do sada nisu obavljena sistematska pedološka kartiranja.

Kod izrade ove karte, prikaz zemljišnog pokrivača je dat u smislu najnovijeg naučnog gledanja na struk. turu zemljišta, te su izdvojene zemljišne kombinacije tipa mozaik, niz i sl., a samo izuzetno su izdvojeni samostalni zemljišni areali. Ovakav pristup nije bio prisutan kod karata sitnih mjerila.

3.5. Metod izrade Karte realne šumske vegetacije Bosne i Hercegovine (R 1: 200.000)

Za izradu karte korištena su tri izvora: većim dijelom (oko $70 \%$ površine Bosne i Hercegovine) karte realne šumske vegetacije šumsko-privrednih područja, koje su sastavni dio šumsko-privrednih osnova (pretežno karte razmjere $1: 25.000$, a manjim dijelom razmjere 1 : 10.000); drugi izvor bile su pojedine Sekcije Vegetacijske karte Bosne i Hercegovine, koje su radili autori ove studije (unutar projekta »Vegetacijska karta SFRJ, teritorij $\mathrm{BiH} \&$ ) u razmjeri 1: 50.000; za neznatne površine Bosne i Hercegovine za koje nisu postojale vegetacijske karte, korištene su sastojinske karte šumskoprivrednih osnova.

Pri korištenju karata izvršeno je prilagođavanje nomenklature kartografskih jedinica u skladu sa legendom karte predviđenog metoda rada.

Kartografske jedinice su date u legendi karte kao zasebne jedinice, sa izuzetkom kartografskih jedinica označenih kao kompleksi od dvije ili tri vegetacijske jedinice (pretežno termofilna šumska vegetacija kanjona vodotoka).

Unutar odgovarajućih vegetacijskih jedinica simbolima su prikazana nalazišta nekih reliktnih vrsta dendroflore (Picea omorica, Pinus heldreichii, Quercus trojana, Alnus viridis, Castanea vesca) odnosno njihovih fitocenoza.

U publikovanim kartama izostale su neke zajednice specifičnih staništa (npr. zajednice Aceri - Fraxinetum ili Alnetum incanae na karti realne vegetacije). One su doduše, rasprostranjene široko u unutrašnjim područ jima Bosne i Hercegovine sa disperznim arealom, što onemogućava njihovo prikazivanje u razmjeri karte $1: 500.000$.

\subsection{Metod izrade Karte potencijalne vegetacije Bosne i Hercegovine (R 1 : 200.000)}

$\mathrm{Na}$ osnovu sagledavanja vegetacijskih jedinica u Karti realne šumske vegetacije (R 1 : 200.000), njihovog karaktera i uopšte vegetacijskih odnosa, a koristeći Pedološku kartu (R 1 : 200.000) kao i dosadašnja saznanja izrađena je Karta potencijalne vegetacije.

Karta obuhvata vegetacijske jedinice klimazonalnog, klimaregionalnog, ekstrazonalnog, intrazonalnog i azonalnog karaktera, koje su rezultante određene konstalacije stanišnih uslova i ujedno izraz potencijala staništa, bez obzira na izražene stepene antropogenih uticaja. U legendi karte su, iz razumljivih razloga, izostale jedinice sekundarnog karaktera, koje je sadržavala Karta realne šumske vegetacije.

Kartografske jedinice su prikazane kao zasebne jedinice izuzev manjih površina (pretežno kanjoni vodotoka), gdje su prikazane u kompleksima dvije ili tri vegetacijske jedinice. Isti je slučaj i sa dijelom sjeverozapadne Bosne (područje Cazinske Krajine), gdje su 
prikazane kao kompleksi šume kitnjaka i običnog graba, kitnjaka i pitomog kestena (u publikovanoj karti R 1 : 500.000, međutim, šume pitomog kestena prikazane su simbolima).

\section{FITOGEOGRAFSKE I EKOLOŠKE KARAKTE RISTIKE BOSNE I HERCEGOVINE}

Najveći dio teritorije Bosne i Hercegovine pripada eurosibirskoj-sjeveroameričkoj regiji kontinentalnih dijelova, a manji dio mediteranskoj ili sredozemnoj regiji. Samo u najvišim planinskim područjima zastupljena je alpsko-visokonordijska regija, kojoj pripada vegetacija iznad gornje granice šume, ali djelomično travna vegetacija planinskih rudina $i$ vegetacija stijena i točila u pojasu klekovine bora i subalpinskih šuma (HORVATIC, S., 1967).

Ove regije diferenciraju se na niže fitogeografske teritorijalne cjeline - provincije: ilirsku, koja obuhvata zapadne humidnije krajeve, mezijsku, koja obuhvata istočne aridnije krajeve i $\mathrm{srednjo-}$ e vrops ku, kojoj pripadaju najsjeverniji krajevi Bosne i Hercegovine.

U Ilirskoj proviniciji rasprostranjena je klimazonalna zajednica kitnjaka i graba (Querco-Carpinetum) i niz oro-edafskih fitocenoza mezofilno-higrofilnog karaktera. Na njih se nadovezuju zajednice bukovih i mješovitih šuma bukve i jele (sa smrčom) reda Fagetalia u čijem arealu se sreće takođe niz oro-edafskih fitocenoza šumskih zajednica veoma širokog ekološkog raspona, od kserofilnih, preko mezofilnih do higrofilnih šuma.

\subsection{EUROSIBIRSKA - SJEVEROAMERIČKA REGIJA}

4.1.1. Pojas hrastovih šuma nizinskog i brdskog područja ilirske i prelazno ilirske-mezijske provincije

Pored klimazonalne ili klimatogene šume hrasta kitnjaka i graba (Querco-Carpinetum) sveze Carpinion betuli, u ovom pojasu javljaju se acidofolne šume kitnjaka, kao i šume kitnjaka i kestena, sveze Quercion robori-petraeae, zatim higrofilne šume lužnjaka i graba (Carpino betuli - Quercetum roboris), poplavne šume lužnjaka, sveze Alno-Quercion, te šume johe Alnion glutinosae i šume vrba sveze Salicion albae.

Zastupljenost i rasprostranjene ovih šuma rezultat je klimatskih, geomorfoloških i edafskih uslova. Klimatski, ovo su područja umjereno kontinentalne klime sa vrlo povoljnim hidrotermičkim režimom $u$ vegetacionom periodu (Tabela 1 i 3). Geomorfološki, ovaj pojas je vezan u sjevernim krajevima za aluvijalne i diluvijalne terase, koje su dobrim dijelom pokrivene sa beskarbonatnim lesom, kao i za niži brdski pojas.

Zemljišta pod šumom kitnjaka i graba (QuercoCarpinetum) pripadaju pretežno dubokim kambisolima, luvisolima ili pseudogleju, a rjeđe lapornim rendzinama. Na zaravnjenim i blago valovitim terenima na tercijernim sedimentima i diluvijalnim terasama sjeverne Bosne $i$ dublje u unutrašnjosti u dolinama Spreče, Vrbasa, Sane i drugih rasprostranjene su šume lužnjaka i graba (Carpino betuli-Quercetum roboris), koje se bitnije razlikuju od poplavnih šuma lužnjaka (Genisto elatae - Quercetum roboris) na močvarnim oglejenim zemljištima (eugleju).

U sjeverozapadnom, centralnom, istočnom i jugoistočnom dijelu Bosne, gdje su zastupljeni permski pješčari i škriljci, djelomično i verfenski sedimenti zastupljene su, na većim prostranstvima kao oro-edafske zajednice, šume kitnjaka (Quercetum petraeae montanum), sa nizom varijanti - subasocijacija, zavisno od stanišnih, prvenstveno edafskih prilika (nudum, callunetosum, vaccinietosum, itd.), a u istočnim i jugoistočnim krajevima šume kitnjaka i cera (Quercetum petraeae-cerris).

U krajevima sjeveroistočne $\mathrm{i}$ istočne Bosne, na nizu terasa sa vertisolima i eutričnim smeđim zemljištima i distričnim kambisolima na perm-karbonskim stijenama rasprostranjene su šume sladuna i cera (Quercetum confertae - cerris) koje su veoma dobar klimatski indikator daleko suvlje klime (Tabela 2). Iznad ovih šuma $u$ višoj brdskoj zoni zastupljene su šume kitnjaka i cera (Quercetum petraeae-cerris) na nižim i toplijim, a šume kitnjaka (Quercetum petraeae montanum) na višim i hladnijim položajima. Sa njima alterniraju šume bukve neutrofilne varijante (Fagetum montanum) i acidofilne (Luzulo-Fagetum), na hladnijim položajima. Ove posljednje mogu biti i na smeđem podzolastom zemljištu (brunipodzolu).

$\mathrm{Na}$ čitavoj teritoriji ove fitogeografske kategorije rasprostranjene su, kao oro-edafske zajednice, šuma medunca i crnog graba (Querco pubescentis- Ostryetum carpinifoliae) ili šuma crnog jasena i graba (Orno Ostryetum carpinifoliae), a vezane su pretežno za kanjone na krečnjacima i za toplija staništa. Zemljišta pripadaju kalkomelanosolima i kalkokambisolima. Mjestimično se susreću, na najtoplijim staništima u nižoj zoni šume bijelog graba (Carpinetum orientalis), sa kojima su šume cera (Orno-Quercetum cerris), ponegdje, sindinamski povezane (Jadovnik kod Drvara).

U području peridotita i serpentinita sjeverne i istočne Bosne, u najnižoj zoni ispoljavaju se specifični odnosi šumske vegetacije i zemljišta. Na zaravnjenom reljefu koji je pokriven u pleistocenu eolskim nanosi$\mathrm{ma}$, na pseudogleju i distričnom kambisolu rasprostranjene su šume kitnjaka i graba, odnosno lužnjaka i graba, npr. u okolini Teslića na Borji planini, na Javorju, kod Pribinića, na planini Ozren, kod Žepča, kod Svatovca i Turije, nedaleko od Lukavca. Degradacijom prelaze u vrištine (Genisto-Callunetum). Na čistim serpentinitima, gdje je reljef blaži alterniraju šume kitnjaka, koje zauzimaju donje dijelove padina sa dubljim svježijim zemljištima tipa luvisola i pseudogleja, sa šumama bijelog bora na eutričnom kambisolu, šuma. ma crnog bora, koje zauzimaju grebene i strme padine sa rankerom i eutričnim smeđim zemljištem, često plitkim i skeletnim. Posebni slučajevi predstavljaju koluvijalni skeletni nanosi, najčešće sa kitnjakovim šumama ili njihovim degradacionim stadijima, od kojih je karakterističan šibljak ruja (Cotynetum coggygriae). Na kamenjarama i padinama sa litosolom (nerazvijenim zemljištem) rasprostranjena je specifična vegetacija reda Halacsyetalia sendtneri $R t$, sa više serpentinofitskih fitocenoza (RITTER-STUDNICKA 1963). U višegradskom serpentinskom području, zbog relativno malih visina $\mathrm{i}$ uticaja suvlje $\mathrm{i}$ toplije klime mezijske provincije, rasprostranjene su samo kserofilne šume crnog bora na rankerima i eutričnom kambisolu.

4.1.2. Gorski pojas bukve, bukve i jele, bukve i jele sa smrčom i subalpinski pojas bukve (Fagetalia)

Iznad pojasa hrastovih šuma nadovezuje se, prvo gorski, a zatim subalpinski vegetacijski pojas. U tom pojasu su izražene regionalne zajednice: 1 . brdske bukove šume, 2 . šume bukve $i$ jele, 3 . šume bukve i jele sa smrčom i 4. subalpinske bukove šume.

Brdske bukove šume izgrađuju svoj pojas na krečnjačkim planinama u zapadnoj i jugozapadnoj Bosni, gdje se osjećaju mediteranski uticaji klime, dok je $u$ unutrašnjosti ovaj pojas samo mestimično izražen (Karta realne šumske vegetacije). Na silikatnim supstratima, u unutrašnjem i sjevernom dijelu Bosne, bu- 
kove šume se često javljaju u submontanom pojasu kao oro- edafski stadij vegetacije na hladnijim ekspozicijama.

Brdske šume bukve na zemljištima bogatim bazama, sveze Fagion illyricum, degradacijom prelaze, zavisno od reljefa $\mathrm{i}$ zemljišta, $\mathrm{u}$ mezofilne livade reda Arrenetherethalia, ili regresivne stadije šibljačkih zajednica lijeske (Corylion avellanae). Termofilna varijanta bukovih šuma (Seslerio autumnalis - Fagetum, Ostryo - Fagetum, Aceri obtusati - Fagetum), preko različitih šbljačkih zajednica prelaze u kamenjare i kserofilne livade reda Brometalia erecti.

Bukove šume na zemljištima siromašnim bazama, sveze Luzulo-Fagion, najčešce se nalaze na kiselo smeđem zemljištu (distričnom kambisolu), smeđe podzolastom zemljištu (brunipodzolu) i padinskom pseudogleju. Javljaju se u više varijanti - fitocenoza (Luzulo - Fagetum, Blechno - Fagetum, Musco - Fagetum). Njihovom degradacijom nastaju regresivni šibljački stadiji Pteridio - Iuniperetalia i Genisto - Callunetalia, odnosno livade reda Calluno - Ulicetalia i Arrhenetheretalia.

śume bukve i jele - šume bukve i jele bez smrče, kao klimaregionalne šume, rasprostranjene su u područjima gdje se jače osjećaju uticaji mediteran. ske klime u južnijem području Bosne i Hercegovine. One se takođe rasprostiru i u sjevernom pripanonskom području Bosne gdje dolaze do izražaja uticaji panonske klime, odnosno atlanske klime (Karta realne vegetacije). U sjevernom dijelu Bosne one imaju često ostrvski karakter (Kozara, Majevica).

U južnom dijelu areala su najčešće na krečnjačkim zemljištima i odlikuju se sa nizom vrsta neutrofilno-mezofilnog karaktera, dok $\mathrm{u}$ sjevernom dijelu areala one se nalaze na vrlo različitim supstratima $j$ mogu sadržavati znatan broj vrsta prizemne flore acidofilnog karaktera. Ali, i u tom slučaju one nemaju, u sloju drveća, smrču (Picea abies) koja ovdje izostaje zbog klimatskih uticaja. Interesantno je da se ovdje jela (Abies alba) javlja relativno nisko i da se prirodno podmlađuje, mjestimično, i u hrastovom pojasu.

sume bukve i jele sa smrčom diferenciraju se na dvije ekološke serije zajednica: jednu, vezanu za krečnjačka zemljišta i drugu, za kiselo smeđa i opodzoljena zemljišta. Jedna i druga su veoma široko rasprostranjene u Bosni i Hercegovini.

Krečnjačke zajednice su veoma bogate vrstama u prizemnom sloju flore, naročito iz ekološke skupine neutrofilno-mezofilnih vrsta, a rasprostranjene su na seriji krečnjačkih zemljišta koja se odlikuju bogatstvom humusa (tipa mull humusa). Naprotiv, zajednice na zemljištima siromašnim bazama, koja su razvijena na kiselim silikatnim supstratima, oskudnije su vrstama prethodne skupine, a udio acidofilnih elemenata je utoliko veći, ukoliko je supstrat siromašniji bazama. Taj momenat određuje i odnos vrsta lišćara i četinara u ovim šumama. U šumama bukve $i$ jele na peridotitsko-serpentinskim zemljištima, smrča je sastavni elemenat $u$ hladnijem mikroklimatu (pedoklimatu) u svim slučajevima gdje dolazi do bočnog dreniranja vode $\mathrm{i}$ dopunskog vlaženja zemljišta.

Značajno je spomenuti varijantu ovih šuma na diluvijalnim morenskim nanosima (Igman, Treskavica, Zelengora).

Unutar šume bukve i jele sa smrčom nalaze se često različite zajednice kao trajni stadiji, uslovljene edafski i mikroklimatski, kao npr. šuma javora $i$ jasena (Aceri - Fraxinetum) *) na koluvijalnim svježim

-) Zajednica javora i jasena (Aceri - Fraxitetum) je veoma rasprostranjena u Bosni i Hercegovini, ali zbog njenog disperznog areala nije mogla biti prikazana na Karti realne vegetacije. i humusom bogatim zemljištima, te inverzni tipovi smrčevih šuma (Piceetum dolomiticum) oko Kupreškog polja, (Piceetum inversum), na Igmanu. Osim ovih, trajni stadiji smrčevih šuma opisani su na podzolu i pseudogleju oko Nišića i Olova (Lycopodio - Piceetum, Sphagno - Piceetum) i druge.

Posebnu grupu zajednica čine šumske fitocenoze sekundarnog karaktera, šuma bijelog bora i smrče (Piceo - Pinetum illyricum, Piceo - Pinetum silicicolum), šuma smrče i jele (Abieti - Piceetum illyricum, Abieti-Piceetum silicicolum).

$\mathrm{Na}$ serpentinima, u pojasu šuma bukve i jele sa smrčom, rasprostranjene su šume bijelog i crnog bora (Pinetum nigrae-silvestris serpentinicum) kao trajni stadiji, kao i na dolomitu Zapadne Bosne (Pinetum silvestris dolomiticum) i Hercegovine (Pinetum nigrae dolomiticum). Na krečnjačkim zemljištima u ovoj zoni, na grebenima i padinama Romanije, Sjemeča, Zelengore, poznate su šume crnog bora (Pinetum nigrae calcicolum).

Subalpinske šume bukve rasprostranjene su na seriji krečnjačkih, kao i na seriji kiselo smeđih zemljišta. Prve su vezane pretežno za kalkomelanosole (crnice), rjeđe i za luvisole (ilimerizovana zemljišta), odnosno koluvijalna zemljišta i zemljišta na morenama (morenske rendzine); druge su vezane $\mathrm{za}$ rankere $\mathrm{i}$ distrične kambisole, rjeđe za luvisole ili pseudoglej na glinovitim supstratima. Poseban tip ovih šuma je na podzolima i brunipodzolima (na Magliću, Zelengori, Treskavici i drugim nekim planinama).

Unutar pojasa subalpinskih bukovih šuma nalaze se šume smrče (Piceetum subalpinum), također u dvije varijante, $u$ pogledu supstrata $i$ zemljišta.

\section{Pojas,klekovine bora (krivulja)}

Najizraženiji je ovaj pojas na krečnjačkim planinama (Pinetum mugi dinaricum) sa specifičnim florističkim sastavom visokoplaninskih elemenata, gdje je zastupljen niz endema i reliknih vrsta poznatih također i u visokoplaninskoj travnoj vegetaciji i vegetaciji stijena. Na Vranici, unutar pojasa klekovine bora (Pinetum mugi) i subalpinske šume bukve (Vaccinio - Fagetum) zastupljena je zajednica zelene johe (Athyrio Alnetum viridis) na rankeru i distričnom kambisolu.

\subsection{MEDITERANSKA REGIJA}

Južni dio Bosne i Hercegovine pripada mediteranskoj regiji Jadranske provincije koja se, klimatski i fitogeografski, diferencira na eumediteransku zonu zimzelene vegetacije, sveze Quercion ilicis, vrlo ograničenog areala, dok znatno veća prostranstva zauzima submediteranska zona i mediteransko montani pojas listopadne vegetacije, sveze Ostryo - Carpinion.

4.2.1. Eumediteranska zona zimzelene vegetacije sveze Quercion ilicis

Obuhvata usko područje oko Neuma koje se visinski prostire do $350 \mathrm{~m}$ n. v., a u kojem dominiraju krečnjaci sa mozaikom zemljišta tipa kalkomelanosola, terra rosse, lapornih rendzina na flišu. Vegetaciju predstavljaju degradacioni stadiji šume crnike (Orno Quercetum ilicis), makija i garig, sa više zajednica reda Cisto - Ericetalia koje odražavaju stepen erodiranosti zemljišta.

4.2.2. Submediterenska zona i mediteransko montani pojas listopadne vegetacije sveze Ostryo - Carpinion

Niža submediteranska zona karakteriše se šumskom zajednicom Carpinetum orientalis, sveze Ostryo - Carpinion, reda termofilnih šuma hrasta medunca Quercetalia pubescentis. Rasprostranjena je na plitkim 
prikazane kao kompleksi šume kitnjaka i običnog graba, kitnjaka i pitomog kestena (u publikovanoj karti R 1 : 500.000, međutim, šume pitomog kestena prikazane su simbolima).

\section{FITOGEOGRAFSKE I EKOLOSKE KARAKTE- RISTIKE BOSNE I HERCEGOVINE}

Najveći dio teritorije Bosne i Hercegovine pripada eurosibirskoj-sjeveroameričkoj regiji kontinentalnih dijelova, a manji dio mediteranskoj ili sredozemnoj regiji. Samo u najvišim planinskim područjima zastupljena je alpsko-visokonordijska regija, kojoj pripada vegetacija iznad gornje granice šume, ali djelomično i travna vegetacija planinskih rudina $i$ vegetacija stijena i točila u pojasu klekovine bora i subalpinskih šuma (HORVATIC, S., 1967).

Ove regije diferenciraju se na niže fitogeografske teritorijalne cjeline - provincije: ilirsku, koja obuhvata zapadne humidnije krajeve, mezijsku, koja obuhvata istočne aridnije krajeve i srednjoe v rop s ku, kojoj pripadaju najsjeverniji krajevi Bosne i Hercegovine.

U Ilirskoj proviniciji rasprostranjena je klimazonalna zajednica kitnjaka i graba (Querco-Carpinetum) i niz oro-edafskih fitocenoza mezofilno-higrofilnog karaktera. Na njih se nadovezuju zajednice bukovih mješovitih šuma bukve i jele (sa smrčom) reda Fage talia u čijem arealu se sreće takođe niz oro-edafskih fitocenoza šumskih zajednica veoma širokog ekološkog raspona, od kserofilnih, preko mezofilnih do higrofilnih šuma.

\subsection{EUROSIBIRSKA - SJEVEROAMERIČKA REGIJA}

4.1.1. Pojas hrastovih šuma nizinskog i brdskog područja ilirske i prelazno ilirske-mezijske provincije

Pored klimazonalne ili klimatogene šume hrasta kitnjaka i graba (Querco-Carpinetum) sveze Carpinion betuli, $\mathrm{u}$ ovom pojasu javljaju se acidofolne šume kitnjaka, kao i šume kitnjaka i kestena, sveze Quercion robori-petraeae, zatim higrofilne šume lužnjaka i graba (Carpino betuli - Quercetum roboris), poplavne šume lužnjaka, sveze Alno-Quercion, te šume johe Alnion glutinosae i šume vrba sveze Salicion albae.

Zastupljenost i rasprostranjene ovih šuma rezultat je klimatskih, geomorfoloških i edafskih uslova. Klimatski, ovo su područja umjereno kontinentalne klime sa vrlo povoljnim hidrotermičkim režimom $\mathrm{u}$ vegeta cionom periodu (Tabela 1 i 3). Geomorfološki, ovaj pojas je vezan u sjevernim krajevima za aluvijalne i diluvijalne terase, koje su dobrim dijelom pokrivene sa beskarbonatnim lesom, kao i za niži brdski pojas.

Zemljišta pod šumom kitnjaka i graba (QuercoCarpinetum) pripadaju pretežno dubokim kambisolima, luvisolima ili pseudogleju, a rjeđe lapornim rendzinama. Na zaravnjenim i blago valovitim terenima na tercijernim sedimentima i diluvijalnim terasama sjeverne Bosne $\mathrm{i}$ dublje u unutrašnjosti u dolinama Spreče, Vrbasa, Sane i drugih rasprostranjene su šume lužnjaka i graba (Carpino betuli-Quercetum roboris), koje se bitnije razlikuju od poplavnih šuma lužnjaka (Genisto elatae - Quercetum roboris) na močvarnim oglejenim zemljištima (eugleju).

U sjeverozapadnom, centralnom, istočnom i jugoistočnom dijelu Bosne, gdje su zastupljeni permski pješčari i škriljci, djelomično i verfenski sedimenti zastupljene su, na većim prostranstvima kao oro-edafske zajednice, šume kitnjaka (Quercetum petraeae montanum), sa nizom varijanti - subasocijacija, zavisno od stanišnih, prvenstveno edafskih prilika (nudum, callunetosum, vaccinietosum, itd.), a $\mathbf{u}$ istočnim i jugoistočnim krajevima šume kitnjaka i cera (Quercetum petraeae-cerris).

U krajevima sjeveroistočne $\mathrm{i}$ istočne Bosne, na nizu terasa sa vertisolima i eutričnim smeđim zemljištima i distričnim kambisolima na perm-karbonskim stijenama rasprostranjene su šume sladuna $\mathrm{i}$ cera (Quercetum confertae - cerris) koje su veoma dobar klimatski indikator daleko suvlje klime (Tabela 2). Iznad ovih šuma u višoj brdskoj zoni zastupljene su šume kitnjaka i cera (Quercetum petraeae-cerris) na nižim i toplijim, a šume kitnjaka (Quercetum petraeae montanum) na višim i hladnijim položajima. Sa njima alterniraju šume bukve neutrofilne varijante (Fagetum montanum) i acidofilne (Luzulo-Fagetum), na hladnijim položajima. Ove posljednje mogu biti i na smeđem podzolastom zemljištu (brunipodzolu).

$\mathrm{Na}$ čitavoj teritoriji ove fitogeografske kategorije rasprostranjene su, kao oro-edafske zajednice, šuma medunca i crnog graba (Querco pubescentis- Ostryetum carpinifoliae) ili šuma crnog jasena i graba (Orno Ostryetum carpinifoliae), a vezane su pretežno za kanjone na krečnjacima i za toplija staništa. Zemljišta pripadaju kalkomelanosolima i kalkokambisolima, Mjestimično se susreću, na najtoplijim staništima u nižoj zoni šume bijelog graba (Carpinetum orientalis), sa kojima su šume cera (Orno-Quercetum cerris), ponegdje, sindinamski povezane (Jadovnik kod Drvara).

U području peridotita i serpentinita sjeverne istočne Bosne, u najnižoj zoni ispoljavaju se specifični odnosi šumske vegetacije i zemljišta. Na zaravnjenom reljefu koji je pokriven u pleistocenu eolskim nanosima, na pseudogleju i distričnom kambisolu rasprostranjene su šume kitnjaka i graba, odnosno lužnjaka i graba, npr. u okolini Teslića na Borji planini, na Javorju, kod Pribinića, na planini Ozren, kod Žepča, kod Svatovca i Turije, nedaleko od Lukavca. Degradacijom prelaze u vrištine (Genisto-Callunetum). Na čistim serpentinitima, gdje je reljef blaži alterniraju šume kitnjaka, koje zauzimaju donje dijelove padina sa dubljim svježijim zemljištima tipa luvisola i pseudogleja, sa šumama bijelog bora na eutričnom kambisolu, šumama crnog bora, koje zauzimaju grebene i strme padine sa rankerom i eutričnim smeđim zemljištem, često plitkim i skeletnim. Posebni slučajevi predstavljaju koluvijalni skeletni nanosi, najčešće sa kitnjakovim šumama ili njihovim degradacionim stadijima, od kojih je karakterističan šibljak ruja (Cotynetum coggygriae). Na kamenjarama i padinama sa litosolom (nerazvijenim zemljištem) rasprostranjena je specifična vegetacija reda Halacsyetalia sendtneri $R t$, sa više serpentinofitskih fitocenoza (RITTER-STUDNICKA 1963). U višegradskom serpentinskom području, zbog relativno malih visina i uticaja suvlje i toplije klime mezijske provincije, rasprostranjene su samo kserofilne šume crnog bora na rankerima i eutričnom kambisolu.

4.1.2. Gorski pojas bukve, bukve i jele, bukve i jele sa smrčom i subalpinski pojas bukve (Fagetalia)

Iznad pojasa hrastovih šuma nadovezuje se, prvo gorski, a zatim subalpinski vegetacijski pojas. U tom pojasu su izražene regionalne zajednice: 1 . brdske bukove šume, 2 . šume bukve $i$ jele, 3 . šume bukve $i$ jele sa smrčom i 4 . subalpinske bukove šume.

Brdske bukove šume izgrađuju svoj pojas na krečnjačkim planinama u zapadnoj i jugozapadnoj Bosni, gdje se osjećaju mediteranski uticaji klime, dok je u unutrašnjosti ovaj pojas samo mestimično izražen (Karta realne šumske vegetacije). $\mathrm{Na}$ silikatnim supstratima, u unutrašnjem i sjevernom dijelu Bosne, bu- 
kove šume se često javljaju u -submontanom pojasu kao oro- edafski stadij vegetacije na hladnijim ekspozicijama.

Brdské šume bukve na zemljištima bogatim bazama, sveze Fagion illyricum, degradacijom prelaze, zavisno od reljefa i zemljišta, $u$ mezofilne livade reda Arrenetherethalia, ili regresivne stadije šibljačkih zajednica lijeske (Corylion avellanae). Termofilna varijanta bukovih šuma (Seslerio autumnalis - Fagetum, Ostryo - Fagetum, Aceri obtusati - Fagetum), preko različitih šibljačkih zajednica prelaze u kamenjare j kserofilne livade reda Brometalia erecti.

Bukove šume na zemljištima siromašnim bazama, sveze Luzulo- Fagion, najčešće se nalaze na kiselo smeđem zemljištu (distričnom kambisolu), smeđe podzolastom zemljištu (brunipodzolu) i padinskom pseudogleju. Javljaju se u više varijanti - fitocenoza (Luzulo - Fagetum, Blechno - Fagetum, Musco - Fagetum). Njihovom degradacijom nastaju regresivni šibljački stadiji Pteridio - Juniperetalia i Genisto - Callunetalia, odnosno livade reda Calluno - Ulicetalia i Arrhenet. heretalia.

sume bukve i jele - šume bukve i jele bez smrče, kao klimaregionalne šume, rasprostranjene su u područjima gdje se jače osjećaju uticaji mediteranske klime $u$ južnijem području Bosne i Hercegovine. One se takođe rasprostiru i u sjevernom pripanonskom području Bosne gdje dolaze do izražaja uticaji panonske klime, odnosno atlanske klime (Karta realne vegetacije). U sjevernom dijelu Bosne one imaju često ostrvski karakter (Kozara, Majevica).

U južnom dijelu areala su najčešće na krečnjačkim zemljištima i odlikuju se sa nizom vrsta neutrofilno-mezofilnog karaktera, dok u sjevernom dijelu areala one se nalaze na vrlo različitim supstratima i mogu sadržavati znatan broj vrsta prizemne flore acidofilnog karaktera. Ali, i u tom slučaju one nemaju, u sloju drveća, smrču (Picea abies) koja ovdje izostaje zbog klimatskih uticaja. Interesantno je da se ovdje jela (Abies alba) javlja relativno nisko i da se prirodno podmlađuje, mjestimično, i u hrastovom pojasu.

sume bukve i jele sa smrčom diferenciraju se na dvije ekološke serije zajednica: jednu, vezanu za krečnjačka zemljišta i drugu, za kiselo smeđa $\mathrm{i}$ opodzoljena zemljišta. Jedna $\mathrm{i}$ druga su veoma široko rasprostranjene u Bosni i Hercegovini.

Krečnjačke zajednice su veoma bogate vrstama u prizemnom sloju flore, naročito iz ekološke skupine neutrofilno-mezofilnih vrsta, a rasprostranjene su na seriji krečnjačkih zemljišta koja se odlikuju bogatstvom humusa (tipa mull humusa). Naprotiv, zajednice na zemljištima siromašnim bazama, koja su razvijena na kiselim silikatnim supstratima, oskudnije su vrstama prethodne skupine, a udio acidofilnih elemenata je utoliko veći, ukoliko je supstrat siromašniji bazama. Taj momenat određuje i odnos vrsta lišćara i četinara u ovim šumama. U šumama bukve $i$ jele na peridotitsko-serpentinskim zemljištima, smrča je sastavni elemenat u hladnijem mikroklimatu (pedoklimatu) u svim slučajevima gdje dolazi do bočnog dreniranja vode i dopunskog vlaženja zemljišta.

Značajno je spomenuti varijantu ovih šuma na diluvijalnim morenskim nanosima (Igman, Treskavica, Zelengora).

Unutar šume bukve i jele sa smrčom nalaze se često različite zajednice kao trajni stadiji, uslovljene edafski i mikroklimatski, kao npr. šuma javora i jasena $($ Aceri - Fraxinetum) *) na koluvijalnim svježim

") Zajednica javora i jasena (Aceri - Fraxinetum) je veoma rasprostranjena u Bosni i Hercegovini, ali zbog nje. nog disperznog areala nije mogla biti prikazana na Karti realne vegetacije. i humusom bogatim zemljištima, te inverzni tipovi smrčevih šuma (Piceetum dolomiticum) oko Kupreškog polja, (Piceetum inversum), na Igmanu. Osim ovih, trajni stadiji smrčevih šuma opisani su na podzolu i pseudogleju oko Nišića i Olova (Lycopodio - Piceetum, Sphagno - Piceetum) i druge.

Posebnu grupu zajednica čine šumske fitocenoze sekundarnog karaktera, šuma bijelog bora i smrče (Piceo - Pinetum illyricum, Piceo - Pinetum silicicolum), šuma smrče i jele (Abieti - Piceetum illyricum, Abieti-Piceetum silicicolum).

$\mathrm{Na}$ serpentinima, u pojasu šuma bukve i jele sa smrčom, rasprostranjene su šume bijelog i crnog bora (Pinetum nigrae-silvestris serpentinicum) kao trajni stadiji, kao i na dolomitu Zapadne Bosne (Pinetum silvestris dolomiticum) i Hercegovine (Pinetum nigrae dolomiticum). Na krečnjačkim zemljištima u ovoj zoni, na grebenima i padinama Romanije, Sjemeča, Zelengore, poznate su šume ornog bora (Pinetum nigrae calcicolum).

Subalpinske šume bukve rasprostranjene su na seriji krečnjačkih, kao i na seriji kiselo smeđih zemljišta. Prve su vezane pretežno za kalkomelanosole (crnice), rjeđe i za luvisole (ilimerizovana zemljišta), odnosno koluvijalna zemljišta i zemljišta na morenama (morenske rendzine); druge su vezane za rankere i distrične kambisole, rjeđe za luvisole ili pseudoglej na glinovitim supstratima. Poseban tip ovih šuma je na podzolima i brunipodzolima (na Magliću, Zelengori, Treskavici i drugim nekim planinama).

Unutar pojasa subalpinskih bukovih šuma nalaze se šume smrče (Piceetum subalpinum), također u dvije varijante, $u$ pogledu supstrata $i$ zemljišta.

Pojas , klekovine bora (krivulja)

Najizraženiji je ovaj pojas na krečnjačkim planinama (Pinetum mugi dinaricum) sa specifičnim florističkim sastavom visokoplaninskih elemenata, gdje je zastupljen niz endema i reliknih vrsta poznatih također i u visokoplaninskoj travnoj vegetaciji i vegetaciji stijena. Na Vranici, unutar pojasa klekovine bora (Pinetum mugi) i subalpinske šume bukve (Vaccinio - Fagetum) zastupljena je zajednica zelene johe (Athyrio Alnetum viridis) na rankeru i distričnom kambisolu.

\subsection{MEDITERANSKA REGIJA}

Južni dio Bosne i Hercegovine pripada mediteranskoj regiji Jadranske provincije koja se, klimatski i fitogeografski, diferencira na eumediteransku zonu zimzelene vegetacije, sveze Quercion ilicis, vrlo ograničenog areala, dok znatno veća prostranstva zauzima submediteranska zona i mediteransko montani pojas listopadne vegetacije, sveze Ostryo - Carpinion.

\subsubsection{Eumediteranska zona zimzelene vegetacije} sveze Quercion ilicis

Obuhvata usko područje oko Neuma koje se visinski prostire do $350 \mathrm{~m} \mathrm{n}$. v., a u kojem dominiraju krečnjaci sa mozaikom zemljišta tipa kalkomelanosola, terra rosse, lapornih rendzina na flišu. Vegetaciju predstavljaju degradacioni stadiji šume crnike (Orno Quercetum ilicis), makija i garig, sa više zajednica reda Cisto - Ericetalia koje odražavaju stepen erodiranosti zemljišta.

4.2.2. Submediterenska zona i mediteransko montani pojas listopadne vegetacije sveze Ostryo - Carpinion

Niža submediteranska zona karakteriše se šumskom zajednicom Carpinetum orientalis, sveze Ostryo -Carpinion, reda termofilnih šuma hrasta medunca Quercetalia pubescentis. Rasprostranjena je na plitkim 


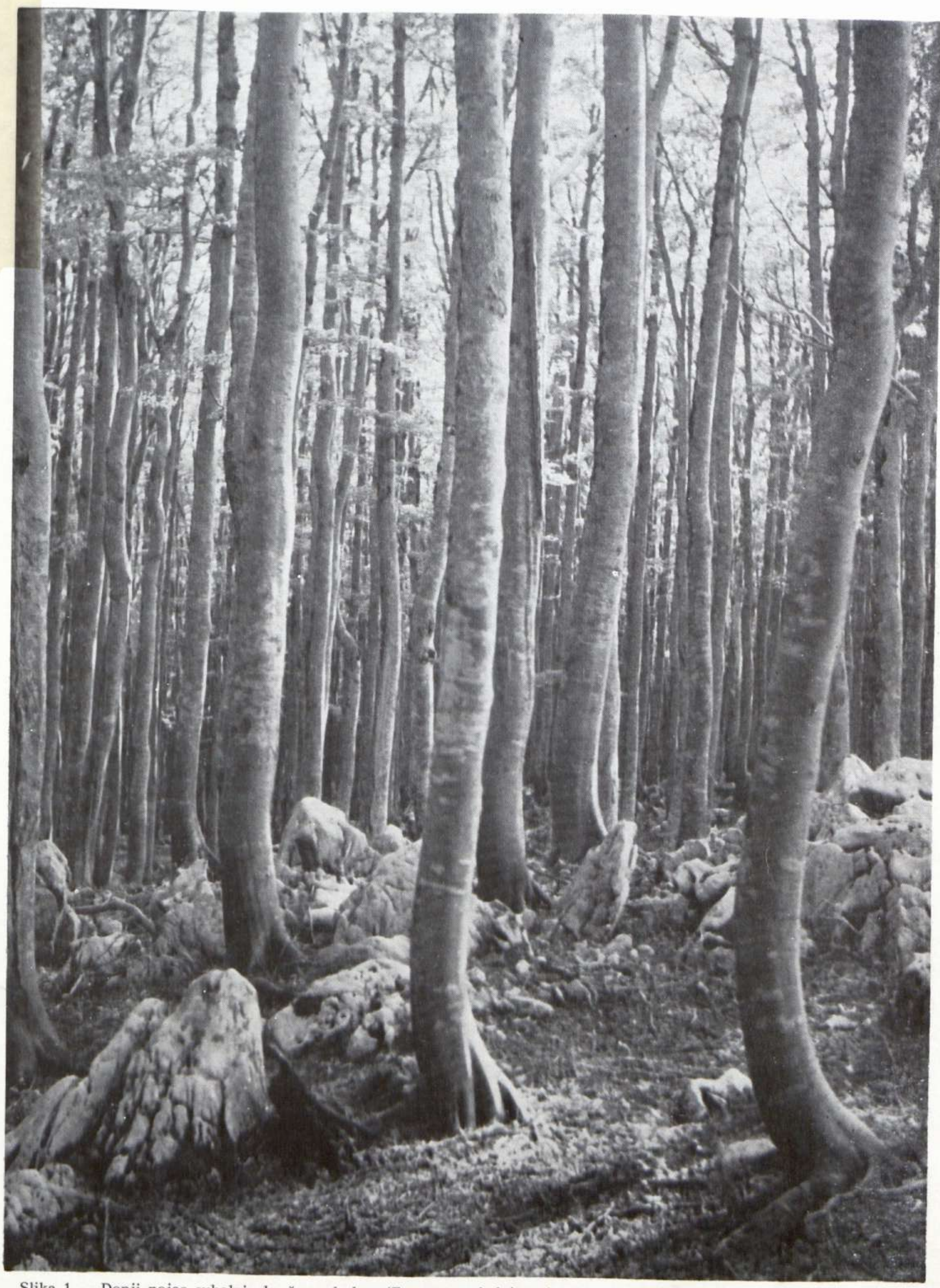

Slika 1 - Donji pojas subalpinske šume bukve (Fagetum subalpinum) na krečnjacima Šator planine (foto č. Silić)

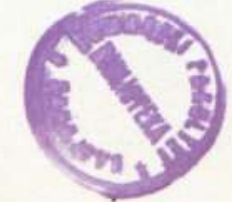



krečnjačkim zemljištima: kalkomelanosolima, kalkokambisolima i terra rossi. Ima niz geografskih varijanti u vidu degradacionih stadija, od niskih šuma, preko šikara, šibljaka do suhih travnjaka i kamenjarskih pašnjaka reda Scorsonero - Chrysopogonetalia (HORVATIC, S. 1967).

$\mathrm{U}$ zoni zajednice Carpinetum orientalis razvijena je, ponegdje na dubljim zemljištima, tipa luvisola i terra rosse, zajednica sladuna i cera (Quercetum confertae adriaticum), kao i fitocenoza cera (Orno - Quercetum cerris) u montanom pojasu Hercegovine na skeletnim krečnjačkim zemljištima. U nižoj zoni šume bijelog graba javlja se zajednica makedonskog hrasta (Quercetum trojanae).

U višem mediteransko montanom pojasu karakteristična je zajednica Seslerio - Ostryetum carpinifoliae na koju se nadovezuje pojas primorske šume bukve Seslerio - Fagetum. U nekim planinama, kao npr. na Gatačkoj Bjelašnici, Nevesinjskoj Crnoj Gori, javlja se i pojas bukve $i$ jele bez smrče na krečnjačkim zemljištima, koja su često erodirana. Na blokovima krečnjaka poznata je zajednica jele Rhamno - Abietetum.

U slivu Neretve, u kanjonima rasprostranjene su i neke reliktne zajednice, kao npr. zajednica javora $i$ lipa (Aceri - Tilietum mixtum), oraha i medvjeđe lijeske (Juglando - Coryletum), munike (Pinetum heldreichii), crnog bora (Pinetum nigrae submediterraneum) i druge, a nalaze se na kalkomelanosolima, koluvijumima ili na dolomitnim rendzinama.

U kraškim poljima koja su plavljena, kao npr. Livanjsko polje, Podrašničko polje, razvijene su zajednice reda Alno - Quercetalia i Alnetalia na eugleju, zatim zajednice redova Populetalia, Molinetalia, Phragmitetalia, što daje posebno fitogeografsko obilježje ovom dijelu Bosne i Hercegovine. 


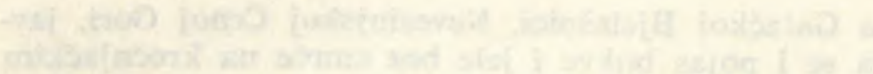
(1)

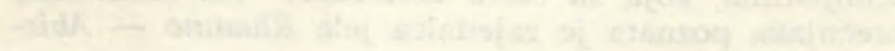

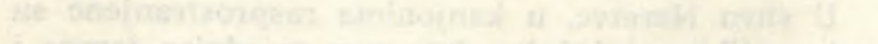

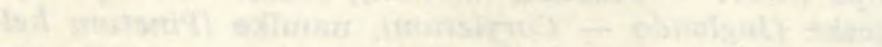

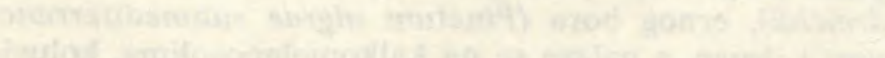

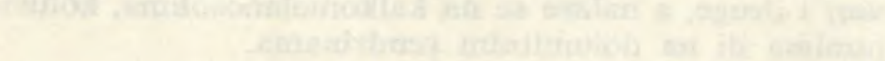

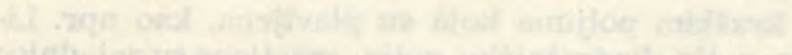

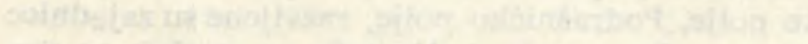

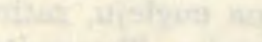

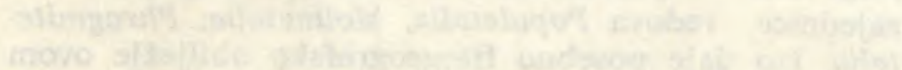

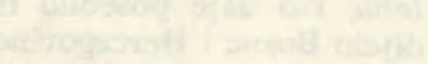




\section{P O S E B N I D I O}

\section{PREGLED EKOLOSKKO-VEGETACIJSKIH REJONA BOSNE I HERCEGOVINE}

Materija koja se obrađuje u posebnom dijelu ove studije sintetizovana je u Pregledu ekološko-vegetacijskih rejona Bosne i Hercegovine. Isticanjem ovog Pregleda u prvi plan željeli smo postići to, da se odmah stekne realna predstava o izvršenoj ekološko-vegetacijskoj rejonizaciji šuma na cjeline - oblasti, kao najšire kategorije preko područja do rejona, odnosno jedinica koje, u stvari, predstavljaju objekte od praktičnog značaja za uzgojno-sjemensku rejonizaciju Bosne i Hercegovine.

U izloženom Pregledu ekološko-vegetacijskih rejona jedinice su numerički označene, s tim što oblasti kao najšire kategorije imaju jednocifreni broj. U oblasti su uvrštena odgovarajuća područja, a u njih odgovarajući rejoni. Iste oznake sadržane su u Karti ekološko-vegetacijskih rejona, a primijenjena je decimalna klasifikacija, pa se prvi broj odnosi na oblast, drugi na područje, a treći na rejon.

$\mathrm{Za}$ sve kategorije, koje obuhvata legenda Karte ekološko-vegetacijskih rejona Bosne i Hercegovine, dat je jednoobrazno komentar navodeći najznačajnije pokazatelje: položaj, klima, geomorfologija i geološka građa, zemljišta, fitogeografska pripadnost, kada su u pitanju oblasti, odnosno karakteristike realne $i$ potencijalne šumske vegetacije, kada su u pitanju područja i rejoni.

\section{EKOLOŠKO-VEGETACIJSKI REJONI}

BOSNE I HERCEGOVINE

Oblast Područje Rejon

\begin{tabular}{lll}
\hline 1 PRIPANONSKA & $\frac{1 \text { SJEVEROBOSANSKO }}{2 \text { SJEVEROZAPADNO BOSANSKO }}$ \\
\cline { 2 - 3 } $\begin{array}{l}2 \text { PRELAZNO } \\
\text { ILIRSKO-MEZIJSKA }\end{array}$ & 1 DONJE DRINSKO \\
\hline
\end{tabular}

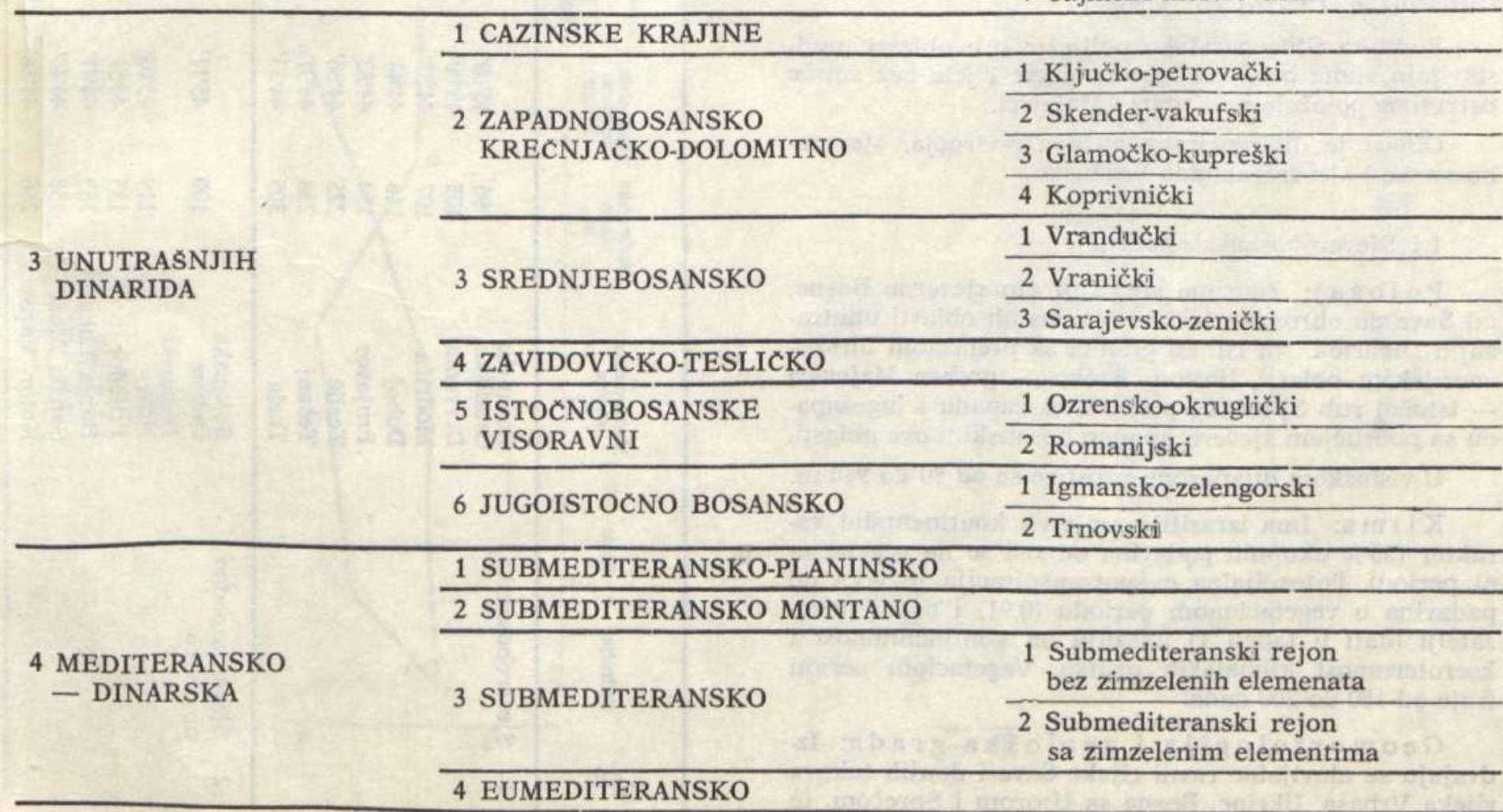




\section{PRIPANONSKA OBLAST}

P o l a ž a j: Ravničarski i brežuljkasti predjeli sjeverne Bosne, od Save i Une prema jugu do oboda brdsko-planinskih masiva oblasti unutrašnjih Dinarida. Dolinama rijeka Sane, Vrbanje, Bosne sa Usorom i Sprečom proteže se dublje u unutrašnjost.

Prema orografskim karakteristikama pripada nizinskom i brdskom pojasu, od 80 do $980 \mathrm{~m}$ nadmorske visine.

K li ma: Ova oblast karakteriše se klimom u kojoj dominiraju kontinentalni klimatski uticaji dok su u krajnjem sjeverozapadnom dijelu oblasti izraženi uticaji atlanske klime. Zato je istočni dio oblasti topliji i sa manje padavina $u$ vegetacionom periodu (premda od ukupnih padavina ima više od $50 \%$ ), od zapadnog dijela oblasti koja je hladnija i sa više padavina u vegetacionom periodu (tabela 1 i grafikoni 1 i 2 ).

Geomorfologija i geološka građa: Geomorfološki predstavlja najniźe aluvijalno-deluvijalne ravni, terase riječnih tokova i jezerskih sedimenata, koje su dobrim dijelom prekrivene beskarbonatnim lesom. Ovim je određen petrografski sastav (najčešće su to gline, pijesci, šljunkovi). Mjestimično su sedimenti flišolikog karaktera vezani za uzdignutije dijelove reljefa, koji su uslovljeni čvnstim magmatskim stijenama.

Z e m 1 ji šta: Zemljišta su uglavnom duboka, težeg mehaničkog sastava, pod uticajem podzemnih i površinskih voda, tako da pripadaju pretežno odjelu hidromorfnih zemljišta.

Fitogeografska pripadnost: Oblast po svojim fitogeografskim karakteristikama, predstavlja pripanonski sektor srednjoevropske provincije koju pretežno karakterišu hrastove nizinske šume sveza Carpinion betuli, Alno-Quercion, Alnion glutinosae, Salicion albae, te šume sveze Quercion robori-petraeae.

Zapadne dijelove oblasti karakteriše prisustvo atlanskih flornih elemenata (kesten - Castanea vesca, vrišt - Calluna vulgaris). Istočni predjeli oblasti imaju zastupljene pontske i pontsko-mezijske florne elemente (Tilia tomentosa, Quercus cerris, Prunus mahaleb, Lathyrus sp., Cytisus sp. i druge).

Posebno fitogeografsko obilježje ove oblasti predstavljaju šume bukve, odnosno bukve $i$ jele bez smrče ostrvskog položaja na Kozari i Majevici.

Oblast je diferenoirana na dva područja: sjeverobosansko i sjeverozapadno bosansko.

\subsection{Sjeverobosansko područje}

Položa j: Zauzima središnji dio sjeverne Bosne, od Save do obronaka brdsko-planinskih oblasti unutrašnjih Dinarida. Na istoku graniči sa prelaznom ilirsko-mezijskom oblasti, linijom Brčko - greben Majevica - istočni rub Sprečkog polja, a na zapadu i jugozapadu sa područjem sjeverozapadno bosanskim ove oblasti.

U visinskom dijapazonu prostire se od 80 do $980 \mathrm{~m}$.

Klima: Ima izrazitije umjeren kontinentalni karakter (55\% ukupnih padavina odnosi se na vegetacioni period). Potencijalna evapotranspiracija je veća od padavina $u$ vegetacionom periodu $(0,91)$ i ostali pokazatelji (dati u tabeli 1) ukazuju na kontinentalnost i kserotermnost klimatskih prilika. Vegetacioni period traje od 180 do 200 dana.

Geomorfologija i geološka građa: Izdvajaju se aluvijalne ravni rijeke Save $\mathrm{i}$ donjih tokova rijeka Vrbasa, Ukrine, Bosne sa Usorom i Sprečom, te

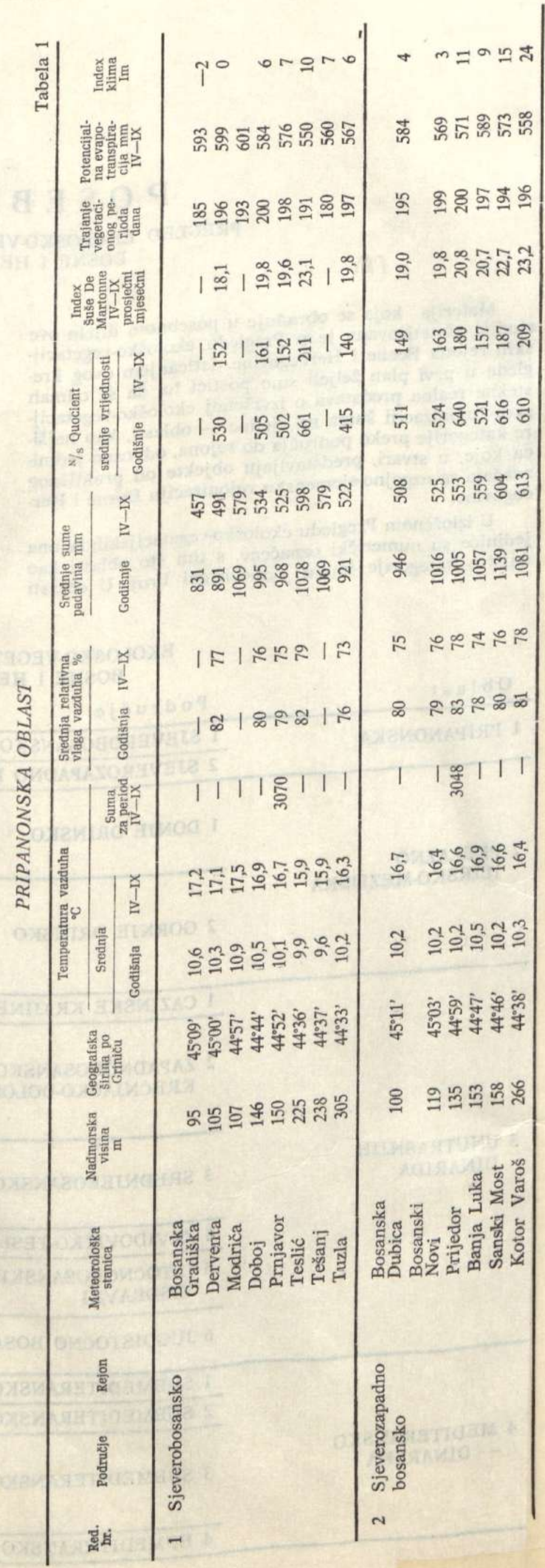



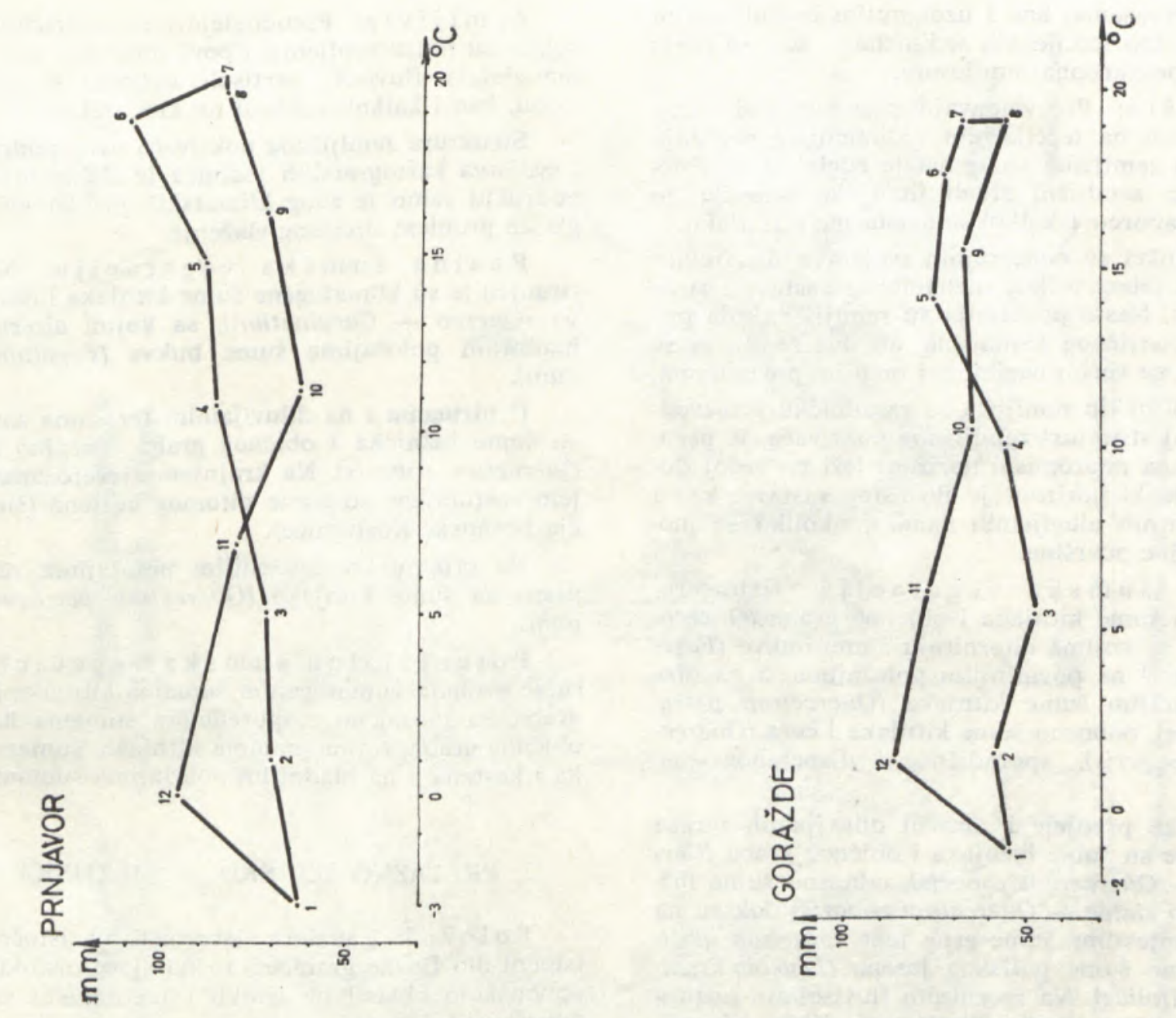

究
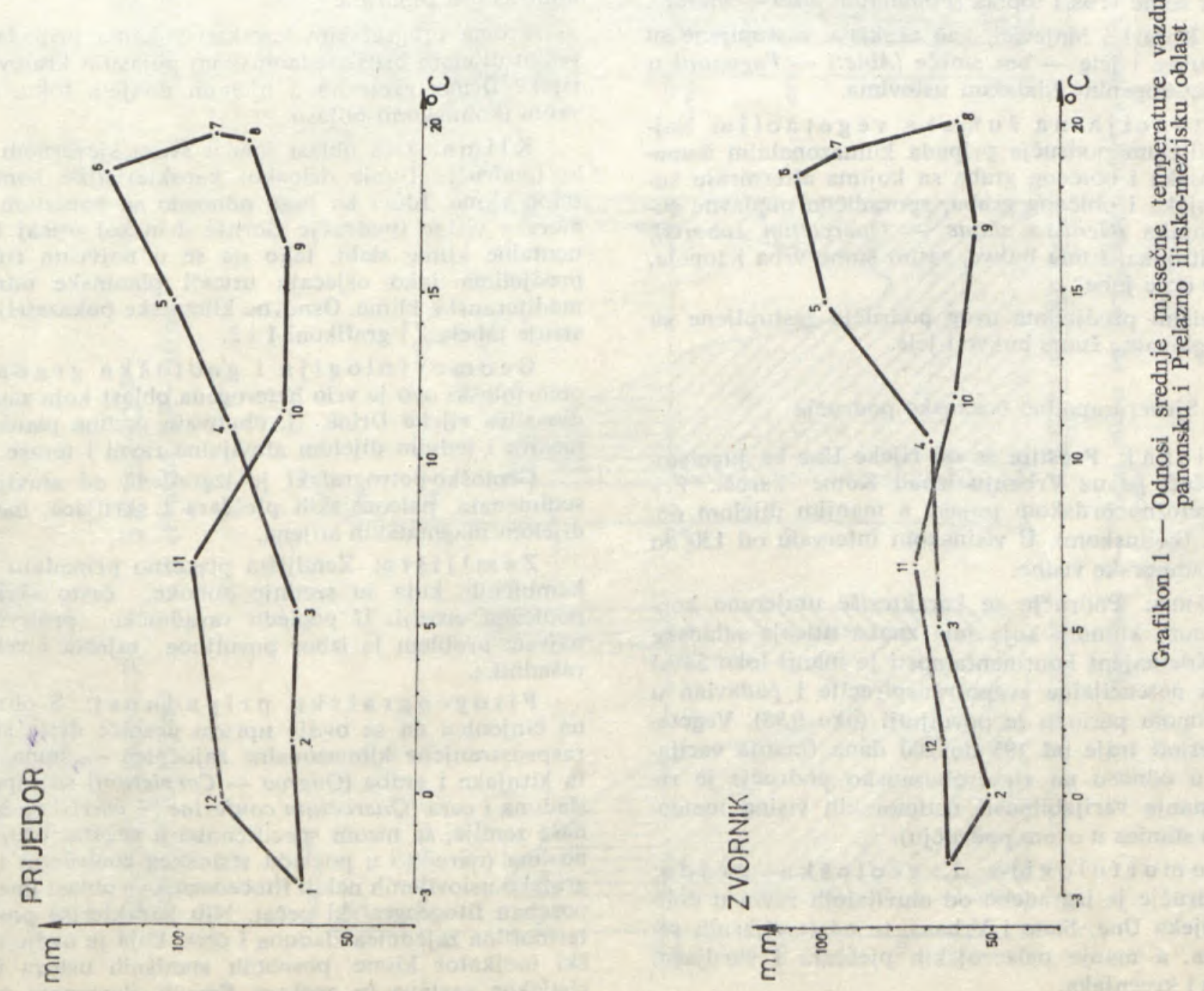
diluvijalnim terasama, kao i uzdignutim brežuljkastim reljefom pretežno tercijernih sedimenata, koji su često pokriveni sa beskarbonatnim lesom.

Zemljišta: Preovladavaju pseudoglejevi i distrični kambisoli na tercijarnim sedimentima a manje zastupljeni su zemljišne kombinacije eugleja i semigleja; samostalni zemljišni areali fluvisola, pelosola, te rendzine na laporcu i kalkokambisola na krečnjaku.

Ova zemljišta su nepovoljnih svojstava, a naročito vodno-fizičkih (zbog teškog mehaničkog sastava i suvišnog vlaženja). Nešto povoljnija su zemljišta, koja pripadaju tipu distričnog kambisola, ali ova zemljišta se javljaju čšće na većim nagibima i manjim površinama.

Najpovoljniji tip zemljišta za rasadničku proizvodnju, u ovakvoj strukturi zemljišnog pokrivača, je pseudoglej kod koga nepropusni horizont leži na većoj dubini, a površinski horizont je ilovastog sastava, kao i fluvisoli recentnih aluvijalnih nanosa, ukoliko se mogu naći dovoljne površine.

Realna šumska vegetacija: Najrasprostranjenije su šume kitnjaka i običnog graba (Querco-Carpinetum) sa kojima alterniraju šume bukve (Fagetum montanum) na povoljnijim položajima, a na orografsko izloženijim šume kitnjaka (Quercetum petra eae montanum), odnosno šume kitnjaka i cera (Quercetum petraeae-cerris), sporadičnog i disperznog rasporeda.

Za nizinske predjele i zaravni diluvijalnih terasa karakteristične su šume lužnjaka i običnog graba (Carpino betuli - Quercetum roboris), odnosno šume lužnjaka (Genisto elatae - Quercetum roboris) dok su na najvlažnijim mjestima šume crne johe (Alnetum glutinosae), odnosno šúme poljskog jasena (Leucoio-Fraxinetum angustifoliae). Na recentnim fluvisolima zastupljene su šume vrba $\mathrm{i}$ topola (Populetum albo - nigrae).

Na Kozari i Majevici, kao eksklave zastupljene su šume bukve i jele - bez smrče (Abieti - Fagetum) u dosta heterogenim edafskim uslovima.

Potencijalna šumska vegetacija: Najvećim dijelom područje pripada klimazonalnim šumama kitnjaka i običnog graba sa kojima alterniraju šume lužnjaka i običnog graba, sporadično poplavne šume lužnjaka (Genisto elatae - Quercetum roboris), šume kitnjaka, šume bukve, zatim šume vrba i topola, te šume crne johe.

U višim predjelima ovog područja zastupljene su klimaregionalne šume bukve i jele.

\subsection{Sjeverozapadno bosansko područje}

Položaj: Prostire se od rijeke Une ka jugoistoku uvlačeći se uz Vrbanju iznad Kotor Varoši. Pripada pretežno brdskom pojasu a manjim dijelom dolinskom (kolinskom). U visinskom intervalu od 130 do $500 \mathrm{~m}$ nadmorske visine.

Klima: Područje se karakteriše umjereno kontinentalnom klimom koja ima znake uticaja atlanske klime. Koeficijent kontinentalnosti je manji (oko 54\%) a odnos potencijalne evapotranspiracije i padavina $u$ vegetacionom periodu je povoljniji (oko 0,98 ). Vegetacioni period traje od 195 do 200 dana (manja varijabilnost $u$ odnosu na sjeverobosansko područje je rezultat manje varijabilnosti nadmorskih visina meteoroloških stanica $u$ ovom području).

Geomorfologija i geološka građa: Ovo područje je izgrađeno od aluvijalnih ravni $u$ dolinama rijeka Une, Sane i Vrbasa, te od tercijarnih sedimenata, a manje paleozojskih pješčara i škriljaca, eruptiva i krečnjaka.
Z emljišta: Pseudoglejevi sa distričnim kambisolom su najzastupljeniji tipovi zemljišta a još dolaze: semiglejevi, fluvisoli, vertisoli, eutrični kambisoli, pelosoli, kao i kalkokambisoli na krečnjaku.

Struktura zemljišnog pokrivača ovog područja, kao i svojstva kartografskih jedinica je slična prethodnom području samo je zbog klimatskih prilika još više naglašen problem suvišnog vlaženja.

Realna šumska vegetacija: Najrasprostranjenije su klimatogene šume kitnjaka i običnog graba (Querco - Carpinetum), sa kojim alterniraju na hladnijim položajima šume bukve (Fagetum montanum).

U nizinama i na diluvijalnim terasama zastupljene su šume lužnjaka i običnog graba (Carpino betuli Quercetum roboris). Na krajnjem sjeverozapadnom dijelu zastupljene su šume pitomog kestena (Šire područje Bosanske Kostajnice).

$\mathrm{Na}$ orografsko izraženijim položajima rasprostranjene su šume kitnjaka (Quercetum petraeae montanum).

Potencijalna šumska vegetacija: Područje pripada klimatogenim šumama kitnjaka i običnog graba, sa mozaično raspoređenim šumama lužnjaka i običnog graba, zatim šumama kitnjaka, šumama kitnjaka i kestena a na hladnijim položajima šumama bukve.

\section{PRELAZNO ILIRSKO - MEZIJSKA OBLAST}

Polož a j: Zauzima sjeveroistočni, istočni i jugoistočni dio Bosne graničeći se na sjeveroistoku, sa Pripanonskom oblasti na istoku i jugozapadu sa oblasti unutrašnjih Dinarida.

Prema orografskim karakteristikama pripada najvećim dijelom brdsko-planinskom pojasu a krajevi oko rijeke Drine, pretežno u njenom donjem toku, nizinskom (kolinskom) pojasu.

Klima: Ova oblast ima u svom sjevernom dijelu (područje Donje drinsko) karakteristike kontinentalne klime. Idući ka jugu odnosno sa porastom nadmorske visine (područje Gornje drinsko) uticaj kontinentalne klime slabi, tako da se u najvišim rubnim predjelima jako osjećaju uticaji planinske odnosno mediteranske klime. Osnovne klimatske pokazatelje ilustruje tabela 2 i grafikoni 1 i 2.

Geomorfologija i geološka građa: Geomorfološki ovo je vrlo heterogena oblast koja zauzima dio sliva rijeke Drine, tj. obuhvata padine planinskih masiva i jednim dijelom aluvijalne ravni i terase.

Geološko-petrografski je izgrađena od aluvijalnih sedimenata, paleozojskih pješćara i škriljaca, manjim dijelom magmatskih stijena.

$\mathrm{Ze} \mathrm{mljišt} \mathrm{a:} \mathrm{Zemljišta} \mathrm{pretežno} \mathrm{pripadaju} \mathrm{klasi}$ kambičnih, koja su srednje duboka, često skeletna, podložna eroziji. U pogledu rasadničke proizvodnje najveći problem je izbor povoljnog mjesta i veličine rasadnika.

Fitogeografska pripadnost: S obzirom na činjenicu da se ovdje upravo graniče dvije široko rasprostranjene klimazonalne zajednice - šuma hrasta kitnjaka i graba (Querco - Carpietum) sa zapada i sladuna i cera (Quercetum confertae - cerris) sa istoka naše zemlje, sa nizom specifičnosti u vegetacijskim odnosima (naročito $u$ pogledu visinskog zoniranja) $i$ orografsko uslovljenih nekih fitocenoza, ova oblast ima svoj poseban fitogeografski pečat. Nju karakteriše posebno termofilna zajednica sladuna i cera, koja je ovdje biološki indikator klime, posebnih stanišnih uslova $i$ florističkog sastava (u spektru flornih elemenata znača- 


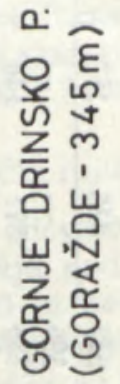

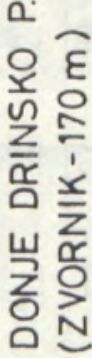
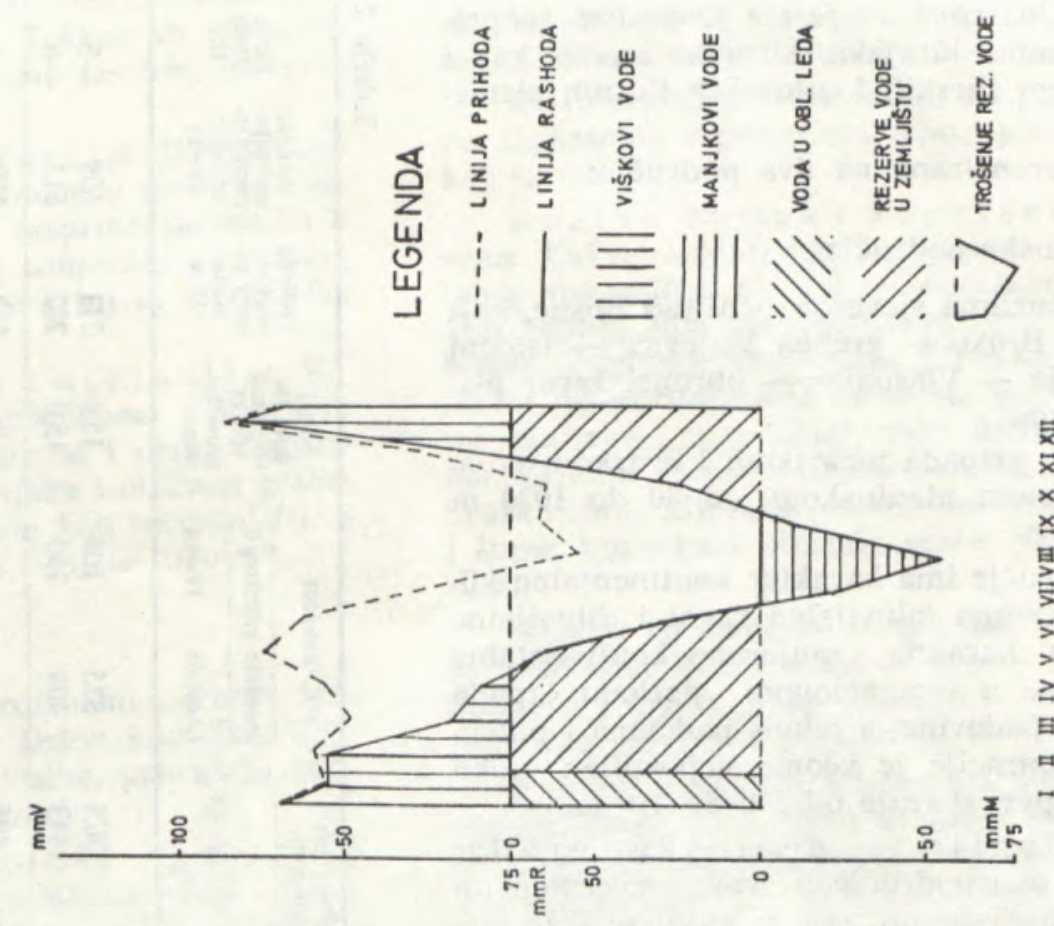

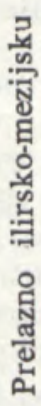

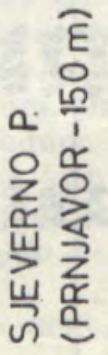

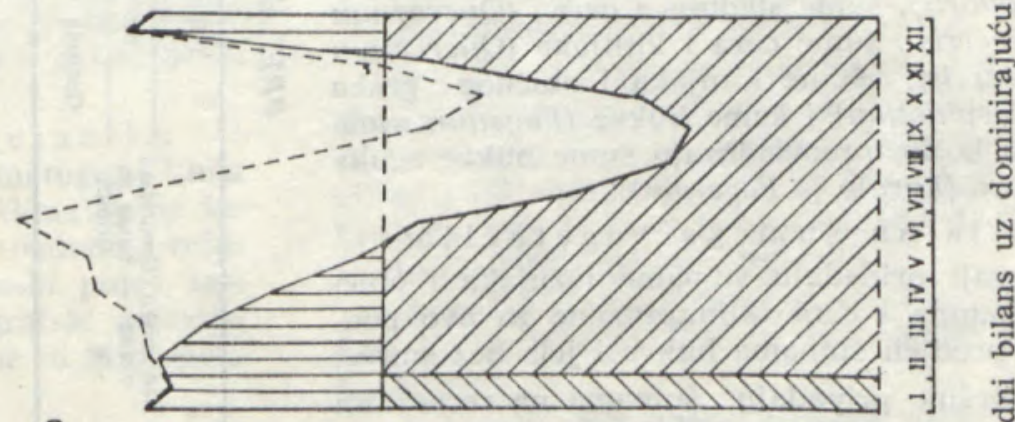

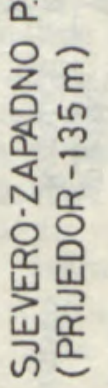

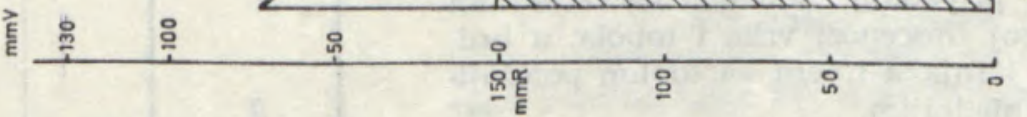

르워ำ

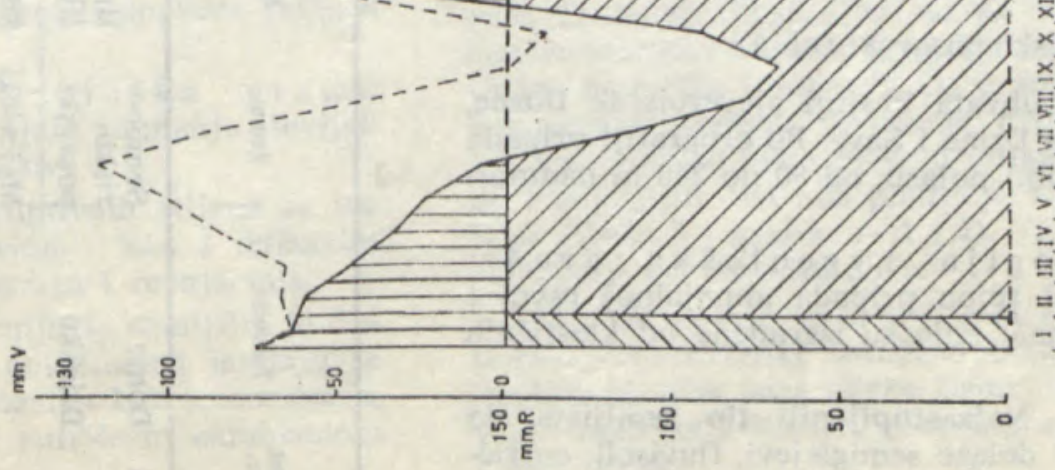


jan udio vrsta: Quercion gonfertae Quercion robori-petraeae), te šumama kitnjaka, kitnjaka i cera, kao i smanjenim učešćem ilirskih i atlanskih flornih elemenata.

Oblast je diferencirana na dva područja:

\subsection{Donje drinsko područje}

Položa j: Zauzima sjeveroistočni dio Bosne, koji ograničava linija: Brčko - greben Majevice - istočni rub Sprečkog polja - Vlasenica - obronci Javor planine - Kanjon Drine.

Većim dijelom pripada nizinskom i brdskom poja$\mathrm{su}$, a manjim-dijelom planinskom, od 80 do $1020 \mathrm{~m}$ nadmorske visine,

K l i ma: Područje ima karakter kontinentalne klime, u nižim dijelovima (aluvijalne ravni i diluvijalne terase), a u višim, karakter umjereno kontinentalne klime. Na padavine u vegetacionom periodu otpada oko $55 \%$ godišnje padavina, a odnos padavina i potencijalne evapotranspiracije je veoma nepovoljan (oko $0,82)$. Vegetacioni period traje od 190 do 210 dana.

Geomorfologija i geološka građa: Geomorfološki se ovo područje u svom sjevernom dijelu karakteriše aluvijalnom ravni u kojoj se diže masiv Majevice. Južno od Zvornika područje prelazi u planinski masiv iznad kanjona Drine.

Izgrađeno je od aluvijalnih sedimenata, eocenskog fliša, andezitsko-dacitskih eruptiva, paleozojskih i trijaskih sedimenata.

$\mathrm{Z}$ e m 1 j i št a: Najzastupljeniji tipovi zemljišta su iz odjela automorfnih $\mathrm{i}$ hidromorfnih, čineći samostalne areale i zemljišne kombinacije. Pojava predstavnika pojedinih odjela vezana je za geomorfološku građu. U nižim predjelima preovladavaju hidromorfna zemljišta, a u višim automorfna, u kojima su najzastupljeniji predstavnici iz kambične klase.

Realna šumska vegetacija: Sumske fitocenoze zadržale su se mozaično u zavisnosti od orografsko-edafskih i antropogenih uticaja. Zastupljene su: šume lužnjaka i običnog graba (Carpino betuli Quercetum roboris), šume sladuna i cera (Quercetum confertae - cerris), šume cera i kitnjaka (Quercetum petraeae - cerris), šume kitnjaka i običnog graba (Querco - Carpinetum) i šume bukve (Fagetum mon. tanum), među kojim preovladavaju šume bukve acidofilnog karaktera (Luzulo - Fagetum).

Potencijalna šumska vegetacija:

Niži položaji pripadaju šumama lužnjaka i običnog graba, sladuna i cera (klimozonalne za ovo područje), a viši predjeli šumama bukve i jele bez smrče.

Manje površine pripadaju šumama na recentnim fluvisolima, azonalnoj fitocenozi vrba i topola, u brdskom pojasu, šumi kitnjaka i cera na toplim položajima, šumi bukve, na hladnijim.

Zaravnjeniji položaji, sa dubljim zemljištima pripadaju šumi kitnjaka $i$ graba.

\subsubsection{Semberijsko-posavski rejon}

Položaj: Obuhvata krajnji sjeveroistok Bosne, između donjeg toka Drine i Save. Po orografiji pripada nizijskom (kolinskom) pojasu, od 80 do $240 \mathrm{~m}$ nadmorske visine.

Geomorfologija i geološka građa: Geomorfološki ovaj rejon pripada aluvijalnoj ravni $i$ diluvijalnim terasama, koje su izgrađene od klastičnih sedimenata.

Z emljišta: Najzastupljeniji tip zemljišta je pseudoglej, a zatim dolaze semiglejevi, fluvisoli, eutrični kambisoli i vertisoli.

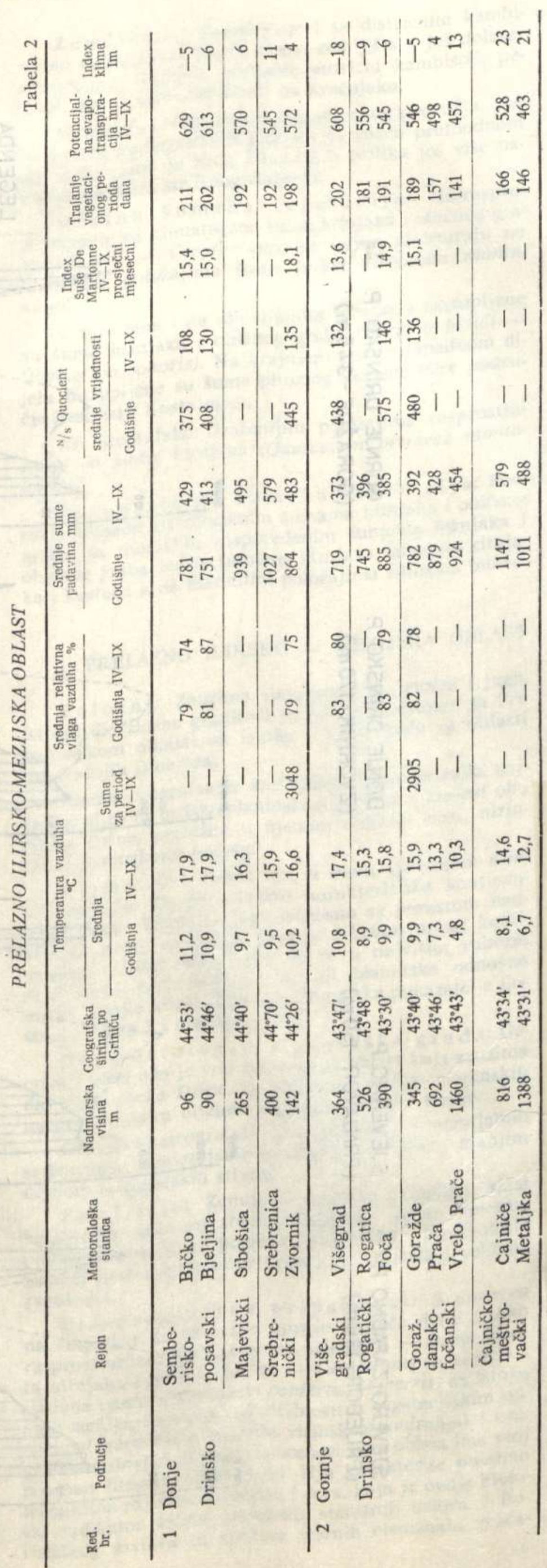


Većim dijelom ovo su zemljišta nepovoljnih svojstava za rasadničku proizvodnju. Teškog su mehaničkog sastava, suviše vlažna, povremeno zasićena podzemnom ili površinskom vodom.

Realna šumska vegetacija: Dominirajuća fitocenoza - šuma lužnjaka i običnog graba (Carpino betuli - Quercetum roboris); rasprostranjene su i: šume sladuna i cera (Quercetum confertae - cerris), šume vrba (Salicetum) i šume crne i bijele topole (Populetum nigro - albae).

Potencijalna šumska vegetacija: Rejon pripada sjeverozapadnom graničnom području areala klimatogene fitocenoze sladuna i cera; dominirajuća je azonalna fitocenoza lužnjaka i običnog graba, a sporadično ova staništa pripadaju kao recentni fluvisoli šumama vrba i šumama crne i bijele topole.

\subsubsection{Majevički rejon}

Položaj: Sjeverni i sjeveroistočni obronci Majevice do pobrežja nad dolinom Drine kod Zvornika, između 200 i $700 \mathrm{~m}$ nadmorske visine, pripadaju brdskom pojasu (submontano-montanom).

Geomorfologija i geološka građa: U geomorfološkom pogledu to su aluvijalne ravni i diluvijalne terase (polja), te brežuljkasto brdski tereni izgrađeni od tercijarnih sedimenata (uglavnom eocenski fliš).

Zemljišta: Najzastupljeniji je distrični kambisol, a potom manje dolaze vertisol, pelosol, fluvisol, pseudoglej, eutrični kambisol te kalkokambisol na krečnjaku.

Distrični kambisol je razvijen na eocenskom flišu i ostalim tercijarnim sedimentima i vrlo je varijabilnih svojstava. Međutim, za rasadničku proizvodnju je veći problem izbor odgovarajućeg položaja i veličine, nego li svojstva zemljišta.

Realna šumska vegetacija: U mozaičnom rasporedu zastupljene su: šume kitnjaka i običnog graba (Querco - Carpinetum), šume sladuna i cera (Quercetum confertae - cerris), šume kitnjaka i cera (Quercetum petraeae - cerris) i šume bukve, sa preovlađivanjem acidofilne šume (Luzulo - Fagetum), a vrlo sporodično neutrofilne (Fagetum montanum illyricum).

Potencijalna šumska vegetacija: U zapadnom dijelu rejona preovlađuju klimatogene šume kitnjaka i običnog graba a u istočnom klimatogene šume sladuna i cera, na svom sjeverozapadnom rubu areala. Iznad sladuna i cera, kao visinski pojas zastupljene su šume kitnjaka i cera. Orografski uslovljene, na hladnijim položajima, interpolirane su šume bukve (pretežno Luzulo - Fagetum).

\subsubsection{Srebrenički rejon}

Połožaj: Od doline Drine - njenog izlaska iz klisure do Zvornika, na jugozapad do obronaka Javor planine, obuhvata visinski interval od 150 do $1020 \mathrm{~m}$ nadmorske visine. Pripada brdsko-planinskom pojasu, osim uske zone doline Drine.

Geomorfologija i geološka građa: U geomorfološkom pogledu izdvajaju se manje aluvijalne ravni i terase, te planinski masivi.

Rejon karakteriše masiv eruptivnih stijena sa paleozojskim škriljcima i pješčarima, kao i trijaskim krečnjacima, te pješčarima, glincima i rožnjacima.

$\mathrm{Z}$ e m l j išt a: Najzastupljeniji tip zemljišta je distrični kambisol, a na manjim površinama javljaju se i zemljišne kombinacije tipa mozaika kalkomelanosola, kalkokambisola na krečnjaku i eutričnim kambisolom na silikatnim stijenama.
Ovo su tipična šumska zemljišta. Na krečnjacima su pretežno plitka i suha, dok su na ostalim supstratima srednje duboka i duboka, i znato vlažnija.

Za rasadničku proizvodnju su povoljnija zemljišta na silikatnim supstratima (zbog povoljnijeg mehaničkog sastava).

Realna šumska vegetacija: Preovlađuju šume bukve acidofilnog karaktera (Luzulo - Fagetum), sporadično (Musci - Fagetum), a na krečnjačkim zemljištima rasprostranjene su neutrofilne šume bukve (Fagetum montanum illyricum). Značajan udio imaju razne fitocenoze hrastova, po zastupljenosti: šume kitnjaka i cera (Quercetum petraeae - cerris), šume sladuna i cera (Quercetum confertae - cerris), brdske šume kitnjaka (Quercetum petraeae montanum) i šume kitnjaka i običnog graba (Querco - Carpinetum).

Sasvim sporadično, orografski uslovljene, javljaju se termofilne šume bukve (Ostryo - Fagetum) i šume hrastova i crnog graba (Querco - Ostryetum), odnosno graba (Orno - Ostryetum).

Potencijalna šumska vegetacija: Klimaregionalno ovaj rejon bi karakterisale slijedeće fitocenoze, po zastupljenosti: šume bukve $i$ jele (bez smrče) acidofilnog karaktera (Fago - Abietetum $=$ A. - F. silicicolum) odnosno neutrofilne (Abieti $-\mathrm{Fa}$ getum illyricum), zatim šume bukve (preovlađuju Luzulo - Fagetum, sporadično Musci - Fagetum, a na krečnjačkim zemljištima Fagetum montanum illyricum).

Od hrastovih fitocenoza kao klimatogena je šuma sladuna i cera koja se ovdje nalazi na sjeverozapadnoj granici svoga areala. Na nju se nadovezuje šuma kitnjaka i cera, a iznad ovih šuma kitnjaka. Na plakornim položajima rasprostranjena je šuma kitnjaka i običnog graba. Termofilne hrastove fitocenoze kao i termofilne šume bukve zauzimaju sporodično, najekstremnija staništa.

Uska zona doline Drine pripada azonalnim fitocenozama vrba (Salicetum) i topola (Populetum nigro albae).

\subsection{Gornje drinsko područje}

Položa j: Brdsko-planinski predjeli jugoistočne Bosne od obronaka Jahorine, Ravne planine i Romanijske visoravni na sjeverozapadu, do granice sa SR Srbijom i SR Crnom Gorom, na jugoistoku, odnosno od kanjona Tare i Drine, na jugozapadu do Stolac planine i kanjona Drine, na sjeveroistoku.

Zauzima visinski interval od $350 \mathrm{~m}$ (dolina Drine kod Višegrada) do $2238 \mathrm{~m}$ nadmorske visine (vrh V. Ljubišnje).

Klima: Niži dijelovi ovoga područja (oko Višegrada i šire okoline Goražda) su pod uticajem umjereno kontinentalne klime sa tendencijom opadanja padavina i povećanjem temperature u periodu od juna do početka septembra. Još veći uticaj mediteranske klime osjeća se u području Foče. Viši položaji (ogranci Jahorine, Ljubišnje, Stakorine) su sa izmijenom umjereno kontinentalnom klimom sa obilježjima planinske klime. Odnos padavina i potencijalne evapotranspiracije $u$ vegetacionom periodu je veoma nepovoljan (oko 0,83 ), što, uz relativno malu rezervu biljkama pristupačne vode u zemljištu čini ovo područje veoma kserotermnim (vidi tabelu 2 i grafikone 1 i 2). Trajanje vegetacionog perioda je od 140-200 dana.

Geomorfologija i geološka građa: U ovom geomorfološki relativno homogenom području (padine gornjeg toka rijeke Drine) zastupljeni su grauvakni pješčari i škriljci, pretežno argilofiliti, krečnjaci i serpentiniti. 
Z em 1 jišta: Zemljišta su najvećim dijelom u odjelu automorfnih $\mathrm{i}$ to klase kambičnih zemljišta.

Realna šumska veget acija: U nižim predjelima preovlađuju hrastove fitocenoze - šume sladuna i cera (Quercetum confertae - cerris), iznad njih su šume kitnjaka i cera (Quercetum petraeae - cerris), odnosno šume kitnjaka (Quercetum petraeae montanum), na toplijim položajima, dok su na hladnijim položajima šume bukve. Ovdje su vrlo rijetko zaostale enklave šume bukve i jele sa smrčom (Piceo - Abieti - Fagetum).

$\mathrm{Za}$ više predjele karakteristične su: fitocenoze bukve (Fagetum montanum illyricum et Luzulo - Fagetum), šume bukve i jele sa smrčom (Piceo - Abieti Fagetum), šume jele i smrče (Abieti - Piceetum), te šume subalpinske smrče (Piceetum subalpinum) i klekovina bora (Pinetum mugi) na masivu Ljubišnje i Radovine.

U kanjonima rijeka i na litičastim padinama zastupljene su termofilne fitocenoze: šume crnog bora (Pinetum nigrae catcicolum), šume crnog graba (Orno Ostryetum) i šume bukve i crnog graba (Ostryo - Fagetum).

Za višegradski rejon ovog područja karakteristično je da pripada ofiolitskoj zoni Dinarida koju karakterišu veoma heterogene orograsko - edafske i vegetacijske prilike. Mozaično se smjenjuju različite hrastove fitocenoze, fitocenoze crnog bora (Pinetum nigrae serpentinicum et Pinetum nigrae baziferens), te fitocenoze bukve, odnosno bukve i jele (sa smrčom).

Potencijalna šumska vegetacija: Niži tereni pripadaju klimazonalnoj fitocenozi sladuna i cera, koja ovdje predstavlja sjeverozapadni rub areala ove istočno-balkanske fitocenoze iznad koje se javljaju karakteristični pojasevi šuma kitnjaka i cera, odnosno kitnjaka. Sa ovim se smjenjuju šume bukve, na hladnijim položajima. Viši predjeli pripadaju pojasu klimaregionalne zajednice bukve i jele sa smrčom.

Subalpinski predjeli Ljubišnje i Radovine pripadaju klimaregeonalnim pojasevima subalpinske smrče i klekovine bora. Fitocenoze subalpinske smrče, kao posebni pojas, karakteristične su inače za planine is točnobalkanskog područja.

U klisurama i litičastim padinama zastupljene su reliktne fitocenoze crnog bora, crnog graba, termofilne šume bukve. Recentni fluvisoli predstavljaju staništa šuma vrba i topola.

Za Višegradski region ofiolitske zone, osim nekih već navedenih fitocenoza, znatne površine predstavljaju staništa šume crnog bora, koja je orografski uslovljena kao trajni stadij vegetacije.

\subsubsection{Višegradski rejon}

Položa j: Zauzima dio istočne Bosne, od rijeka Lima i Drine do granice sa SR Srbijom. Orografski pripada brdsko-plininskom pojasu, od 350 do $1389 \mathrm{~m}$ nadmorske visine (vrh Velike Varde).

Geomorfologija i geološka građa: U geomorfološkom pogledu ovo je vrlo razveden rejon, uglavnom izgrađen od serpentinita, kiselih silikatnih stijena, te krečnjaka $\mathrm{i}$ dolomita. $\mathrm{U}$ dolinama rijeka obrazovane su aluvijalne ravni.

$\mathrm{Z}$ emljišta: Najzastupljeniji tipovi zemljišta su eutrični kombisoli na serpentinitu i distrični kambisoli na kiselim silikatnim stijenama, te zemljišne kombinacije mozaičnog tipa kalkomelanosola, kalkokambisola i luvisola na krečnjaku, zatim rendzine na dolomitu, eutričnog kambisola i fluvisola.
Ovo je izrazito šumski rejon, koji posebno karakterišu zemljišta razvijena na serpentinitu (gdje postoji neuravnotežen odnos između $\mathrm{Ca}: \mathrm{Mg}$, a zemljišta su plitka i suha).

Realna šumska vegetacija: Dominantne su šume crnog bora na eruptivnim stijenama: peridotitu - serpentinitu, gabru i dijabazu (Erico - Pinetum serpentinicum, Pinetum nigrae baziferens), a na dubljim zemljištima šume sladuna i cera (Quercetum confertae - cerris), a iznad ovih šume cera i kitnjaka (Quercetum petraeae - cerris). Od ostalih, rasprostranjene su šume bukve (Luzulo - Fagetum et Fagetum montanum illyricum), šume bukve i jele (sa smrčom) $($ Fago - Abietetum $=A$. $-F$. silicicolum et Abieti Fagetum illyricum) na različitim geološkim podlogama (amfiboliti, amfibolitski škriljci, pješčari - glinci, krečnjaci i dr.). Sporadično, na ekstremno toplim položajima u klisurama rijeka, rasprostranjene su šume bijelog graba (Carpinetum orientalis illyricum).

Potencijalna šumska vegetacija: Śume crnog bora kao trajni stadij vegetacije, šume sladuna i cera kao klimatogene a iznad su šume kitnjaka i cera i šume kitnjaka. Dijelovi ovog rejona pripadaju i klimatogenim šumama bukve i jele (sa smrčom).

\subsubsection{Rogatički rejon}

Položaj: Uže područje donjeg sliva Prače od 320 do $1100 \mathrm{~m}$ nadmorske visine. Po orografskim karakteristikama pripada brdsko - planinskom pojasu.

Geomorfologija i geološka građa: U geomorfološkom pogledu izdvajaju se vrtačaste krečnjačke cjeline sa kanjonima, te blaže izražene forme tercijarnih tvorevina (u okolini Mesića i Rogatice).

$\mathrm{Z}$ e m $1 \mathrm{j}$ iš ta: Od zemljišta najzastupljenija je zemljišna kombinacija tipa mozaika kalkomelanosola sa kalkokambisolom (manje kao tročlana sa luvisolom) na krečnjaku, zatim distrični kambisol, kompleks luvisola i pseudogleja na tercijarnim sedimentima i fluvisoli.

Zemljišta na krečnjacima su plitka i suha, teškog mehaničkog sastava sa dosta izraženom kamenitosti površine i skeletnosti profila.

Realna šumska vegetacija: Mozaično su zastupljene šume cera i kitnjaka (Quercetum petraeae - cerris), šume bukve (Fagetum montanum illyricum et Luzulo - Fagetum); u termofilnijim uslovima, šume cera (Orno - Quercetum cerris) a na ušču Prače šume sladuna i cera (Quercetum confertae - cerris). Sporadično se nalaze ostaci šuma kitnjaka i običnog graba (Querco - Carpinetum), te šume hrastova i crnog graba (Querco - Ostryetum).

Potencijaln šumska vegetacija: Najdominantnije bi bile šume kitnjaka i cera, odnosno šume cera, zatim šume bukve i jele sa smrčom. Brežuljkasti tereni oko Rogatice pripadaju šumi kitnjaka i običnog graba a sama aluvijalna ravan šumi lužnjaka i obiěnog graba (Carpino betuli - Quercetum roboris). Ekstremne krečnjačke padine predstavljaju staništa šuma hrastova i crnog graba (Querco - Ostryetum carpinifoliae).

\subsubsection{Goraždansko-fočanski region}

Polożaj: dijelovi slivnog područja toka Drine uzvodno od Foče do ispod Goražda, kao i izvorišno područje Prače, u visinskom intervalu od $340 \mathrm{~m}$ (dolina Drine) do $1750 \mathrm{~m}$ nadmorske visine (jugoistočni dijelovi Jahorine). Pretežno pripada brdsko-planinskom pojasu, znatno manje subalpinskom pojasu, a samo dolina Drine nizinskom (kolinskom).

Geomorfologija i geološka građa: Ovaj rejon, u geomorfološkom pogledu, karakteriše pla- 


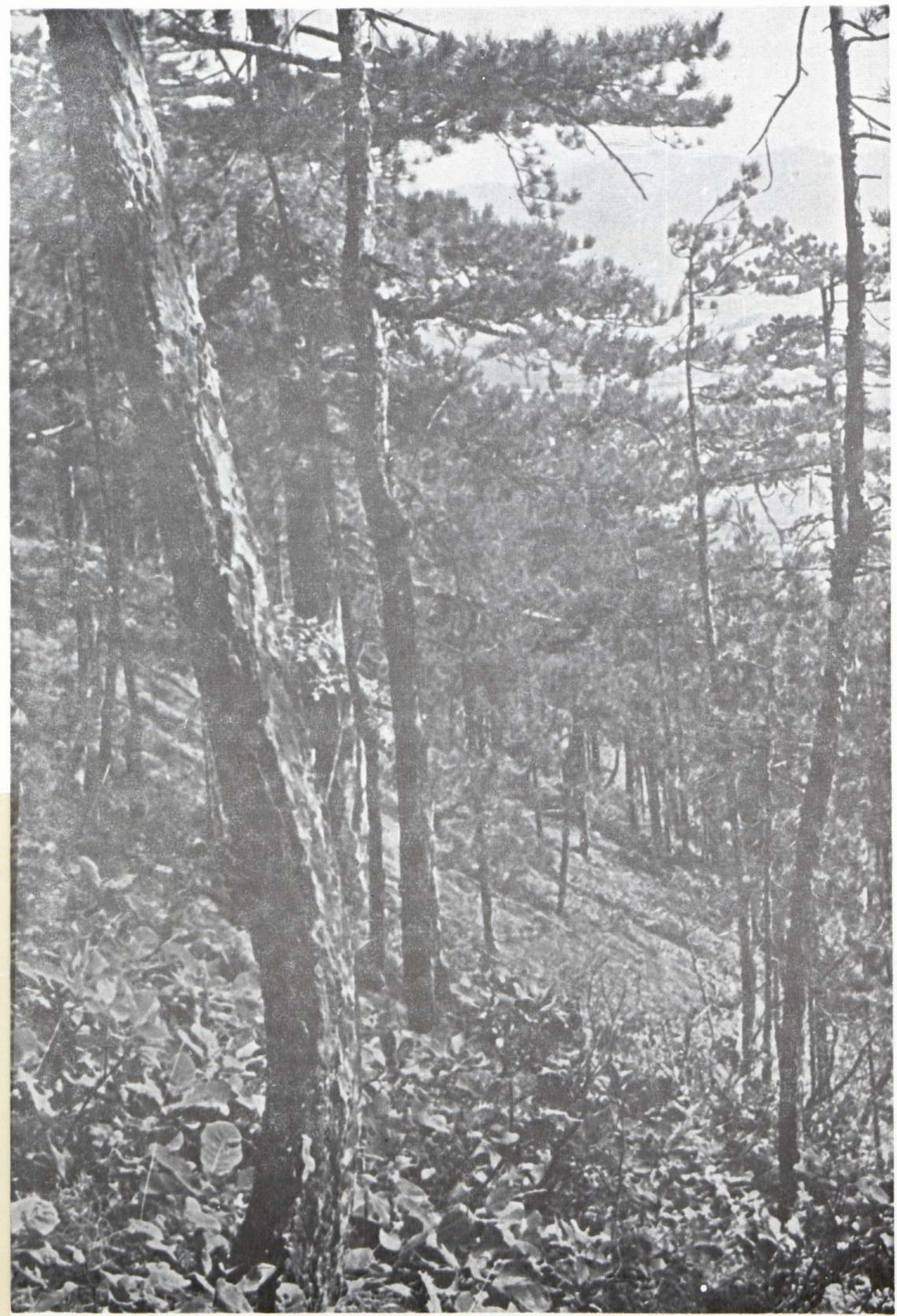

Slika 2 - Sume crnog bora na rankeru i eutričnom smeđem zemljištu na peridotitu u višegradskom području (foto 
ninski reljef inspresjecan vodotocima, a uglavnom je izgrađen iz paleozojskih pješčara i škriljaca. U dolinama rijeka nalazimo recentne aluvijalne ravni i stare diluvijalne terase.

$\mathrm{Z}$ e m lj išt a: Najzastupljeniji je distrični kambisol, a u dolinama rijeka se još nalaze i fluvisoli. oblasti.

Ovo je najhomogeniji rejon unutar područja, pa i

Zemljišta su relativno povoljnih svojstava, međutim za rasadničku proizvodnju problem predstavljaju izbor povoljnog položaja i veličine rasadnika.

Realna šumska vegetacija: U najnižem dijelu zastupljena je šuma sladuna i cera (Quercetum confertae - cerris) kao klimatogena, a iznad ove, na toplim položajima, šume kitnjaka i cera (Quercetum petraeae - cerris) i šume kitnjaka (Quercetum montanum); na hladnijim položajima šume bukve (preovlađuje acidofilna fitocenoza Luzulo - Fagetum, zatim neutrofilne šume bukve - Fagetum montanum illyricum, šume bukve i jele sa smrčom (acidofilne, Fago Abietetum i neutrofilne, Abieti - Fagetum illyricum), a u subplaninskom pojasu šume bukve (Aceri - Fagetum subalpinum), u kojima je zastupljen češće i planinski javor (Acer heldreichii).

Potencijalna šumska vegetacija: U najnižem pojasu šume sladuna $i$ cera, iznad njih, na toplijim položajima, šume kitnjaka i cera i šume kitnjaka, te šume bukve, bukve i jele sa smrčom i subalpinske šume bukve. Za recentne fluvisole karakteristične su fitocenoze vrba (Salicetum) i topola (Populetum), a u nekim dijelovima šume crne johe (Alnetum glutinosae), odnosno sive johe (Alnetum incanae).

\subsection{4. Čajničko-meštrovački rejon}

Položa j: Viši predjeli jugoistočne Bosne uz granicu sa SR Crnom Gorom i SR Srbijom, od donjeg toka Lima i kanjona Drine na sjeveroistoku do kanjona Tare $\mathrm{i}$ gornjeg toka Drine, na jugozapadu. Izrazito brdsko-planinski reljef sa najvišom subalpinskom zonom Ljubišnje (V. Ljubišnja $2.238 \mathrm{~m}$ nadmorske visine).

Geomorfologija i geološka građa: Ovaj rejon u geomorfološkom pogledu karakterišu visokoplaninski masivi sa izraženim visoravnima i duboko usječenim kanjonima.

Petrografski je vrlo heterogenog sastava. Uglavnom su zastupljeni trijaski krečnjaci, manje eruptivi i tercijarni sedimenti.

$\mathrm{Z}$ e mlj išt a: Najzastupljenije su zemljišne kombinacije tipa mozaika kalkomelanosola - kalkokambisola i distrični kambisol, a manje rendzina na laporcu i fluvisoli.

Distrični kambisoli u ovim klimatskim uslovima podliježu procesima opodzoljavanja.

Realna šumska vegetacija: Preovlađuju šume bukve i jele sa smrčom (acidofilna fitocenoza $\mathrm{Fa}$ go - Abietetum $=$ A. F . silicicolum i neutrofilna Abieti - Fagetum illyricum) kao klimatogene, te šume jele i smrče acidofilnog i neutrofilnog karaktera (Abieti - Piceetum s. 1.).

Značajne površine zauzimaju šume bukve (acidofilnog karaktera Luzulo - Fagetum i neutrofilnog Fagetum illyricum montanum), odnosno šume kitnjaka i cera (Quercetum petraeae - cerris) koje su orografski uslovljene. Znatno manje su zastupljene šume cera (Orno - Quercetum cerris) i kitnjaka (Quercetum petraeae montanum).

U kanjonima su zastupljene, često mozaično raspoređene, termofilne fitocenoze crnog bora (Pinetum illyricum calcicolum), crnog graba (Orno - Ostryetum) i bukve (Ostryo - Fagetum).
U subalpinskoj zoni Ljubišnje i Radovine zastupljene su šume smrče (Piceetum subalpinum) i klekovine bora (Pinetum mugi). Pojava pojasa subalpinske smrče karakteristična je za mezijsku provinciju istočnobalkanskog područja.

Potencijalna šumska vegetacija: Šume bukve $i$ jele sa smrčom, subalpinske šume smrče, šume klekovine bora. Orografski uslovljene, rasprostranjene su šume kitnjaka i cera, zatim šume cera a u višim položajima šume kitnjaka. Za kanjone vezane su šume crnog bora, šume crnog graba i termofilne šume bukve.

\section{OBLAST UNUTRAŠNJIH DINARIDA}

Položa j: Zauzima unutrašnju oblast Dinarida, od Plješevice na sjeverozapadu do Maglića i Volujaka na jugoistoku. Jugozapadnu granicu ove oblasti čine visokoplaninski grebeni i visoravni koje su ujedno granica uticaja mediteranske klime. Prema sjeveroistoku, oblast se spušta prema Pripanonskoj i Prelaznoj ilirsko - mezijskoj oblasti, završavajući se na obroncima viših masiva Dinarida.

Visinski dijapazon, od najniže rubne zone na sjeveroistoku, $300-500 \mathrm{~m}$ nadmorske visine, do najviših predjela 2000-2386 m nadmorske visine, na graničnom području sa mediteransko-dinarskom oblasti. Prema orografskim prilikama pripada pretežno planinsko-subalpinskom pojasu, a samo na sjeveroistočnom rubu ili nekim depresijama u unutrašnjosti i dolinsko - brdskom pojasu.

K li ma: Geografske i geomorfološke prilike ove oblasti uslovljavaju i njenu klimu (Tabela 3). Citava oblast je pod uticajem djelovanja međusobnog sukobljavanja umjerenokontinentalne i izmijenjene mediteranske klime. Visoki planinski masivi uslovljavaju planinsku klimu. Nedovoljan broj i nepovoljan raspored meteoroloških stanica ograničavaju preciznije definisanje uticaja različitih klimatskih struja i njihovo prostorno razgraničenje.

Geomorfologija i geološka građa: U geomorfološkom smislu ovo je vrlo heterogena oblast koju grade tri krečnjačko-dolomitna planinska masiva, dvije bregovite cjeline (ofiolitska zona i Cazinska Krajina), srednje bosansko škriljogorje i sarajevsko-zenička kotlina.

$\mathrm{Z}$ e mljišt a: Kako u geološkom, tako $\mathrm{i}$-u pedološkom pogledu ovo je također vrlo heterogena oblast, čija građa će se detaljnije obraditi unutar pojedinih područja i rejona.

Fitogeografska pripadnost: Oblast pripada ilirskoj provinciji koja se karakteriše svojstvenim vegetacijskim jedinicama i flornim elementima. Od klimazonalne fitocenoze kitnjaka i graba, preko izraženog visinskog zoniranja šuma bukve, bukve i jele (sa smrčom), subalpinske bukve do klekovine bora.

Cjelovitost areala šuma bukve $i$ jele sa smrčom prekinuta je prodorima mediteranskih klimatskih uticaja preko Ivan sedla i dolinom Neretvice u slivno područje Lepenice odnosno prodorima panonskih klimatskih uticaja dolinom Bosne.

Kao specifičnost vegetacije ove oblasti izdvajaju se intrazonalne fitocenoze smrče u planinskim depresijama uslovljene temperaturnim inverzijama, ili u subalpinskom pojasu na najsjenovitijim padinama.

Za neke dijelove ove oblasti - Vranica, Zvijezda, Nišićka visoravan, Ozren, Romanija, Ravna planina Jahorina, karakteristična je pojava fitocenoza i flornih elemenata borealnog karaktera. Od fitocenoza: Lycopodio - Piceetum montanum, Sphagno - Piceetum 

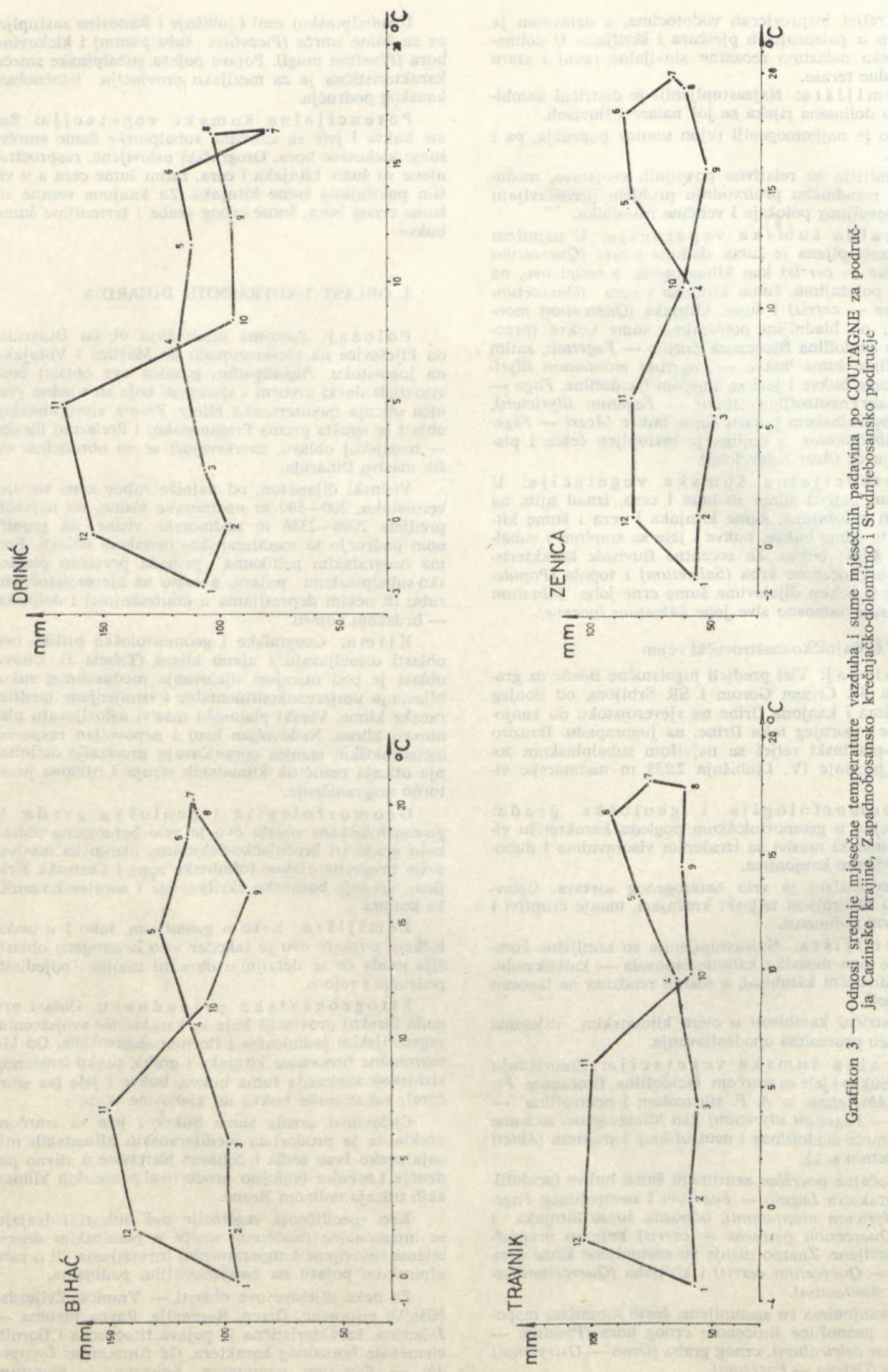


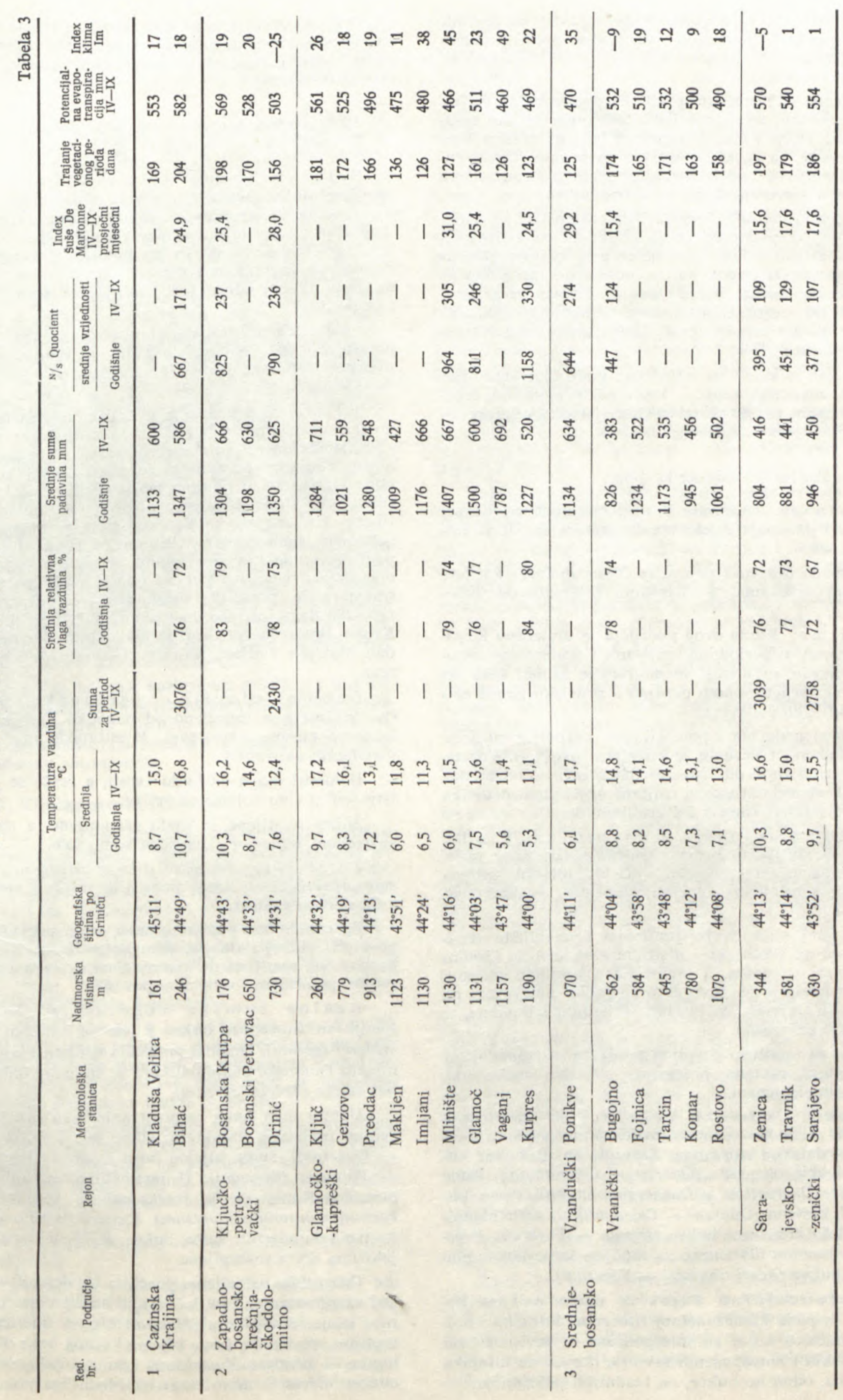


montanum, Pino - Betuletum pubescentis; od flornih elemenata: Listera cordata, Lycopodium sp. div., Cetraria islandica, Sphagnum sp. div., Betula pubescens, Drosera rotundifolia i dr.

Takođe je za oblast specifična pojava nekih reliktnih fitocenoza: tercijarne Pančićeve omorike oko srednjeg toka Drine i glacijalne zelene johe na masivu Vranice planine, sa pojavom alpskih elemenata Rhododendron hirsutum, Vaccinium uliginosum i dr., te šuma kestena u sjeverozapadnom dijelu oblasti.

Posebno obilježje, vegetacijski, ekološki i floristički, u ovoj oblasti predstavlja ofiolitska zona (izdvojeno zavidovičko-tesličko područje), a naročito peridotitsko-serpentinski tereni, koji se odlikuju specifičnim fitocenozama borova (sveze Orno - Ericion serpentinicum) i tzv. serpentinofita, npr. Halacsya sendtneri, Euphorbia gregersenii, Asplenitum cuneifolium, Notholaena marantae $\mathrm{i} \mathrm{dr}$.

Oblast se dijeli na slijedeća područja: cazinske krajine, zapadnobosansko krečnjačko-dolomitno, srednjobosansko, zavidovičko-tesličko, istočnobosanske visoravni i jugoistočnobosansko.

\subsection{Područje Cazinske krajine}

Položa j: Obuhvata krajnji sjeverozapad Bosne, od Une i podnožja Plješevice do granice sa SR Hrvatskom.

Pripada brdskom pojasu sa dosta ujednačenim orografskim prilikama, u visinskom intervalu od 200$550 \mathrm{~m}$.

K I i ma: Klima ovog područja je umjereno kontinentalna, ali u periodima maj-juli i septembar-oktobar osjećaju se uticaji mediteranske klime, tako da sumarno $\mathrm{i}$ vegetacionom periodu $\mathrm{u}$ prosjeku padne oko $48 \%$ godišnjih padavina.

Odnos padavina i potencijalne evapotranspiracije $\mathrm{u}$ vegetacionom periodu je povoljan (oko 1,4 ). Vegetacioni period traje od $170-205$ dana, zavisno od meteoroloških elemenata uzetih u obračun za stanice Velika Kladuša i Bihać (tabela 3 i grafikoni 3 i 4).

Geomorfologija i geološka građa: Ovo je brežuljkasto brdsko područje, izraženog relje$\mathrm{fa}$, izgrađenog od krečnjaka i kiselih silikatnih stijena često prekrivenih sa debelim nanosima beskarbonatnog lesa.

Z e mljišt a: Najzastupljenija su zemliišta akrični luvisol na krečnjaku i distrični kambisol na kiselim silikatnim stijenama, a manje su zasturpljeni mozaici kalkomelanosola sa luvisolom ili kalkokambisola na krečnjaku, luvisola na kiselim silikatnim stijenama, te semigleja i fluvisola.

Ovo su relativno povoljna zemljišta za raspadničku proizvodnju premda pokazuju izvjesne nedostatke hranljivih elemenata.

Realna šumska vegetacija: Rasprostranjena je mozaično veoma uslovljena antropogenim $i$ orografsko-edafskim uticajima. Zastupljene su šume: kitnjaka i običnog graba (Querco - Carpinetum), šume kitnjaka (Quercetum petraeae montanum), šume kitnjaka i kestena (Querco - Castanetum), te u hladnijim položajima šume bukve (Luzulo - Fagetum, Fagetum montanum illyricum); na toplijim šume javora gluhača i bukve (Aceri obtusati - Fagetum).

Potencijalna šumska vegetacija: Područje pripada klimazonalnoj fitocenozi kitnjaka i običnog graba u kojoj su interpolirane, u zavisnosti od orografskih i antropogenih faktora, fitocenoze kitnjaka i kestena, odnosno bukve, na hladnijim položajima.
Dolinski predjeli pripadaju šumama lužnjaka i običnog graba (Carpino betuli - Quercetum roboris), odnosno recentni fluvisoli šumama vrba i topola (Salicetum et Populetum).

\subsection{Zapadnobosansko krečnjačko-dolomitno područje}

Položaj: Zauzima velika geografska prostranstva kreěnjačko-dolomitnih površi i planinskih masiva od Une, na sjeverozapadu do uključujući Glamočko-kuprešku visoravan na jugoistoku. Graniči se sa mediteransko-dinarskom oblasti, na jugozapadu dosežući do doline Vrbasa, linijom Voljevac - Jajce, odakle prelazi na desnu obalu, zahvatajući krečnjačke masive Vlašića i cemernice.

Većim dijelom pripada planinskom i subalpinskom pojasu, od $800(900 \mathrm{~m})$ do $1900 \mathrm{~m}$. Manjim dijelom predstavlja brdsko područje, od $300-700(800) \mathrm{m}$ nadmorske visine.

K I i ma: Ovo područje se karakteriše sa nedovoljno jasnim međusobnim prodorima mediteranske i kontinentalne klime. Prema analizi podataka za stanicu Drinić, u zimskom periodu preovladava uticaj kontinentalne klime, dok u ljetnom periodu su jači uticaji mediteranske klime. Relativno položen tok linija na grafikonu 3 ukazuje i na karakteristike planinske klime uslovljene nadmorskom visinom područja. I u ovom području pada $u$ vegetacionom periodu manji dio godišnjih padavina, pa ipak su odnosi padavina i evapotranspiracije povoljni. Vegetacioni period traje od 120-200 dana, zavisno od nadmorske visine (Bosanska Krupa, Bosanski Petrovac, Drinić, Ključ, Gerzovo, Preodac, Makljen, Imljani, Mlinište, Glamoč, Vaganj i Kupres).

Geomorfologija i geološka građa: Ovo područje je izgrađeno od nekoliko krečnjačko-dolomitnih masiva i visoravni. Mjestimično ima tragova glacijalnih aktivnosti.

Dolomiti mogu da budu čvrsti, a češće se javljaju istrošeni $u$ vidu dolomitne pržine.

Silikatne stijene su malo zastupljene, a na njima susrećemo, uglavnom, distrične kambisole.

$\mathrm{Z}$ e m 1 j i št a: Karakteristike zemljišta su plitkoća, suhoća, skeletnost, težak mehanički sastav i visoka površinska kamenitost.

Za rasadničku proizvodnju, $u$ ovom području, hajpovoljnija bi bila dublja, deluvijalno koluvijalna, bezkarbonatna zemljišta na krečnjacima ako zadovoljavaju svojim položajem i veličinom površine.

Realna šumska vegetacija: Najzastupljenije su fitocenoze bukve i jele sa smrčom (Piceo-Abieti-Fagetum). Dijelovi područja izloženi klimatskom uticaju Panonske nizije odlikuju se šumama bukve, jele bez smrče (Abieti-Fagetum).

Unutar ovih šuma rasprostranjene su različite fitocenoze prelaznog karaktera: šume jele i smrče (Abieti - Piceetum), šume bijelog bora i smrče (jele) (Piceo - Pinetum illyricum). U mrazištima zastupljene su mrazišne šume smrče intrazonalnog karaktera ( $P i$ ceetum montanum inversum). Karakteristično je i prisustvo sekundarnih šuma bukve, koje su u nekim dijelovima dosta zastupljene.

Orografski uslovljene, posebno na dolomitnoj podlozi rasprostranjene su, kao trajni stadij vegetacije, borove šume: crnog bora (Pinetum nigrae dinaricum) na toplijim staništima, šume bijelog i crnog bora (Pinetum nigrae - silvestris dinaricum) i šume bijelog bora ( $P$ i. netum silvestris dinaricum) na hladnijim položajima. 
Za subalpinsku zonu karakteristične su šume subalpinske bukve (Fagetum subalpinum) i klekovine bora (Pinetum mugi) kao klimaregionalne, sa interpolacijama šume smrče (Piceetum subalpinum), introzonalnog karaktera.

$\mathrm{Za}$ niže dijelove ovog područja karakteristične su šume kitnjaka i običnog graba, (Querco - Carpinetum), zatim šume bukve (pretežno, Fagetum montanum illyricum).

Za kanjone rijeka i litičaste padine karakteristične su razne termofilne fitocenoze, često sa reliktnim obilježjima: Aceri obusati - Fagetum, Querco - Ostryetum (Orno - Ostryetum), Carpinetum orientalis.

Potencijalna šumska vegetacija: Ovo područje pripada različitim klimatogenim fitocenozama, od klimozonalne fitocenoze kitnjaka i običnog graba, u najnižim dijelovima ovog područja, do klimaregionalnih fitocenoza subalpinskog pojasa - šuma subalpinske bukve, odnosno klekovine bora. Međutim, najveće površine pripadaju klimaregionalnim šumama bukve i jele sa smrčom sa kojima, u mikroklimatski specifičnim staništima, alterniraju mrazišne šume smrče.

Značajno je ukazati da, smrča izostaje u dijelovima područja koji su izloženi klimatskim panonskim uticajima (sjeverni dijelovi područja), kao i prodorima mediteranskih klimatskih uticaja (jugoistočni dijelovi područja iznad Glamočkog polja).

Dolomitni supstrati, dobrim dijelom, predstavljaju stanište borovih šuma kao trajnih stadija vegetacije (navedene su kod opisa realne vegetacije), a kanjoni rijeka i litičaste padine predstavljaju staništa raznih termofilnih fitocenoza (navedene su prethodno), koje sindinamski takođe predstavljaju trajne stadije vegetacije, često sa reliktnim obilježjima.

Ravničarski predjeli, povremeno plavljeni i pod uticajem podzemnih voda, predstavljaju staništa šuma luźnjaka i običnog graba (Carpino betuli - Quercetum ro. boris), a najmočvarnija zemljišta pripadaju šumi crne johe (Alnetum glutinosae).

\subsubsection{Ključko-petrovački rejon}

Položa j: Predjeli s lijeve strane Vrbasa, obuhvatajući masive Manjače i Zmijanja, na jugoistoku od Grmeča i kanjona Une, na sjeverozapadu, uključujući masiv Plješivice, te planine Lunjevače i Jadovnika (Vijenca), na jugu. S obzirom na orografske karakteristike predjeli ovog rejona pripadaju većim dijelom brdsko-planinskom a manjem subalpinskom pojasu. Prostire se, $\mathrm{u}$ visinskom intervalu, od 300 do blizu $2000 \mathrm{~m}$ nadmorske visine, dokle dopiru vrhovi najvećih masiva (Osječenica, Klekovača, Lunjevača).

Geomorfologija i geološka građa: Posebna obilježja ovog rejona, u geomorfološkom pogledu, je pojava vrtačastih visoravni sa izdizanjem viših krečnjačkih masiva na rubovima. Ovaj rejon je uglavnom izgrađen od krečnjaka a manje dolomita.

Z e m $\bar{l}$ ji ̌̆ta: Najzastupljenije su zemljišne kombinacije tipa mozaika $\mathrm{i}$ to najčešće kalkomelanosola - kalkokambisola - luvisola na krečnjaku kao i mozaici dvočlanog tipa serije zemljišta na krečnjacima; rendzine na dolomitu, kalkomenalosol, distrični kambisol i fluvisol.

Ovo su izrazito šumski rejoni i zemljišta su plitka, suha i skeletna.

Za rasadničku proizvodnju najpovoljniji bi bili distrični kambisoli i fluvisoli, ali ova se zemljišta najčešce koriste u poljoprivrednoj proizvodnji.

Realna šumska vegetacija: Preovlađuju šume bukve i jele sa smrčom (Piceo-Abieti-Fagetum) (smrča izostaje iz predjela pod panonskim klimatskim uticajem), sa različitim sekundarnim fitocenozama: jele i smrče (Abieti - Piceetum), bijelog bora i smrče (jele) (Piceo - Pinetum illyricum) i šume bukve (Fagetum montanum).

Niže predjele karakteriše zastupljenost šuma kitnjaka i običnog graba (Querco - Carpinetum), orografski uslovljene šume kitnjaka (Quercetum petraeae montanum) i šume bukve (Fagetum montanum).

Karakteristične su fitocenoze cera i kitnjaka (Quercetum petraeae - cerris) i cera (Orno - Quercetum cerris) na padinama dolina vodotoka i na krečnjačkodolomitnim površima (npr. Petrovačko - Bravsko polje), koje su pod izraženijim uticajima mediteranskih klimatskih prodora.

U široj okolini Titovog Drvara (Vijenac - Jadovnik) na dolomitnim padinama zastupljene su borove šume karaktera trajnih stadija, preovlađuju šume crnog bora (Pinetum nigrae dinaricum) a zastupljene su mješovite šume bijelog i crnog bora (Pinetum silvestris nigrae dinaricum).

Za subalpinsku zonu najviših planina ovog rejona karakteristične su šume subalpinske bukve (Fagetum subalpinum), a na Klekovači pojas klekovine bora (Pinetum mugi).

U kanjonu Une, Sane i Vrbasa, rasprostranjene su termofilne fitocenoze: šume gluhača i bukve (Aceri obtusati - Fagetum), crnog graba (Orno - Ostryetum), šume cera (Orno - Quercetum cerris) i šume javora i lipa (Aceri - Tilietum mixtum) od kojih su neke zastupljene i na litičastim padinama okolnih masiva. Na nižim, najtoplijim položajima, sporadično su zastupljene šume bijelog graba (Carpinetum orientalis).

Potencijalna šumska vegetacija: Najviše površine pripadaju šumama bukve i jele, odnosno bukve i jele sa smrčom, kao klimaregionalnim fitocenozama. Subalpinske zone pripadaju šumama subalpinske bukve, odnosno klekovine bora.

Brdski predjeli pripadaju klimazonalnoj fitocenozi kitnjaka i običnog graba.

Osim ovih, niži predjeli pripadaju i različitim fitocenozama orografsko-edafski uslovljenim: na recentnim fluvisolima to su šume vrba i topola, šume lužnjaka i običnog graba (polje kod Lušci Palanke i Podrašničko polje), gdje najmočvarnija zemljišta predstavljaju staništa šuma crne johe (Alnetum glutinosae), kanjoni i litice termofilne fitocenoze, a u višim predjelima šume kitnjaka i cera, odnosno šume cera.

\subsubsection{Skender vakufski rejon}

Položa j: Zauzima područje od Banja Luke na sjeverozapadu do Travnika na jugoistoku; obuhvata krečnjačke masive koji se stepenasto uzdižu od Osmače preko Tisovca, Cemernice, Ranča planine do Vlašića, kao najvišeg masiva u ovom rejonu. Izrazito brdskoplaninski predjeli sa manjim subalpinskim pojasom na planini Vlašiću, u visinskom rasponu od 300 do preko $1900 \mathrm{~m}$ nadmorske visine (vrh Vlašića $1919 \mathrm{~m}$ ).

Geomorfologija i geološka građa: Planinski masivi desne strane toka Vrbasa sa manjim ili većim vrtačastim zaravnima sa dubokim kanjonima rijeke Vrbasa i Unca.

Ovaj je rejon izgrađen uglavnom od krečnjaka, a manje dolomita i silikatnih stijena.

$\mathrm{Z}$ em ljišta: Najzastupljenija zemljišta su kombinacije - mozaici sastavljeni iz kalkomenalosola kalkokambisola - luvisola na krečnjacima, a manje mozaici litosola i kalkomelanosola na krečnjaku, te kompleksa rendzina i kalkokambisola na dolomitu, i distriěnog kambisola. 


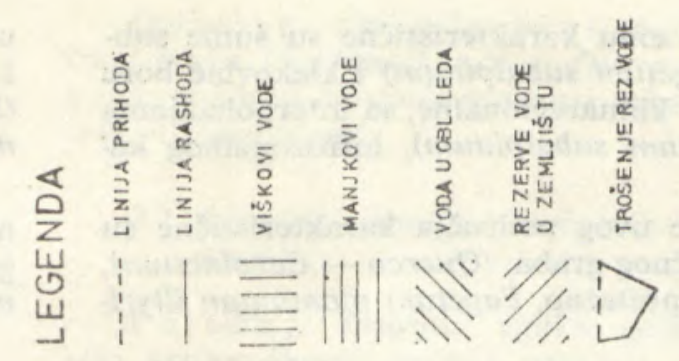

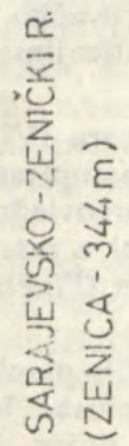
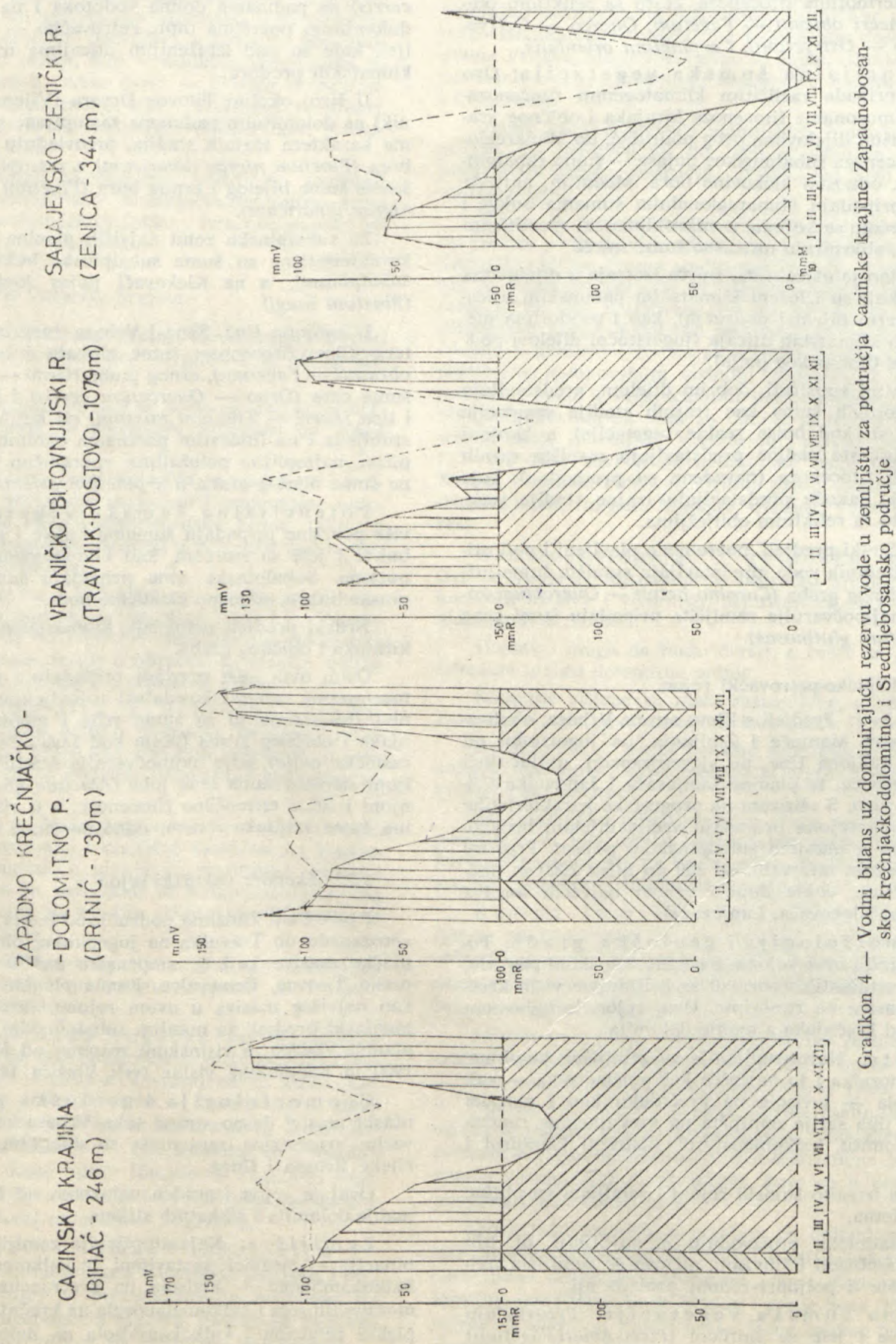
Karakteristike zemljišta ovog rejona su vrlo slične prethodnom.

Realna šumska vegetacija: Najveći dio rejona zauzimaju šume bukve i jele sa smrčom (PiceoAbieti-Fagetum), smrča izostaje u nižim predjelima izloženim uticajima klime Panonskog bazena. Unutar ovih šuma znatne površine zauzimaju sekundarne zajednice jele i smrče (Abieti-Piceetum illyricum) a sasvim neznatno i šume bijelog bora i smrče (Piceo Pinetum illyricum), te sekundarne šume bukve (Fagetum montanum illyricum).

U nižim predjelima rasprostranjene su pretežno šume bukve (Fagetum montanum illyricum), a na toplim položajima šume kitnjaka i običnog graba (Querco - Carpinetum), orografski uslovljene šume kitnjaka (Quercetum petraeae montanum).

U kanjonima rijeka, na stjenovitim strmim padinama, zastupljene su termofilne fitocenoze, često reliktnog karaktera: šume bukve i gluhača (Aceri obtusati - Fagetum), šume crnog graba (Querco - Ostryetum et Orno - Ostryetum), šume lipe i javora (Aceri Tilietum mixtum), a na nižim i najtoplijim položajima šume bijelog graba (Carpinetum orientalis).

Za subalpinsku zonu Vlašića karakteristična je pojava subalpinskih šuma smrče (Piceetum subalpinum) i subalpinskih šuma bukve (Fagetum subalpinum).

Potencijalna šumska vegetacija: Najvećim dijelom rejon pripada klimaregionalnoj fitocenozi bukve i jele sa smrčom, a u nižim predjelima fitocenozi bukve i jele bez smrče.

Subalpinska zona Vlašića pripada klimaregionalnom pojasu bukve, a samo najviši dijelovi oko vrha Vlašića, klekovini bora. Unutar subalpinske zone najhladniji položaji (mrazišta) pripadaju subalpinskoj smrči.

Klisure rijeka, strmi obronci i padine, pripadaju raznim termofilnim fitocenozama, karaktera trajnih stadija vegetacije.

Niži tereni, sa dubljim zemljištima uz širu dolinu Vrbasa, predstavljaju enklave šume kitnjaka i običnog graba, odnosno lužnjaka i običnog graba (Carpino betuli - Quercetum roboris) na riječnoj terasi.

\subsubsection{Glamočko-kupreški rejon}

Položaj: Obuhvata veća prostranstva krečnjačkih i krečnjačko-dolomitnih površi zapadne Bosne sa kraškim poljima, koja su razdvojena planinskim vijencima. Izrazito planinsko područje sa subalpinskim pojasom na najvišim masivima. Pretežno je iznad $1000 \mathrm{~m}$ nadimorske visine sa najvišim kotama oko $1900 \mathrm{~m}$ nadmorske visine.

Proteže se od ruba Bravskog polja, na sjeverozapadu do Vukovskog polja, na jugoistoku.

Geomorfologija i geološka građa: Geomorfološki ovaj rejon predstavljen je visoravnima i kraškim poljima krečnjačko-dolomitnih masiva. Mjestimično su prisutni tragovi glacijacije, koji daju specifične podloge za obrazovanje zemljišta.

$\mathrm{Z}$ e m l j išt a: Zemljišne kombinacije, tipa mozaika između kalkomelanosola - kalkokambisola - luvisola na krečnjacima, su najčešći predstavnici, a manje se javlja rendzina na morenskim materijalima i dolomitima; distrični kambisol, semiglej i fluvisoli.

Zemljišta su vrlo plitka i jako skeletna, sa visokom površinskom stjenovitošću što, uz nepovoljne klimatske faktore, potencira njihovu suhoću.

Realna šumska vegetacija: Najšire rasprostranjenje imaju šume bukve $i$ jele sa smrčom (Piceo-Abieti-Fagetum), unutar kojih su interpolirane veće ili manje površine mrazišnih šuma smrče (Pice- etum montanum inversum), šuma jele i smrče (Abieti - Piceetum illyricum) i šuma bijelog bora i smrče (jele) (Piceo-Pinetum illyricum). Manje površine zauzimaju sekundarne šume bukve (Fagetum montanum). Samo u krajnjem jugozapadnom dijelu iznad Glamočkog polja pojavljuju se šume bukve i jele bez smrče koja izostaje zbog prodora mediteranskih klimatskih uticaja.

U subalpinskoj zoni zastupljene su šume subalpinske bukve (Fagetum subalpinum), sa manjim površinama šuma subalpinske smrče (Piceetum subalpinum), na hladnijim položajima.

Najviše predjele, ovog pojasa, zauzima klekovina bora (Pinetum mugi). Na jugozapadnim padinama i na južnom obodu Glamočkog polja zastupljene su termofilne fitocenoze hrastova i crnog graba (Querco Ostryetum), bijelog graba (Carpinetum orientalis), bukve i javora gluhača (Aceri obtusati - Fagetum), mjestimično, i šume crnog bora (Pinetum nigrae dinaricum).

Potencijalna šumska vegetacija: Najvećim dijelom rejon pripada klimaregionalnoj fitocenozi bukve i jele sa smrčom, unutar kojih depresije pripadaju intrazonalnim šumama mrazišne smrče (naročito velike površine Vukovskog i Kupreško-riličkog polja). Krajnji jugozapadni dio iznad Glamočkog polja pripada šumi bukve $i$ jele bez smrče.

Subalpinski pojas pripada klimaregionalnoj subalpinskoj bukvi, odnosno klekovini bora, a najhladniji položaji intrazonalnoj šumi subalpinske smrče.

Toplije padine oko Glamočkog polja zauzimale su termofilne fitocenoze bukve i javora gluhača, odnosno kitnjaka i crnog graba.

Najniži dijelovi Glamočkog polja (alohtona zemljišta) pripadala su staništima lužnjaka i običnog graba (Carpino betuli - Quercetum roboris), a zamočvarena zemljišta šumi crne johe (Alnetum glutinosae).

\subsubsection{Koprivnički rejon}

Položaj: Zahvata pretežno dolomitne terene u užoj ili široj zoni s lijeve strane Vrbasa, jugozapadno od Mrkonjić Grada, preko Šedinca i Koprivnice, do sliva Duboke jugozapadno od Bugojna. Pretežno pripada planinskoj oblasti, od 500 do preko $1700 \mathrm{~m}$ (vrhovi Plazenice $1704,1724,1760 \mathrm{~m}$ n. v.).

Geomorfologija i geološ ka građa: Vrlo izražen reljef, strme padine, uski grebeni, uske doline.

Rejon je uglavnom izgrađen od dolomita, koji su disjunktno raspoređeni.

Zemljišta: Najzastupljeniji tip zemljišta je rendzina na dolomitu; zatim, kompleksi rendzina i kalkomelanosola na dolomitu, kalkomenalosola i kalkokambisola na krečnjaku, te pseudogleja i fluvisola.

Ovo su nešto dublja zemljišta od predstavnika serije zemljišta na krečnjacima odgovarajuće razvojne stadije, ali su lakšeg mehaničkog sastava pa zadržavaju biljkama manje pristupačne vode.

Zbog toga, kao i zbog strmih padina, ovo su kserotermnija staništa od onih na krečnjacima.

Realna šumska vegetacija: Preovlađuju šume bukve i jele sa smrčom (Piceo-Abieti-Fagetum), unutar kojih su zastupljene borove šume na dolomitnim rendzinama, kao trajni stadiji vegetacije - sume crnog bora (Pinetum nigrae dinaricum), na toplijim položajima, šume bijelog i crnog bora (Pinetum nigrae - silvestris dinaricum) i šume bijelog bora (Pinetum silvestris dinaricum). Mjestimično one alterniraju sa šumama bukve i javora gluhača (Aceri obtusati $-\mathrm{Fa}$ getum). 
Osim ovih, unutar šuma bukve i jele, zastupljene su i sekundarne šume jele i smrče (Abieti - Piceetum illyricum) i bijelog bora i smrče (jele) (Piceo-Pinetum illyricum).

Sekundarne šume bukve (Fagetum montanum), u većim kompleksima, vezane su za masive planine Lisine.

U subalpinskom pojasu Plazenice rasprostranjene su šume bukve (Fagetum subalpinum), te regresivni stadiji zajednica Sorbetum chamaemespilus i Cytisanthetum radiatae.

$\mathrm{Na}$ padinama doline Plive zastupljene su fragmentarno termofilne hrastove šume (Querco-Ostryetum carpinifoliae), šume kitnjaka (Quercetum petraeae montanum) a u podnožjima, kitnjaka i običnog graba (Querco-Carpinetum).

Potencijalna šumska vegetacija: Karakteristično je za ovaj rejon da, najvećim dijelom, pripada klimatogenoj šumi bukve i jele sa smrčom, unutar koje su interpolirane termofilne fitocenoze: borove i bukove šume. Najniži predjeli pripadaju' hrastovom pojasu (pobrežje Bugojanske'kotline, odnosno doline rijeke Plive).

Subalpinska zona Plazenice pripada subalpinskoj šumi bukve.

\subsection{Srednjebosansko područje}

Položaj: Obuhvata teritoriju, od gornjeg toka Bosne na jugozapad, do grebena Ivan Sedla, Bitovnje, Vranice, niz dolinu Vrbasa do Jajca. Sjeveroistočno od doline Bosne dopire do linije Nahorevo-sjeverno od Breze, izvorišnih predjela Žuče i Ribnice, pa na Begov Han pružajući se preko Bosne na sjeverozapad do Banje Luke.

Područje je izrazito brdsko-planinskog karaktera, sa prostranijom subalpinskom zonom na masivima Vranice i Bitovnje, i užom u širom dolinskom zonom uz Bosnu, Lepenicu, Fojnicu i Vrbas.

Visinski se prostire od 300 do preko $2200 \mathrm{~m} \mathrm{n}$. v. (vrhovi Vranice).

K lima: Područje je pod dominantnim uticajem planinske klime. Međutim, od jula do septembra $i$ od decembra do juna, osjeća se djelovanje kontinentalne klime (Zenica). U ostalom dijelu godine jači su uticaji mediteranske klime. U vegetacionom periodu padne oko $48 \%$ godišnjih padavina, ali je odnos padavina, prema potencijalnoj evapotranspiraciji ipak donekle nepovoljan (oko 0,92$)$.

Vegetacioni period (bar $u$ nižem dijelu područja) traje od 180 do 200 dana (tabela 3 i grafikoni 3 i 4).

Geomorfologija i geolosk a građa: Geomorfološki se razlikuju tri cjeline i to: masiv srednjebosanskog škriljogorja (uglavnom izgrađen od kristalastih škriljaca i rioli ta), brežuljkast teren jurskog fliša i Sarajevsko-zenička kotlina (uglavnom izgrađena od tercijarnih sedimenata).

Zemljišta: Zemljišni pokrivač je vrlo heterogen i složen, ali se izdvajaju dosta homogene površine izdvojene u posebne rejone.

Po svojim svojstvima, u ovom području ima više tipova zemljišta, koja bi mogla odgovarati za rasadničku proizvodnju, ali se postavlja problem izbora položaja i veličine povrక̌ine koja nije pod poljoprivrednom proizvodnjom.

Realna šumska vegeta ci ja: Brežuljkaste terene doline Bosne, između Sarajeva i Zenice, odnosno Travnika zauzimaju šume kitnjaka i običnog graba (Querco-Carpinetum), a izvan ovih područja sporadično su zastupljene. Sume kitnjaka alterniraju na toplijim, a bukve, na hladnijim poloěajima.
Ostaci šuma lužnjaka i običnog graba (Carpino betuli-Qurcetum roboris) nalaze se, disperzno, u dolinskim i priterasnim položajima.

Sume bukve, pretežno acidofilnog karaktera (Luzulo-Fagetum), sa fragmentarno zastupljenom šumom rebrače i bukve (Blechno-Fagetum), rasprostranjene su u višim položajima iznad šume kitnjaka i graba ili u alternaciji sa njima.

Sume bukve i jele sa smrčom (Piceo-Abieti-Fagetum) zahvataju velika prostranstva. Međutim, u predjelima na sjeveroistoku područja ove šume nemaju smrču u svom sastavu zbog klimatskih uticaja Panonske nizije, kao i u dijelovima na jugozapadu područja (Bitovnja), zbog prodora mediteranskih klimatskih uticaja.

Za subalpinski pojas vezane su šume subalpinske bukve (Fagetum subalpinum), subalpinske smrče, na hladnijim položajima (Piceetum subalpinum), a iznad ovih klekovina bora (Pinetum mugi).

Specifičnost subalpinskog pojasa kompleksa Vranica su fitocenoze zelene johe (Athyrio - Alnetum viridis) kao glacijalni relikt.

Od sekundarnih fitocenoza zastupljene su šume jele i smrče (Abieti-Piceetum silicicolum), neznatno i sume bijelog bora i smrče (jele) (Piceo-Pinetum silicicolum). Značajne površine zauzimaju i sekundarne šume bukve.

$\mathrm{Na}$ krečnjačko-dolomitnim probojima zastupljene su termofilne fitocenoze bukve i gluhača (Aceri obtusati-Fagetum) i šume hrastova i crnog graba (QuercoOstryetum carpinifoliae), šume bijelog graba (Carpinetum orientalis).

Potencijalna šumska vegetacija: Brežuljkasti tereni pripadaju klimazonalnim šumama kitnjaka i običnog graba (Sarajevsko-zenička kotlina, uz Lašvu do Travnika, dijelovi oko doline Vrbasa i krajnji sjeverozapad područja). Riječne doline i diluvijalne terase pripadaju šumi lužnjaka i običnog graba, a recentni fluvisoli predstavljaju staništa vrba i topola. Orografski uslovljene šume kitnjaka zauzimaju toplije položaje, a hladniji položaji pripadaju staništu bukovih šuma, pretežno acidofilnog karaktera.

Pojasu bukovih šuma pripadaju viši ostrvski položaji unutar brežuljkastih predjela sa hrastovim šumama.

Najveće površine područja pripadaju klimaregionalnim šumama bukve $i$ jele sa smrčom, odnosno šumama bukve i jele.

Subalpinski predjeli pripadaju klimaregionalnim šumama subalpinske bukve i klekovinama bora, s kojima su interpolirane subalpinske šume smrče (masivi Vranice, Sebešića) i zelene johe na Vranici.

Kao trajni stadiji vegetacije zastupljene su termofilne fitocenoze bukve i javora gluhača, medunca i crnog graba, a sasvim sporadično šume bijelog graba.

\subsubsection{Vrandučki rejon}

Položaj: Dužom osi ovaj rejon proteže se od Banje Luke, na sjeverozapadu preko planina Očauš i Vučije planine na dolinu Bosne oko Vranduka - Begov Han do Ponijera, sjeverno od Kaknja, na jugoistoku.

Brdsko-planinski predio, $\mathrm{u}$ visinskom intervalu, od 300 do $1450 \mathrm{~m}$ (sjeveroistočni obronci Vlašića sa Vučijom planinom).

Geomorfologija.igeološka građa: Ovaj rejon je brdsko planinskog karaktera, a uglavnom, izgrađen je od jurskog fliša sa ostrvima krečnjaka i manjim cjelinama laporaca; a u sjevernom dijelu nailazi se na manje partije serpentinita. 
Zemljišta: Najrasprostranjeniji tip zemljišta je distrični kambisol, a podređenu ulogu imaju kombinacije tipa mozaika kalkomelanosola i kalkokambisola na krečnjacima, kao i eutrični kambisol na laporcima i serpentinitu.

Ovo su duboka, skeletna i eroziji podložna zemljišta, te nepovoljna za rasadničku proizvodnju.

Realna šumska vegetacija: Najveći dio zauzimaju šume bukve i jele bez smrče (Abieti-Fagetum), na nižim i izloženim dijelovima panonskim klimatskim uticajima. Sume bukve i jele sa smrčom zauzimaju više predjele Vlašića i Vučije planine. Unutar ovih šuma, javljaju se šume kitnjaka (Quercetum petraeae montanum) koje su orografski uslovljene, neznatnije i termofilne šume bukve (Aceri obtusati - Fagetum).

Međutim, značajnije su rasprostranjene sekundarne šme bukve (Luzulo-Fagetum), a znatno manje šume jele i smrče (Abieti-Piceetum silicicolum).

Potencijalna šumska vegetacija: Navedene fitocenoze kod prikaza realne šumske vegetacije rejona odgovaraju potencijalnim, s time što su sekundarne šume bukve, odnosno jele i smrče na staništima šuma bukve $i$ jele odnosno šuma bukve i jele sa smrčom.

\subsubsection{Vranički rejon}

Položaj: Prostire se od Jajca na sjeverozapadu preko Komara, Vranice i Bitovnje do podnožja krečnjačkih masiva Bjelašnice, na jugoistoku. Dio ovog rejona nalazi se teritorijalno izdvojen obuhvatajući masiv Stožera, istočno od Kupresa. Orografski predstavlja pretežno planinsko područje sa subalpinskim pojasem visokih planina Vranice, Bitovnje i Sebešića. Dolinski (kolinski) pojas, najvećim dijelom, zahvata dolinu Vrbasa.

U visinskom rasponu, proteže se od 400 (500), dolina Vrbasa i sjeveroistočni rubovi rejona do vrhova Vranice, od oko $2200 \mathrm{~m}$ nadmorske visine.

Geomorfologija i geološkagrađa: Ovaj rejon zauzima uglavnom visokoplaninski masiv srednjebosanskog škriljavog gorja, koji je pretežno izgrađen od kristalastih škriljaca, manje eruptiva, krečnjaka i pješčara. Kristalasti škriljci su često rastrošeni glacijalnim i soliflukcijalnim procesima.

Z e ml j išt a: Najzastupljeniji tip zemljišta je distrični kambisol, te zemljišne kombinacije distričnog kambisola i luvisola na kiselim silikatnim stijenama, kao i rankera i distričnog kambisola, te rendzine na dolomitu i mozaik kalkomelanosola i kalkokambisola na krečnjaku.

Po svojim fizičko-hemijskim svojstvima ova zemljišta bi bila pogodna za rasadničku proizvodnju, ali i ono malo pogodnih terena $\mathrm{za}$ istu nalaze se $\mathrm{u}$ poljoprivrednoj proizvodnji.

Realna šumska vegetacija: Najzastupljenije su fitocenoze bukve i jele sa smrčom (preovlađuju acidofilne). Iz jugoistočnog dijela rejona izostaje smrča zbog prodora mediteranskih klimatskih uticaja (Inač, Bitovnja, Mehina Luka). Unutar ovih fitocenoza veće komplekse zauzimaju sekundarne šume bukve (pretežno acidofilnog karaktera (Luzulo - Fagetum), zatim šume jele i smrče (Abieti - Piceetum) i sporadično šume bijelog bora i smrče (jele) (Piceo - Pinetum). Za subalpinski pojas karakteristično je prisustvo subalpinske šume bukve (Fagetum subalpinum), a na masivu Vranice i subalpinske smrče (Piceetum subalpinum). U najvišim predjelima zadržali su se ostaci zajednice klekovine bora (Pinetum mugi). Unutar subalpinskog pojasa, na hladnijim položajima, ljevkastim uvalama, rasprostranjena je šuma zelene johe (Athyrio - Alnetum viridis).

U dolinskim i brdskim predjelima zastupljene su šume kitnjaka i običnog graba, sa orografsko uslovljenim šumama kitnjaka (Quercetum petraeae montanum) koje se u sličnim uslovima prostiru i znatno više.

Manje površine, kserotermnijih staništa, naseljavaju termofilne šume bukve (Aceri obtusati - Fagetum).

Potencijalna šumska vegetacija: Najveće površine pripadaju klimaregionalnoj fitocenozi bukve i jele (sa smrčom), subalpinski pojas, klimaregionalnim šumama subalpinske bukve i klekovine bora, gdje su interpolirane subalpinske šume smrče, odnosno zelene johe.

Dolinsko brdski predjeli pripadaju hrastovim fitocenozama, aluvijalna ravan Vrbasa, šumi lužnjaka i običnog graba (Carpino betuli - Quercetum roboris), blaže padine sa dubljim zemljištima, šumi kitnjaka i običnog graba, a strmije i izloženije, šumi kitnjaka.

\subsubsection{Sarajevsko-zenički rejon}

Položa j: Obuhvata centralne dijelove Bosne, doline rijeke Bosne od Sarajeva do Zenice i dolinom ri. jeke Lašve do Travnika. Predstavlja najvećim dijelom brežuljkasto gorje od 400 do blizu $1300 \mathrm{~m}$ nadmorske visine a samo dolinama rijeke Bosne, Lepenice i Lašve izražen je dolinski pojas.

Geomorfologija i geološka građa: Ovo su tereni brežuljkasto brdskog karaktera ispresjecani sa aluvijalnim ravnima vrlo složenog petrografskog sastava, naročito kompleksi tercijernog fliša.

$\mathrm{Z}$ em 1 j išt a: Najzastupljenija kartografska jedinica je kompleks rendzine, distričnog kambisola i pseudogleja na fliškolikim sedimentima, te niz réndzina i eutričnog kambisola na laporcu; mozaik kalkomenalosola i kalkokambisola i mozaik kalkomenalosola i luvisola na krečnjaku, te kompleks luvisola i pseudogleja na tercijarnim sedimentima, fluvisola u riječnim dolinama.

Pošto je ovo rejon nižih nadmorskih visina, uz riječne tokove, zemljišta se uglavnom koriste u poljoprivrednoj proizvodnji a samo ona najnepovoljnih svojstava su pod šumskom vegetacijom. Unutar ovih površina mogu se naći povoljne površine za rasadnike, ali su zemljišta često nepovoljnih fizičkih svojstava.

Realna šumska vegeta cija: Najzastupljenije su fitocenoze kitnjaka i obiěnog graba (Querco Carpinetum), mozaično rasprostranjene te šume bukve (pretežno Luzulo - Fegetum) i šume kitnjaka (Quercetum petraeae montanum), na toplijim i izloženijim položajima. Mjestimično su zastupljene termofilne fitocenoze bijelog graba (Carpinetum orientalis), na najtoplijim položajima sa plitkim zemljištima, ili šuma hrastova i crnog graba (Querco - Ostryetum carpinifoliae).

$\mathrm{Na}$ ravničarskim terenima nalaze se ostaci lužnjaka i običnog graba (Carpino betuli - Quercetum roboris).

Potencijalna šumska vegetacija: Najvećim dijelom brežuljkasto-dolinski predjeli pripadaju klimazonalnoj zajednici kitnjaka i običnog graba. Unutar ove, ravničarski predjeli predstavljaju staništa šuma lužnjaka i običnog graba, a recentni fluvisoli su staništa vrba i topola (Salicetum et Populetum).

Hladniji i viši položaji predstavljaju staništa šuma bukve, a najtopliji šuma kitnjaka.

Najviši predjeli pripadaju staništu bukve i jele bez smrče (Abieti - Fagetum), koja ovdje izostaje zbog prodora mediteranskih i panonskih uticaja klime. 


\subsection{Zavidovičko-tesličko područje}

Položa j: Obuhvata sliv srednjeg toga rijeke Bosne, posebno Krivaje i Usore, odnosno masiva Konjuha, Ozrena i Borje. Područje se karakteriše i jako heterogenim orografskim prilikama, a nalazi se u brdsko-planinskom pojasu od 250 do $1328 \mathrm{~m}$ nadmorske visine (vrh Konjuha).

Kli ma: Najvećim dijelom godine ovo je područje pod uticajem izmijenjene umjereno kontinentalne klime. Jači uticaj mediteranske klime osjeća se u periodu juni - avgust. Zbog svega toga $\mathrm{u}$ vegetacicnom periodu padne u prosjeku oko $56 \%$ godišnjih padavina, pa je i odnos padavina i potencijalne potrošnje vode, sa klimatskog aspekta, povoljan (tabela 4 i grafikoni 5 i 6).

Vegetacioni period traje 180 do 190 dana (Maoča i Kladanj).

Geomorfologija i geoloska građa: Ovo područje pripada srednjobosanskoj ofiolitskoj zoni, a odlikuje se orografski brdsko-planinskim obilježjima sa dosta izraženim reljefom. Izgrađeno je pretežno od serpentiniziranog peridotita, eruptiva, rožnjaka, a krečnjaci su daleko manje zastupljeni.

$\mathrm{Z}$ em ljišta: Nairasprostranjeniji tipovi zemlijšta su eutrični kambisol na peridotitu i serpentinitu, kao i distrični kambisol na kiselim silikatnim stijenama, manje su zastupljeni eutrični kambisoli na ostalim silikatnim stijenama, pseudoglejevi, mozaik kalkomelansola i kalkokambisola.

Ovo su izrazito šumska zemljišta, plitka i kserotermna. $\mathrm{Za}$ rasadničku proizvodnju nisu pogodna.

Realna šumska vegetacija: Zbog izuzetno heterogenih stanišnih prilika, karakterističnih za ofiolitsku zonu, zastupljene su različite šumske fitocenoze, većinom mozaičkog rasporeda. Najrasprostranjenije su: bazifilne šume borova (Erico-Pinetum nigrae serpentinicum, E. P. nigrae - silvestris serpentinicum), bazifilne śume hrasta kitnjaka (Potentillo albae - Quercetum, Erico - Quercetum petraeae), zatim acidofilne šume kitnjaka (Quercetum petraeae montanum), šume bukve i jele sa smrčom (Abieti - Fagetum serpentinicum), acidofilne šume bukve i jele (Abieti - Fagetum silicicolum).

$\mathrm{Za}$ ovo područje karakteristiěno je pojavljivanje smrče, vezano za peridotitsko-serpentinitska zemljišta u hladnijim i višim položajima, dok na ostalim zemIjištima ofiolitske zone su rasprostranjene šume bukve i jele bez smrče (panonski klimatski uticaji).

Manje površine predstavljaju pretežno fitocenoze bijelog bora i smrče (jele) (Piceo - Pinetum), odnosno jele i smrče (Abieti - Piceetum).

Osim ovih fitocenoza, rasprostranjene su i šume bukve, koje su u višim predjelima i udaljenijim od panonskih uticaja, sekundarnog karaktera.

Ostaci šuma lužnjaka i običnog graba (Carpino betuli - Quercetum roboris) ili kitnjaka i običnog graba (Querco - Carpinetum), na diluvijalnim terasama, su rijetki.

Potencijalna šumska vegetacija: Iz navedenih razloga i potencijalna šumska vegetacija je veoma mozaična. Ipak, veće površine pripadaju šumama bukve i jele bez smrče i šumama bukve $i$ jele sa smrčom, unutar kojih su interpolirane borove i hrastove šume kao trajni stadiji vegetacije.

Samo periferni i najniži predjeli predstavljaju staništa bukve $u$ alternaciji sa hrastovim šumama.

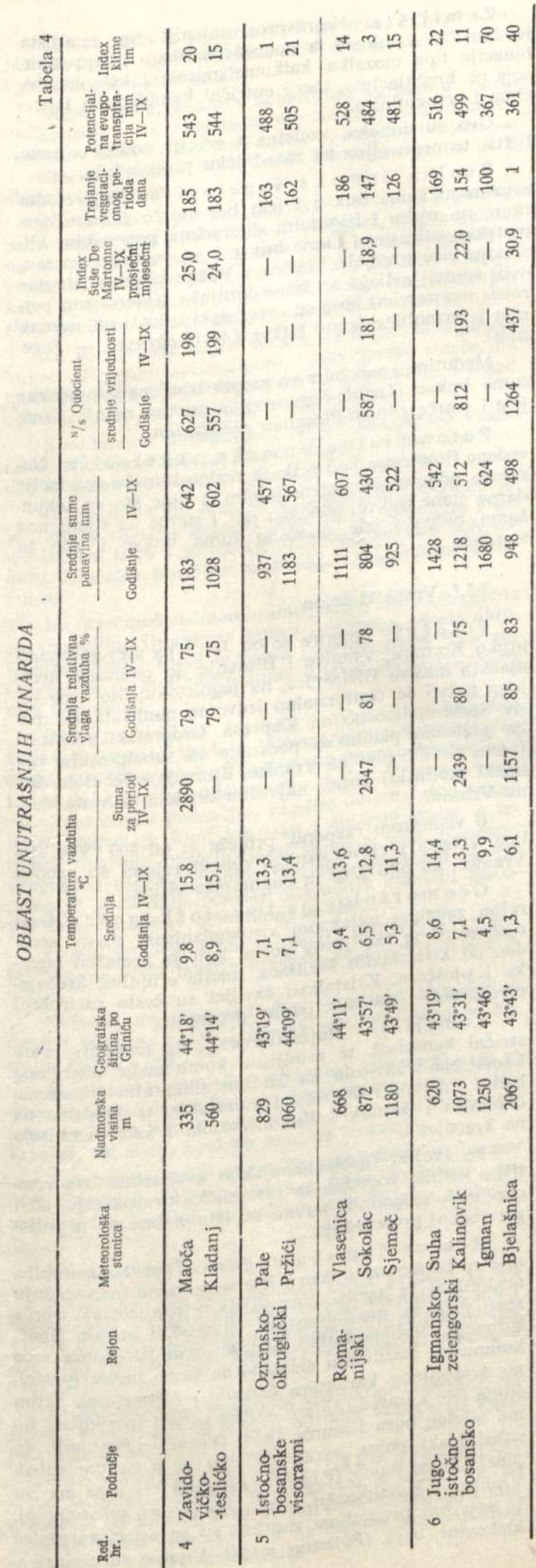



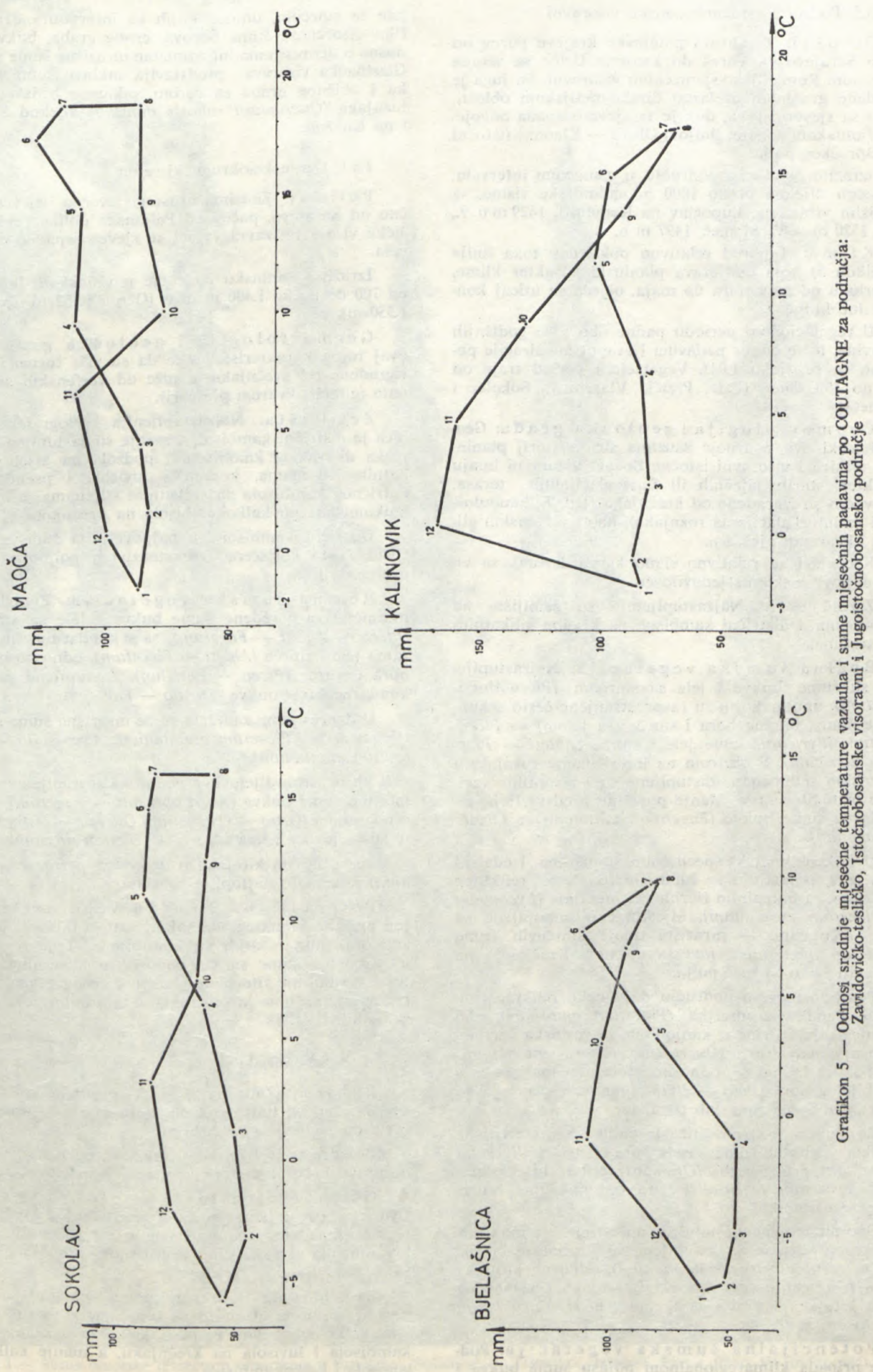
Stefanović V., Beus V., Burlica č., Dizdarević H., Vukorep I.

\subsection{Područje istočnobosanske visoravni}

Položaj: Obuhvata planinske krajeve počev od linije Sarajevo - Vareš do kanjona Drine sa veoma izraženom Romanijsko-sjemečkom visoravni. Sa juga je omeđeno granicom prelazno ilirsko-mezijskom oblasti, kao i sa sjeveroistoka, dok je sa sjeverozapada odvoje na ofiolitskom zonom, linijom Olovo - Kladanj (istočni dio Sprečkog polja).

Izrazito planinsko područje, u visinskom intervalu, najvećim dijelom preko $1000 \mathrm{~m}$ nadmorske visine, sa najvišim vrhovima, Lupoglav na Romaniji, $1629 \mathrm{~m} n$. v., Žep, 1520 m n. v., Sjemeč, $1497 \mathrm{~m}$ n. v.

$\mathrm{K}$ lima: I pored relativno položenog toka linije (grafikon 5) koja obilježava planinski karakter klime, u periodu od novembra do maja, osjeća sé uticaj kontinetalne klime.

$\mathrm{U}$ vegetacionom periodu padne oko $52 \%$ godišnjih padavina, te je odnos padavina i evapotranspiracije povoljan (u prosjeku 1,04). Vegetacioni period traje od 120 do 190 dana (Pale, Pržići, Vlasenica, Sokolac i Sjemeč).

Geomorfologija i geološka građa: Geomorfološki ovo područje zauzima širi teritorij planinskih masiva $i$ visoravnì istočne Bosne. Visoravni imaju karakter starih riječnih ili fluvioglacijalnih terasa. Uglavnom su izgrađene od krečnjaka (jedrih, hanbuloških i sa interkalacijama rožnjaka), kao i verfenskih glinaca i kvarcnih pješčara.

Krečnjaci su relativno slabo karstifikovani, sa visokom površinskom stjenovitošću.

Zemljišta: Najzastupljenija su zemljišta na krečnjacima i distrični kambisoli na kiselim silikatnim supstratima.

Realna šumska vegetacija: Najzastupljenije su šume bukve i jele sa smrčom (Piceo-AbietiFagetum), unutar kojih su rasprostranjene cesto sekundarne šume, bijelog bora i smrče (sa jelom) - PiceoPinetum illyricum, šume jele i smrče (Abieti - Piceetum illyricum). S obzirom na interkalacije rožnjaka i verfenskih sedimenata zastupljene su i acidofilne varijante ovih fitocenoza. Manje površine predstavljaju sekundarne šume bukve (Fagetum montanum et Luzulo - Fagetum).

U mikroklimatski specifičnim staništima, i edafski uslovljene, pojavljuju se šume smrče, cesto reliktnog karaktera, sa borealnim flornim elementima (Lycopodio - Piceetum montanum). Mjestimično zastupljene su i na krečnjacima - mrazišni tipovi smrčevih šuma (Piceetum montanum inversum), npr. Kračipolje na Romaniji i oko Sjemeč polja.

Posebnost ovom području daju neke reliktne fitocenoze Pančićeve omorike (Piceetum omorikae) oko srednjeg dijela Drine u kanjonima, te vesinska varijanta lužnjakovih šuma (Quercetum roboris montanum) kod Sokoca i Knežine, odnosno fitocenoza maljave breze i bijelog bora (Pino - Betuletum pubescentis), kao i zajednice Sphagnum-skih trestišta.

Za kanjone i strme litičaste padine karakteristične su takođe reliktne šume: crnog bora (Pinetum illyricum calcicolum), crnog graba (Orno-Ostryetum), bijelog graba (Carpinetum orientalis) i termofilne šume bukve (Ostryo-Fagetum).

Sporadično, na najtoplijim mjestima, većinom sekundarnog karaktera, zastupljene su fitocenoze kitnja. ka (Quercetum petraeae montanum), odnosno kitnjaka i cera (Quercetum petraeae-cerris), a oko Glasinačkog polja, kitnjaka i graba sa cerom (Querco-Carpinetum cerretosum).

Potencijalna šumska vegetacija: Područje pripada klimaregionalnom pojasu šuma bukve $i$ jele sa smrčom, unutar kojih su interpolirane termofilne fitocenoze šuma borova, crnog graba, bukve, odnosno u depresijama intrazonalne mrazišne šume smrče. Glasinačka visoravan predstavlja enklavu šuma kitnjaka i običnog graba sa cerom, odnosno brdske šume lužnjaka (Quercetum roboris montanum), kod Sokoca i na Knežini.

\subsubsection{Qzrensko-okruglički rejon}

Položa j: Zauzima prostor sjeverno i sjeveroistočno od Sarajeva, počev od Paljanske doline preko Nišićke visoravni, završavajući se sjeverozapadno od Vareša.

Izrazito planinsko područje u visinskom intervalu od 700 do preko $1.400 \mathrm{~m} \mathrm{n}$. v. (Ozren $1.452 \mathrm{~m}$, Zvijezda $1.350 \mathrm{~m})$

Germorfologija i geološka građa: Za ovaj rejon karakteristično je da su više forme reljefa izgrađene od krečnjaka, a niže od verfenskih sedimenata (glinci i kvarcni pješčari).

$\mathrm{Z}$ e m lj i št a: Najzastupljenija kartografska jedinica je distrični kambisol, a manje su zastupljeni kompleks distričnog kambisola i podzola na kiselim silikatnim stijenama, kompleks luvisola i pseudogleja, eutričnog kambisola na silikatnim stijenama te mozaik kalkomelanosola-kalkokambisola na krečnjaku.

Distrični kambisoli su najpovoljnija šumska zemljišta, često korišćena u ekstenzivnoj poljoprivrednoj proizvodnji.

Realna šumska vegetacija: Preovlađuju mozaično raspoređene šume bukve $i$ jele sa smrčom (Piceo - Abieti - Fagetum), sa sekundarnim fitocenozama jele i smrče (Abieti - Piceetum), odnosno bijelog bora i smrče (Piceo - Pinetum). Zastupljene su i sekundarne šume bukve (Luzulo - Fagetum).

U depresijama zadržale su se mrazišne šume smrče (Sphagno - Piceetum montanum, Lycopodio - Piceetum montanum).

U klisurastim dijelovima vodotoka zastupljene su termofilne šume bukve (Aceri obtusati - Fagetum), šume crnog graba (Orno - Ostryetum, Querco - Ostryetum), te šume javora i lipa (Aceri - Tilietum mixtum).

Sume hrasta kitnjaka (Quercetum petraeae monta. num) zauzimaju najtoplije položaje.

Potencijalna šumska vegetacija: Rejon pripada klimaregionalnoj fitocenozi bukve $\mathrm{i}$ jele sa smrčom, unutar kojih su zastupljene, u depresijama, intrazonalne šume smrče, odnosno u klisurama vodotoka, termofilne fitocenoze bukve i crnog graba, šume crnog graba, šume javora i lipa, a na toplim položajima šume kitnjaka.

\subsubsection{Romanijski rejon}

Položa j: Zauzima planinske predjele istočne Bosne, istočno od linije grebena Romanije i Nišićke visoravni do granice sa SR Srbijom.

Prostire se $u$ visinskom intervalu uglavnom od 700 do preko $1.600 \mathrm{~m}$ nadmorske visine (Lupoglav, $1.629 \mathrm{~m}$ ).

Geomorfologija i geološka građa: Ovo je relativno homogen rejon, izgrađen od krečnjaka, te na njima susrećemo uglavnom serije zemljišta na krečnjacima u različitim zemljišnim kombinacijama, što je uslovljeno sa reljefom.

Z emljišta: Najzastupljenije kartografske jedinice ovog rejona su zemljišne kombinacije tipa mozaika i to: kalkokambisola i luvisola, kalkomelanosola, kalkokambisola i luvisola na krečnjaku, a manje kalkomelanosola i kalkokambisola. 


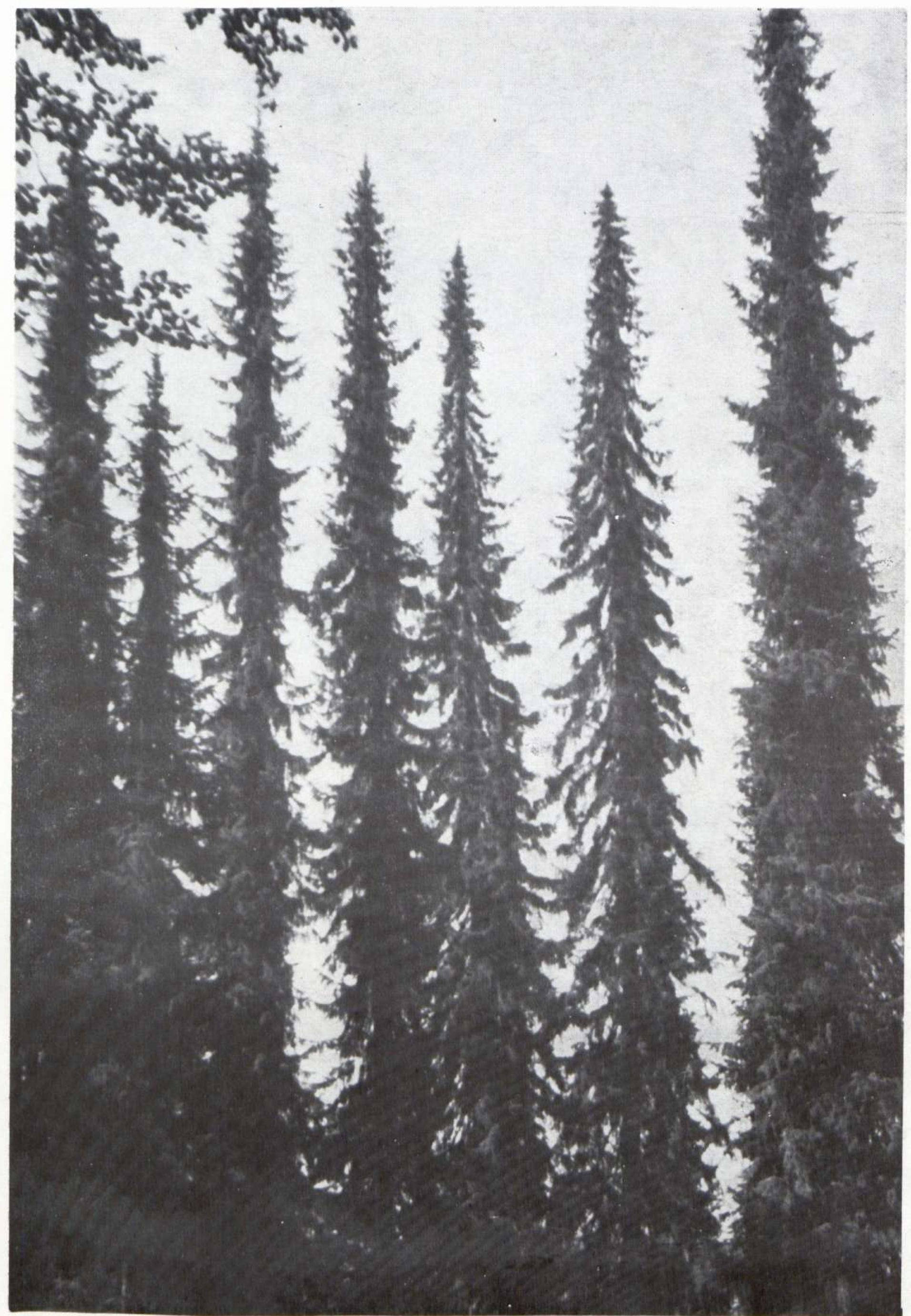

Slika 3 - Suma omorike (Piceetum omorikae) u predjelu Sokoline - Tisovljak, istočna Bosna (foto V. Stefanović) 



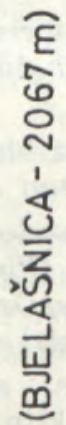
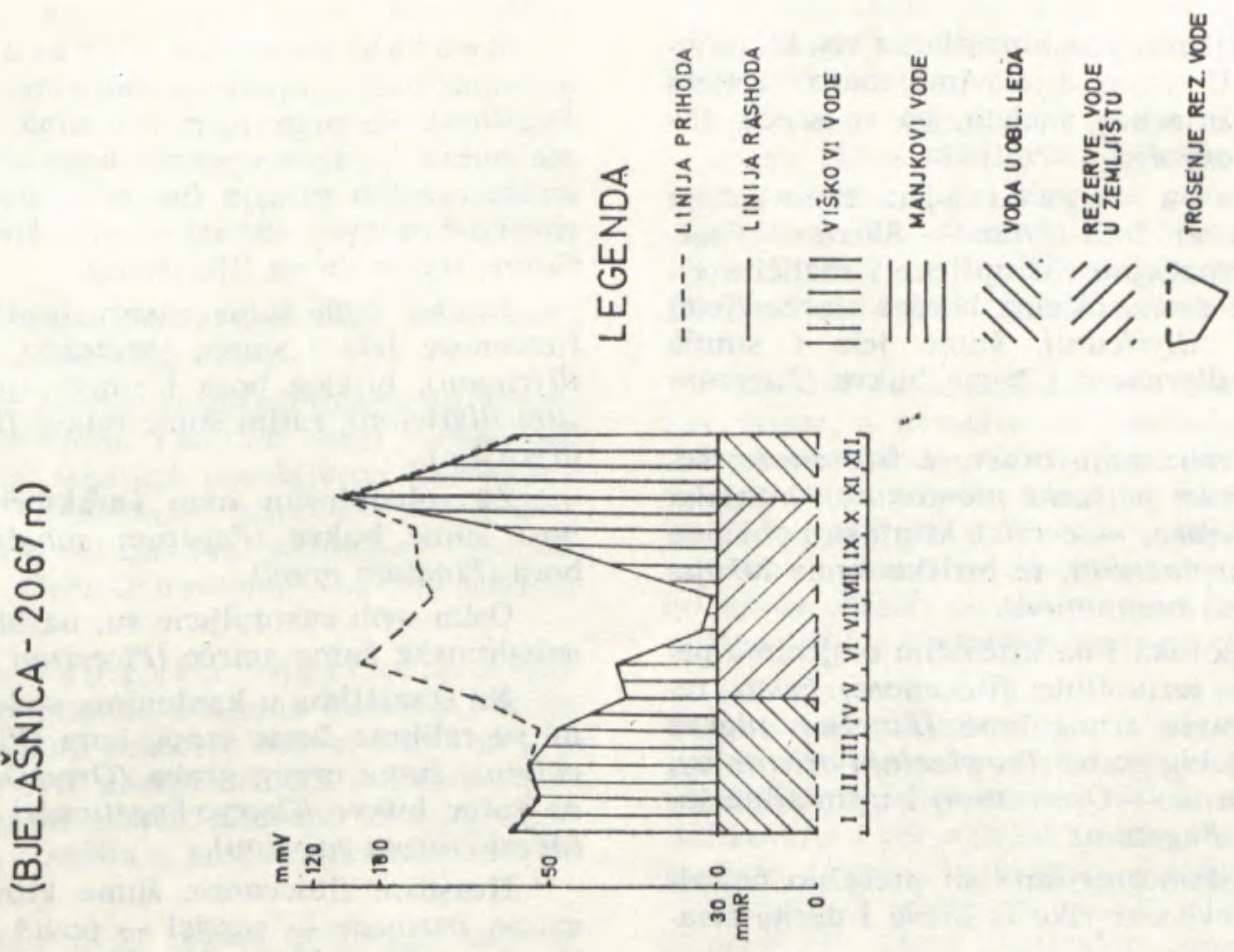

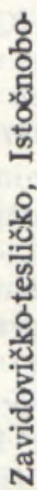

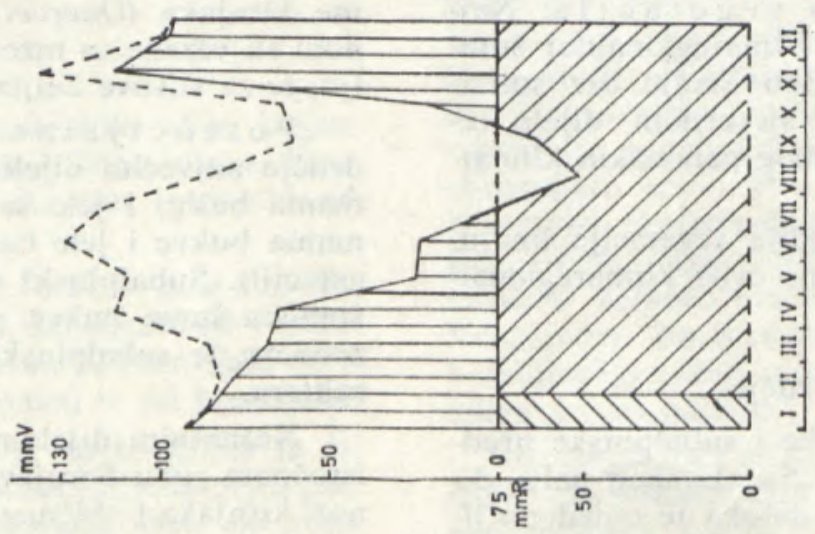

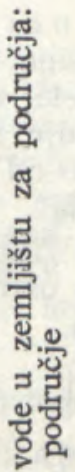

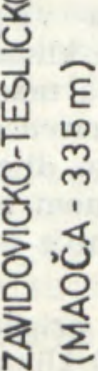
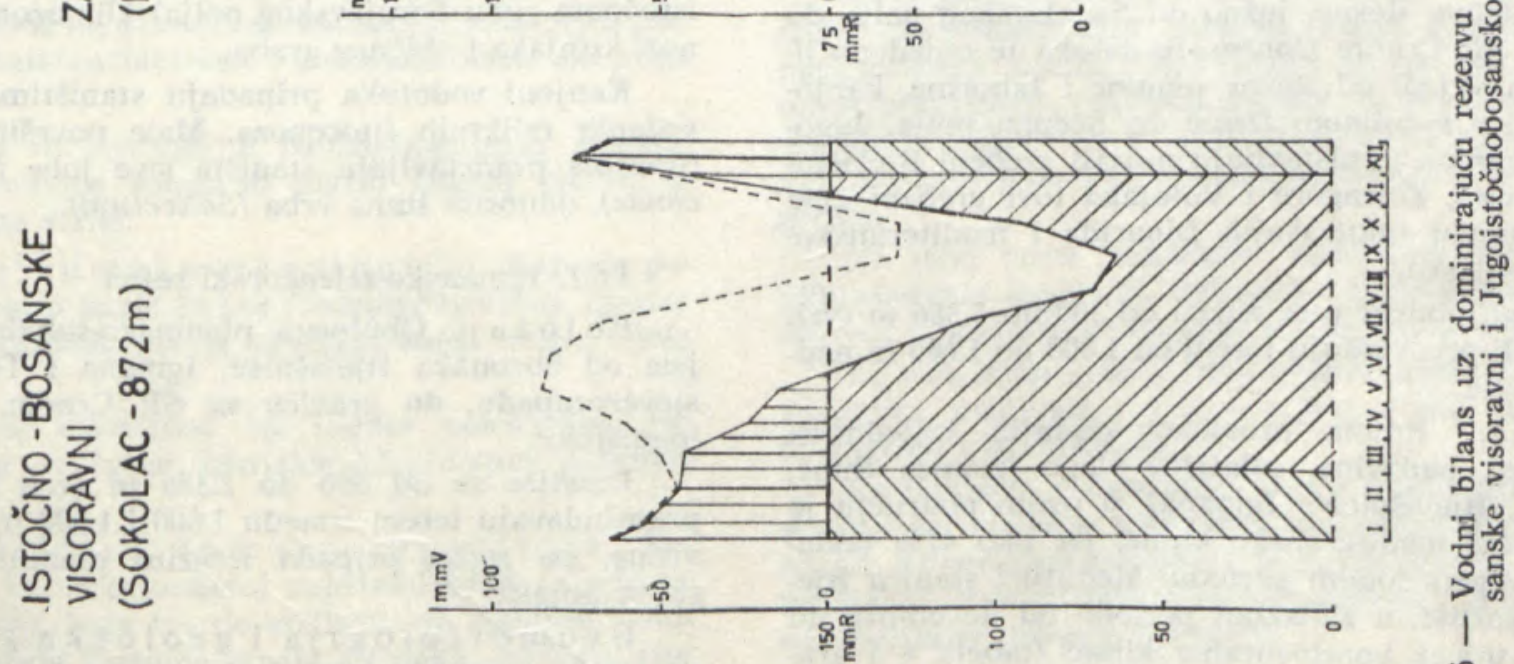

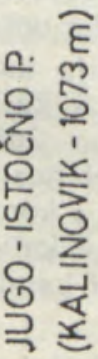
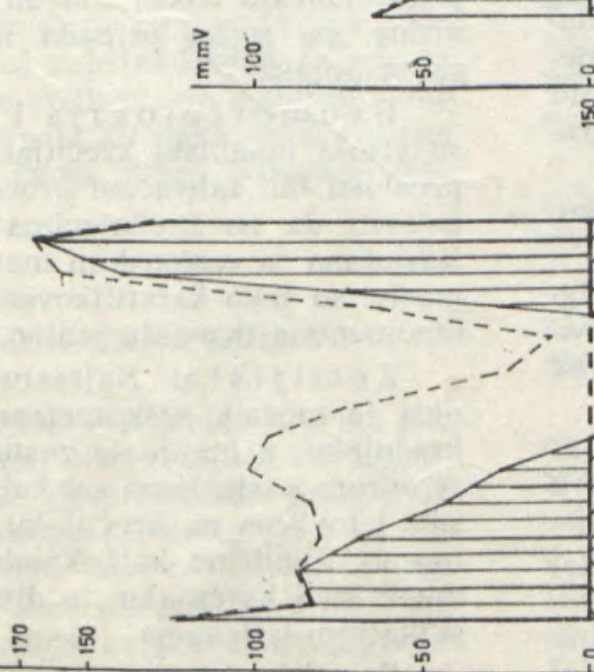

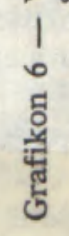


Odlike ovih zemljišnih kombinacija su visoka površinska stjenovitost. U nižim dijelovima mezo reljefa znatno je učešće rožnjačkog skeleta, pa se sreću distrični kambisoli i opodzoljena zemljišta.

Realna šumska vegetacija: Preovlađuju šume bukve i jele sa smrčom (Piceo - Abieti - Fagetum), sa kojima su značajno zastupljene i različite sekundarne fitocenoze: šume bijelog bora i smrče (jele) (Piceo - Pinetum illyricum), šume jele i smrče (Abieti - Piceetum illyricum) i šume bukve (Fagetum montanum).

Manje površine zauzimaju hrastove fitocenoze: šuma kitnjaka (Quercetum petraeae montanum), kitnjaka i cera (Quercetum petraeae - cerris), kitnjaka i običnog graba (Querco - Carpinetum), te brdske šume lužnjaka (Quercetum roboris montanum).

U kanjonima vodotoka i na litičastim otsjecima padina zastupljene su termofilne fitocenoze, često reliktnog karaktera: šume crnog bora (Pinetum nigrae calcicolum), šume bijelog graba (Carpinetum orientalis), šume crnog graba (Orno - Ostryetum) i termofilne šume bukve (Ostryo - Fagetum).

U ovom rejonu skoncentrisana su pretežno nalazišta tercijarne Pančićeve omorike (s lijeve i desne strane kanjona Drine).

Potencijalna šumska vegetacija: Najveće površine rejona pripadaju klimaregionalnoj šumi bukve i jele sa smrčom, a znatno manje bez smrče (smrča ovdje takođe izostaje u sjevernom dijelu rejona, južno od Sprečke kotline zbog panonskih klimatskih uticaja).

Ostale fitocenoze trajnih stadija vegetacije imaju, više-manje ostrvski položaj unutar ovog klimaregionalnog pojasa.

\subsection{Jugoistočnobosansko područje}

Položaj: Zauzima planinske i subalpinske predjele jugoistočne Bosne, južno od Sarajevskog polja do granice sa SR Crnom Gorom. Sa istoka je omeđeno linijom koja slijedi od Ravne planine i Jahorine, kanjonom Bistrice i dolinom Drine do Śćepan polja. Jugozapadnu granicu predstavljaju najviši grebeni Bjelašnice, Treskavice, Zelengore i Volujaka (ovi grebeni čine granicu između unutrašnjih Dinarida i mediteransko-dinarske oblasti).

Visinski, područje se nalazi od 500 do $2.386 \mathrm{~m}$ (vrh Maglića), ali preovlađuju tereni od 1.000 do $1.600 \mathrm{~m}$ nadmorske visine.

Klima: Prema prosjeku srednjih vrijednosti temperature, padavina, relativne vlage (stanica Suhe, Kalinovika, Bjelašnice i Igmana), u ovom području je izražen uticaj mediteranske klime, jer oko $47 \%$ padavina je u vegetacionom periodu. Međutim, stanica Bjelašnice pokazuje, u zimskom periodu od novembra do maja, jak uticaj kontinentalne klime (tabela 4 i grafikon 5 i 6 ).

Odnos padavina i evapotranspiracije, u prosjeku, je povoljan $(1,25)$.

Vegetacioni period traje od 100 do 170 dana (Igman i Suha). Izuzetno, na najvišim planinskim vrhovima Bjelašnice i Maglića vegetacioni period ( $\mathrm{T}$ iznad $\left.10^{\circ} \mathrm{C}\right)$ u prosjeku traje samo nekoliko dana.

Geomorfologija i geološka građa: Ovo područje visokih planina, na kojima ima tragova glacijalnih procesa, izgrađeno je uglavnom od krečnjačko-dolomitnih stijena, a manje verfenskih pješčara i glinaca.

Z emljišta: Preovladavaju različite zemljišne kombinacije tipa mozaika na krečnjaku i dolomitu, a manje distriéni kambisoli na kiselim silikatnim supstratima.
Realna šumska vegetacija: Dominantna je šuma bukve i jele sa smrčom, (Piceo - Abieti Fagetum). Na manjim površinama, zastupljena je i šuma bukve i jele bez smrče koja izostaje zbog prodora mediteranskih uticaja (na rubu pojasa prema mediteransko-dinarskoj oblasti - sliv Hrčavke, izvorišni dio Govze, Babin do na Bjelašnici).

Unutar ovih šuma rasprostranjene su sekundarne fitocenoze jele i smrče (pretežno Abieti - Piceetum illyricum), bijelog bora i smrče (jele) (Piceo - Pinetum illyricum), zatim šume bukve (Fagetum montanum illyricum).

Za subalpinsku zonu karakteristična je zastupljenost šume bukve (Fagetum subalpinum) i klekovine bora (Pinetum mugi).

Osim ovih zastupljene su, na hladnijim staništima, subalpinske šume smrče (Piceetum subalpinum).

$\mathrm{Na}$ staništima u kanjonima vodotoka rasprostranjene su reliktne šume crnog bora (Pinetum nigrae calcicolum), šume crnog graba (Orno-Ostryetum), termofilne šume bukve (Ostryo-Fagetum) i šume javora i lipa (Aceri-Tilitum mixtum).

Hrastove fitocenoze, šume kitnjaka i cera (Quercetum petraeae - cerris) - površ oko Kalinovika, zatim šume kitnjaka i graba (Querco - Carpinetum), šume kitnjaka (Quercetum petraeae montanum), uglavnom su vezane za niže predjele prema Sarajevskom polju, te za slivove Željeznice i Dobropoljske rijeke.

Potencijalna šumska vegetacija: Područje najvećim dijelom pripada klimaregionalnim šumama bukve i jele sa smrčom, a manjim dijelom šumama bukve $i$ jele bez smrče (navedene u realnoj vegetaciji). Subalpinski pojas većim dijelom predstavlja staništa šume bukve, sa klekovinom bora, u najvišim zonama, te subalpinske šume smrče intrazonalnog karaktera.

Neznatnim dijelom područje pripada (prema jugoistočnom rubu Sarajevskog polja) klimazonalnoj fitocenozi kitnjaka i običnog graba.

Kanjoni vodotoka pripadaju staništima ranije navedenih reliktnih fitocenoza. Male površine recentnih fluvisola predstavljaju staništa sive johe (Alnetum incanae), odnosno šuma vrba (Salicetum).

\subsubsection{Igmansko-zelengorski rejon}

Položa j: Obuhvata planinsko-subalpinske predjele od obronaka Bjelašnice, Igmana i Trebevića, na sjeverozapadu, do granice sa SR Crnom Gorom, na jugoistoku.

Prostire se od 500 do $2.386 \mathrm{~m}$ (vrh Maglića) ali preovladavaju tereni između 1.000 i $1.600 \mathrm{~m}$ nadmorske visine, pa rejon pripada izrazito planinsko-subalpinskom pojasu.

Geomorfologija i geolosk a građa: Ovo su visoki planinski krečnjački masivi čiji su vrhovi u prošlosti bili zahvaćeni procesima glacijacije, što može usloviti da na krečnjacima imamo duboka zemljišta izmješana sa verfenskim materijalom. Inače krečnjački masivi su jako karstifikovani sa gotovo svim karstnim fenomenima (izostaju jedino kraška polja).

$\mathrm{Z}$ e m l j i št a: Najzastupljenija kartografska jedinica je mozaik kalkomelanosola i kalkokambisola na krečnjaku, a manje je zastupljena složenija zemljišna struktura sastavljena od kalkomelanosola, kalkokambisola i luvisola na krečnjaku, kao i kompleks (odnosno mozaik) rendzine, kalkokambisola i kalkomelanosola na dolomitu i krečnjaku, te distrični kambisol na kiselim silikatnim stijenama.

Zemljišta karakteriše stjenovistost površine, skeletnost profila, plitkoća, što uslovljava pojačanu kserotermnost nekih staništa. 
Realna šumska vegetacija: Preovlađuju šume bukve $\mathrm{i}$ jele sa smrčom (Piceo - Abieti - Fagetum), a znatno manje šume bukve i jele bez smrče (uz rubni pojas ka mediteransko-dinarskoj oblasti). Unutar ovih zastupljene su sekundarne fitocenoze jele i smrče (Abieti - Piceetum illyricum), bijelog bora i smrče (jele) (Piceo - Pinetum illyricum), šume bukve (Fagetum montanum).

Manje površine šuma smrče (Piceetum montanum inversum) su intrazonalnog karaktera.

U subalpinskom pojasu rasprostranjene su fitocenoze: Fagetum subalpinum, Pinetum mugi i Piceetum subalpinum. U nižim, toplijim položajima: Querceturn petraeae - cerris, Qurcetum petraeae montanum, Querco-Carpinetum. U kanjonima vodotoka: Pinetum nigrae calcicolum, Orno-Ostryetum, Ostryo-Fagetum, Aceri-Tilietum mixtum.

Potencijalna šumska vegetacija: Najvećim dijelom rejon pripada šumama bukve $i$ jele sa smrčom, te subalpinskim šumama bukve, odnosno klekovine bora. Unutar ovih karakteristična staništa zauzimaju intrazonalne šume'smrče, odnosno termofilne fitocenoze specifičnih staništa u kanjonima (navedene su prethodno).

Neznatne površine ovog rejona pripadaju hrastovim staništima.

\subsubsection{Trnovski rejon}

Položaj: Obuhvata gornje dijelove sliva Željeznice, odnosno Dobropoljske rijeke i Crne rijeke. Izrazito je planinsko područje u visinskom intervalu od 800 do $1.450 \mathrm{~m} \mathrm{n}$. v.

Geomorfologija i geološka građa: Visokoplaninski masivi su izgrađeni uglavnom od verfenskih sedimenata (glinaca i pješčara), paleozojskih sedimenata (pješčara, škriljaca i rožnjaka) te od krečnjaka.

Z e mlji šta: Najzastupljeniji tip zemljišta je distrični kambisol na kiselim silikatnim stijenama, a manje mozaik kalkomelanosola i kalkokambisola na krečnjaku.

Zemljišta su povoljnijih fizičko-hemijskih svojsta$\mathrm{va}$, pa se površine relativno blažih nagiba koriste $\mathrm{u}$ poljoprivredne svrhe.

Realna šumska vegetacija: Najveće površine zauzimaju šume bukve (Luzulo-Fagetum), unutar kojih su se zadržale manje površine šuma bukve $i$ jele sa smrčom.

Orografski uslovljene, na toplim položajima, rasprostranjene su šume kitnjaka (Quercetum petraeae montanum).

Potencijalna šumska vegetacija: Rejon pripada klimaregionalnoj zajednici bukve $i$ jele sa smrčom unutar koje manje enklave, na toplijim položajima pripadaju šumama hrasta kitnjaka; recentni aluviji predstavljaju staništa šuma vrbe, odnosno sive johe.

\section{MEDITERANSKO-DINARSKA OBLAST}

Položa j: Zauzima dijelove Dinarida koji su pod uticajem mediteranske klime, obuhvatajući Hercegovinu i dijelove Bosne. Prema sjeverozapadu proteže se do podnožja Plješevice odnosno Grmeča, gdje se još osjećaju prodori mediteranske klime dolinom rijeka Krke, Zrmanje, Unca i Une kao i planinskim prevojima. $\mathrm{Na}$ sjeveroistoku graniči planinskim grebenima i prevojima (uglavnom vododjelnicom Jadranskog i Crnomorskog sliva).
U visinskom intervalu proteže se od razine mora, pa do brojnih masiva, čija visina prelazi preko $2.000 \mathrm{~m}$ nadmorske visine.

K 1 i ma: Citava ova oblast je pod uticajem mediteranske klime (Tabela 5 i grafikon 7 i 8). Uticaj toplotnog režima naglo slabi sa porastom nadmorske visine planinskih masiva, ali se uticaj padavinskog režima maritimnog karaktera jako osjeća i na sjevernoj, planinskoj granici oblasti prema unutrašnjim Dinaridima.

Zavisno od udaljenosti od mora, kao i od nadmorske visine, a naročito od položaja pojedinog predjela (otvorenost prema moru) jako varira temperatura, pa prema tome i opšti karakter klime je dosta različit. Tako na primjer $\mathrm{u}$ kraškim poljima $\mathrm{u}$ toku zimskog perioda izražene su inverzije temperatura. $\mathrm{Za}$ razliku od klime ostalih oblasti, ovdje klimu karakteriše česta pojava jakih i slapovitih vjetrova (bure).

Geomorfologija i geološka građa: Ova oblast zauzima gotovo cijele vanjske Dinaride, $\mathrm{tj}$. goli krš pa se od morske razine vrlo strmo izdiže do visokih planinskih masiva. Cijela površina je jako karstifikovana i zastupljeni su svi, veoma brojni fenomeni karstne erozije. Dominiraju kredni i jurski krečnjaci i dolomiti, a manje su zastupljeni flišoliki i drugi sedimenti. U višim planinskim predjelima prisutni su oblici glacijalne erozije.

$\mathrm{Z}$ em lj išta: Karakteristike zemljišnog pokrivača, posebno za šumske površine, je vrlo visoki stepen površinske stjenovitosti. Zemljišne kombinacije, koje zauzimaju mjestimično samo do $10 \%$ površine, najčešce obuhvataju samo prva dva člana serije zemljišta na krečnjaku (kalkomelanosol i kalkokambisol). U toplijem, nižem, dijelu područja u klasi A-(B)-R zemljišta, umjesto kalkokambisola, češće se sreće terra rossa. Mozaičnost, kontrastnost i svojstva članova zemljišnih kombinacija zavise u mnogome od načina slojanja krec̈njaka prema padini.

Fitogeografska pripadnost: Pečat vegetaciji ove oblasti daju više ili manje izraženi uticaji mediteranske klime. Uski obalni pojas uz Jadransko more predstavlja područje zimzelene vegetacije klimazonalne zajednice Orno - Quercetum ilicis, koja je danas predstavljena degradacionim oblicima - makije i gariga.

$\mathrm{Na}$ uski pojas zimzelene vegetacije nastavlja se klimazonalna zajednica medunca i bijelog graba (Querco - Carpinetum orientalis $=$ Carpinetum orientalis).

Za višu zonu krša u ovoj oblasti karakteristična je zajednica medunca (cera) i crnog graba (Querco Ostryetum carpinifoliae).

Specifičnost vegetacije $u$ ovom dijelu oblasti je zastupljenost reliktne tercijerne fitocenoze makedonskog hrasta (Quercetum trojanae), te nekih flornih elemenata tercijarne starosti (Petteria ramentacea, Corylus colurna, Moltkaea petraea, i drugih).

Unutar submediteranskog dijela Hercegovine karakteristična je pojava šuma sladuna i cera (Quercetum confertae adriaticum).

Cerove fitocenoze (Orno - Quercetum cerris) zahvataju više dijelove Hercegovine i zapadne dijelove Bosne koji pripadaju ovoj oblasti.

Termofilne šume bukve (Seslerio-Fagetum) rasprostiru se u višim dijelovima oblasti i najčešce su ostrvskog položaja.

U kanjonima rijeka zastupljene su reliktne fitocenoze crnog graba (Seslerio - Ostryetum), crnog bora (Pinetum nigrae submediterraneum). Na specifičnim staništima se nalaze zajednice javora i lipa (Aceri Tilietum mixtum), medvjeđe lijeske i oraha (Juglando - Coryletum), itd. 


$$
L A
$$




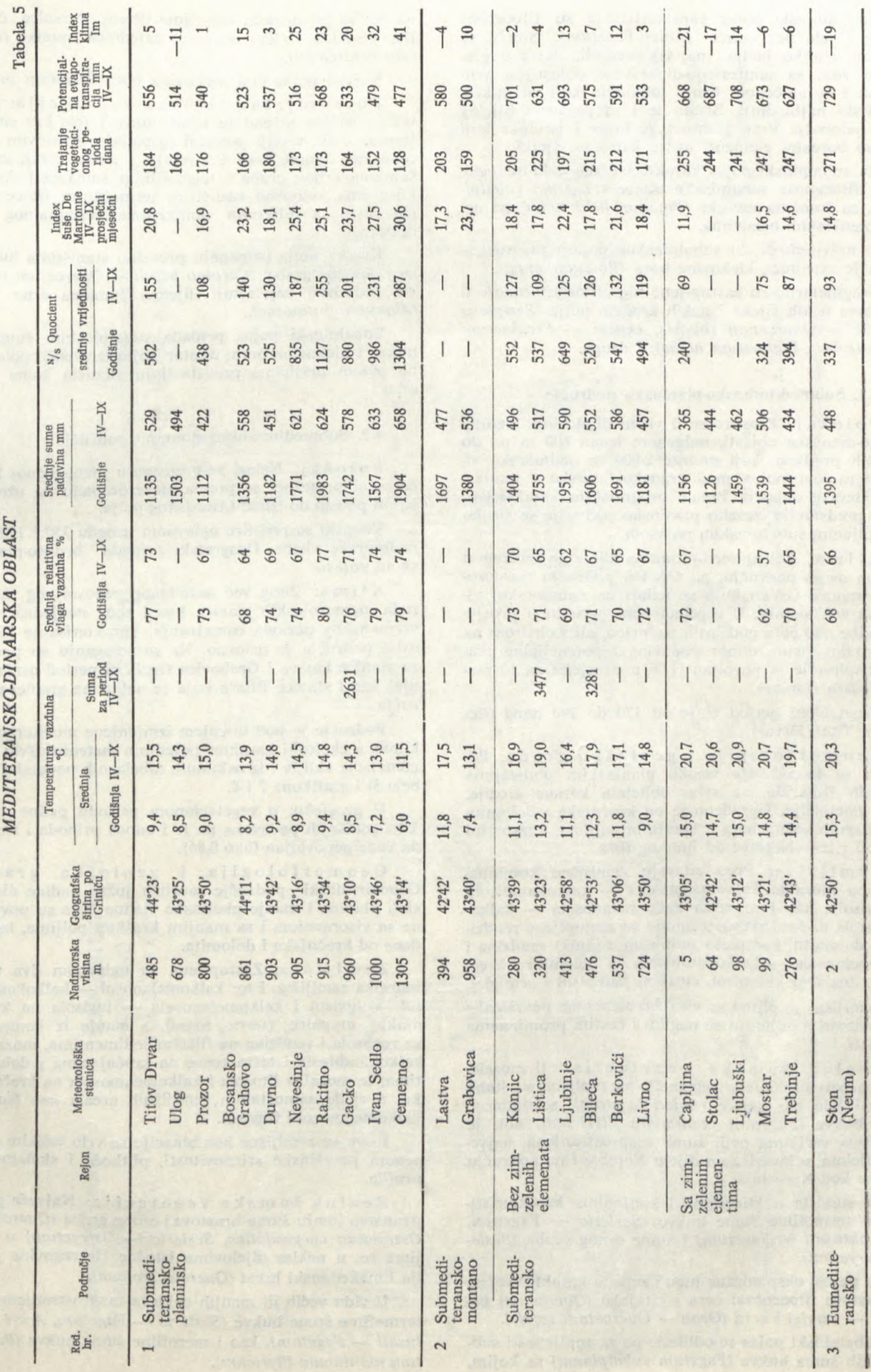


Za planinski pojas karakteristične su fitocenoze bukve i jele bez smrče (Abieti-Fagetum). Smrča se izuzetno rijetko javlja (najviši predjeli, često u graničnoj zoni sa unutrašnjo-dinarskom oblasti) u vrlo malom i ograničenom broju lokaliteta koji su mikroklimatski najhladniji. Slično je i sa pojavom bijelog bora (područje Vran planine), te breze i jarebike koji su kao borealni elementi ovdje izuzetno rijetki.

Za subalpinski pojas karakteristična je klimaregionalna fitocenoza subalpinske bukve (Fagetum subalpinum), sa šumama munike (Pinetum heldreichii) na nekim planinskim masivima.

U najvišem dijelu subalpinskog pojasa rasprostranjena je zajednica klekovine bora (Pinetum mugi).

Fragmetarno su zastupljene higrofilne fitocenoze u dolinama nekih rijeka i nekih kraških polja (Periploco graecae - Quercetum roboris, Leucoi - Fraxinetum angustifoliae, Poputetum albae), i druge.

\subsection{Submediteransko-planinsko područje}

Položa j: Prostire se u višim dijelovima mediteransko-dinarske oblasti, uglavnom iznad $800 \mathrm{~m}$ pa do najviših predjela, koji prelaze $2.000 \mathrm{~m}$ nadmorske visine (granični pojas mediteransko-dinarske i unutrašnjodinarske oblasti). Prema orografskim karakteristikama predstavlja izrazito planinsko područje sa široko zastupljenim subalpinskim pojasom.

K li ma: Uticaj mediteranske klime je izražen u cijelom ovom području, pa čak i u području meteorološke stanice Gacko koja se nalazi na nadmorskoj visini od 960 metara. $\mathrm{U}$ vegetacionom periodu u prosjeku padne oko $36 \%$ godišnjih padavina, ali s obzirom na nadmorsku visinu odnos padavina i potencijalne evapotranspiracije je povoljan (1,06 u prosjeku za 10 meteoroloških stanica).

Vegetacioni period traje od 120 do 190 dana (Čemerno, Titov Drvar).

Geomorfologija i geološka građa: Područje se karakteriše visoko planinskim obilježjima vanjskih Dinarida, sa svim oblicima karsne erozije, kao i glacijacije. Izgrađeno je od krečnjaka i dolomita i tercijernih sedimenata u karstnim poljima, a izvorišni predjeli rijeke Neretve od jurskog fliša.

$\mathrm{Z}$ em ljišta: Preovladavaju zemljišne kombinacije tipa mozaika kalkomelanosola - kalkokambisola - luvisola, kao i mozaika kalkomelanosola - kalkokambisola na krečnjaku, a manje su zastupljene rendzine na dolomitu, kompleks (odnosno mozaik) rendzina i kalkomelansola - kalkokambisola na dolomitu i krečnjaku, distriěni kambisol, eutrični kambisol i semiglej.

Zemljišta su plitka sa visokim stepenom površinske stjenovitosti a odlikuju se naglim i čestim promjenama vlažnosti.

Realna šumska vegetacija: U mozaičnom rasporedu šumske vegetacije zastupljene su šume bukve i jele bez smrče (Abieti-Fagetum), sekundarne šume bukve (Fagetum montanum illyricum), dok je acidofilna varijanta ovih šuma rasprostranjena, najvećim dijelom, u izvorišnom dijelu Neretve i na području Trusine kod Nevesinja.

Za staništa u klisurama i kanjonima karakteristične su termofilne šume bukve (Seslerio - Fagetum, Aceri obtusati - Fagetum) i šume crnog graba (Seslerio-Ostryetum).

Za površi eksponirane jugu i zapadu karakteristične su hrastove fitocenoze: cera i kitnjaka (Quercetum petraeae - cerris) i cera (Orno - Quercetum cerris).

Subalpinski pojas se odlikuje po zastupljenosti sub. alpinskih šuma bukve (Fagetum subalpinum) sa kojim, na nekim planinskim masivima (Prenj, Cvrsnica, Cabulja, Visočica, Orjen) alternira zajednica munike (Pinetum heldreichii).

Najviši pojas čini klekovina bora (Pinetum mugi).

Potencijalna šumska vegetacija: Najveće površine pripadaju šumi bukve $i$ jele bez smrče. Unutar ovih, topliji položaji pripadaju hrastovim fitocenozama (šume cera i kitnjaka i šume cera), zatim šumama crnog graba i termofilnim šumama bukve u klisurama, odnosno različitim termofilnim fitocenozama često sa reliktnim obilježjima, refugijalnog karaktera.

Kraška polja pripadaju pretežno staništima lužnjaka i običnog graba, (Carpino betuli - Quercetum roboris), odnosno najvlažniji dijelovi šumama crne johe (Alnetum glutinosae).

Subalpinski pojas pripada subalpinskim šumama bukve i klekovine bora, unutar kojih izraženiji položaji na nekim masivima predstavljaju staništa šuma munike.

\subsection{Submediteransko-montano područje}

Položa j: Nalazi se pretežno u jugoistočnoj Hercegovini protežući se prema sjeverozapadu na užem i šrem potezu do iznad Livanjskog polja.

Visinski se prostire uglavnom između 750 i $1200 \mathrm{~m}$ nadmorske visine. Orografski pripada brdsko-planinskom pojasu.

K 1 i ma: Zbog već navedenog nepovoljnog rasporeda meteoroloških stanica kao i zbog neujednačenog vremenskog perioda osmatranja, karakterisanje klime ovog područja je uslovno. $\mathrm{Na}$ raspolaganju su podaci za stanice Lastva i Grabovica (različiti period osmatranja) kao i stanice Bileća koja se nalazi na granici područja.

Područje je pod uticajem izmjenjene mediteranske klime, a ekološki karakter pojedinih meteoroloških elemenata je vidljiv i iz oskudnih tabelarnih podataka (tabela 5) i grafikona 7 i 8 .

$\mathrm{U}$ prosjeku, u vegetacionom periodu padne oko $33 \%$ godišnjih padavina, pa je $\mathrm{i}$ odnos prihoda $\mathrm{i}$ rashoda vode nepovoljan (oko 0,86 ).

Geomorfologija i geološka građa: Geomorfološki područje zauzima južne padine dinarskih planina i manje planinske cjeline koje su povezane sa visoravnima i sa manjim kraškim poljima, izgrađene od krečnjaka i dolomita.

Z emljišt a: Zastupljena su uglavnom dva tipa mozaika zemljišta, i to: kalkomelanosol - kalkokambisol - luvisol i kalkomelanosola - luvisola na krečnjaku; crvenice (terra rossa), a manje iz kompleksa regosola i rendzina na flišnim sedimentima, mozaika kalkokambisola i terra rosse na krečnjacima i dolomitima; te mozaika litosola i kalkomelanosola na krečnja$\mathrm{ku}$, a rjeđe samostalnih zemljišnih areala kao što je kalkomelanosol i fluvisol.

I ovo su zemljišne kombinacije sa vrlo velikim stepenom površinske stjenovitosti, plitkoće i skeletnosti profila.

Realna šumska veget a cija: Najveće prostranstvo imaju šume hrastova i crnog graba (QuercoOstryetum carpinifoliae, Seslerio - Ostryetum) u kojima se, $\mathrm{u}$ nekim dijelovima istočne Hercegovine javlja i makedonski hrast (Quercus trojana).

U vidu većih ili manjih enklava rasprostranjene su termofilne šume bukve (Seslerio - Fagetum, Aceri obtusati - Fagetum), kao i mezofilne šume bukve (Fagetum montanum illyricum). 

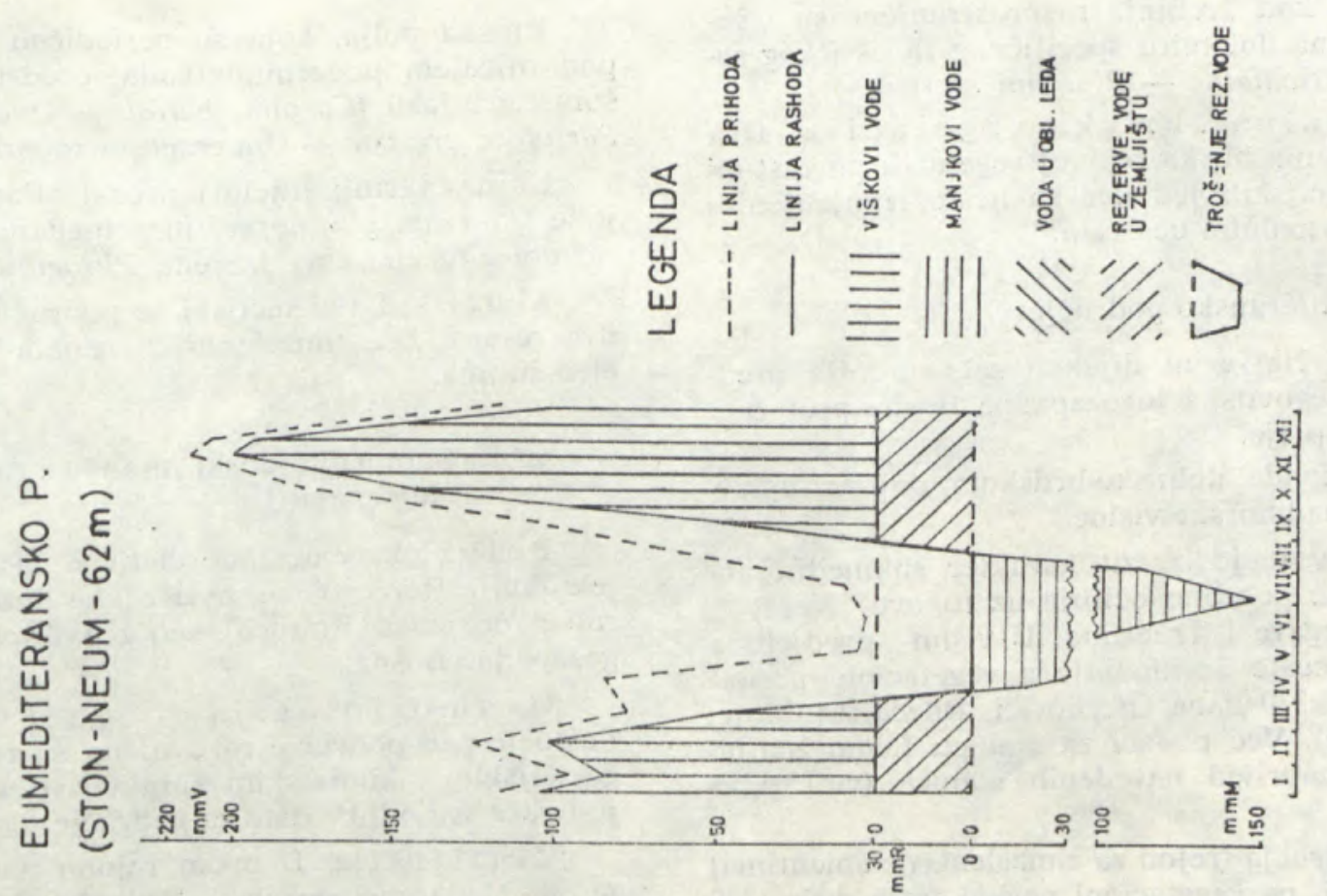

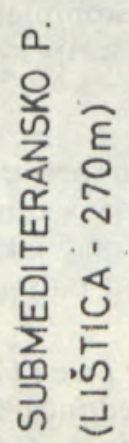
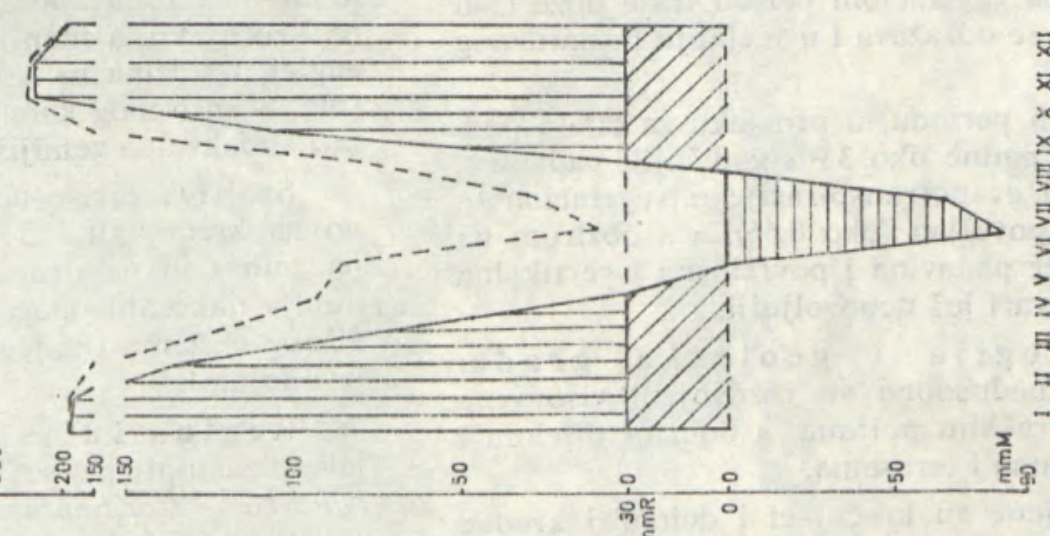

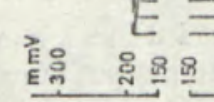

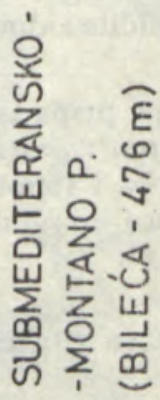

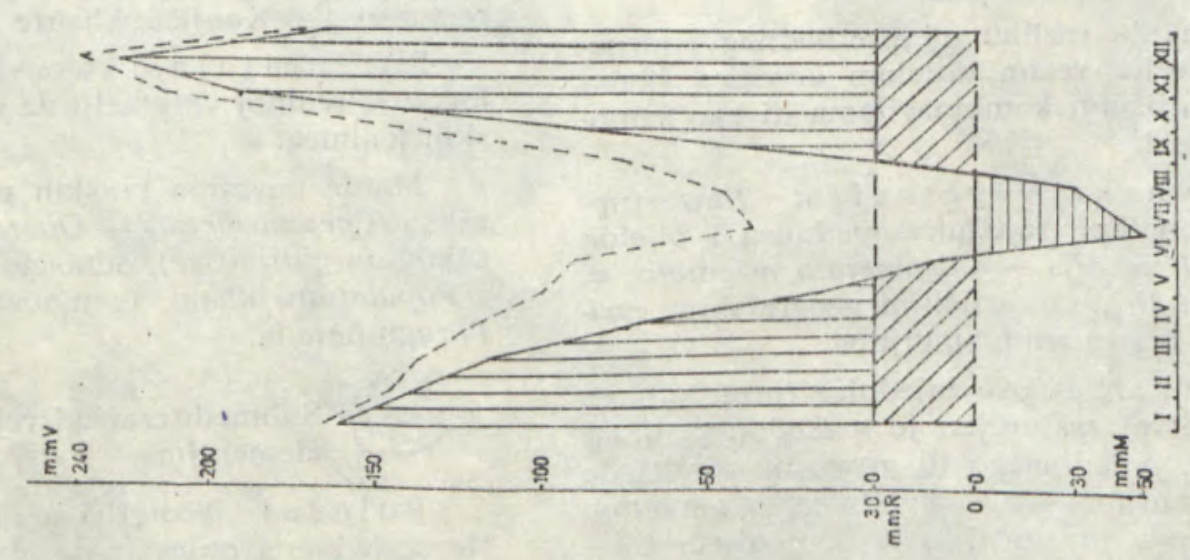

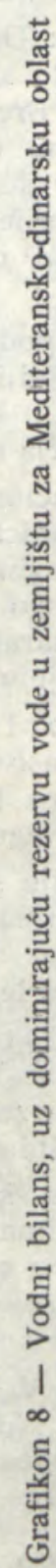
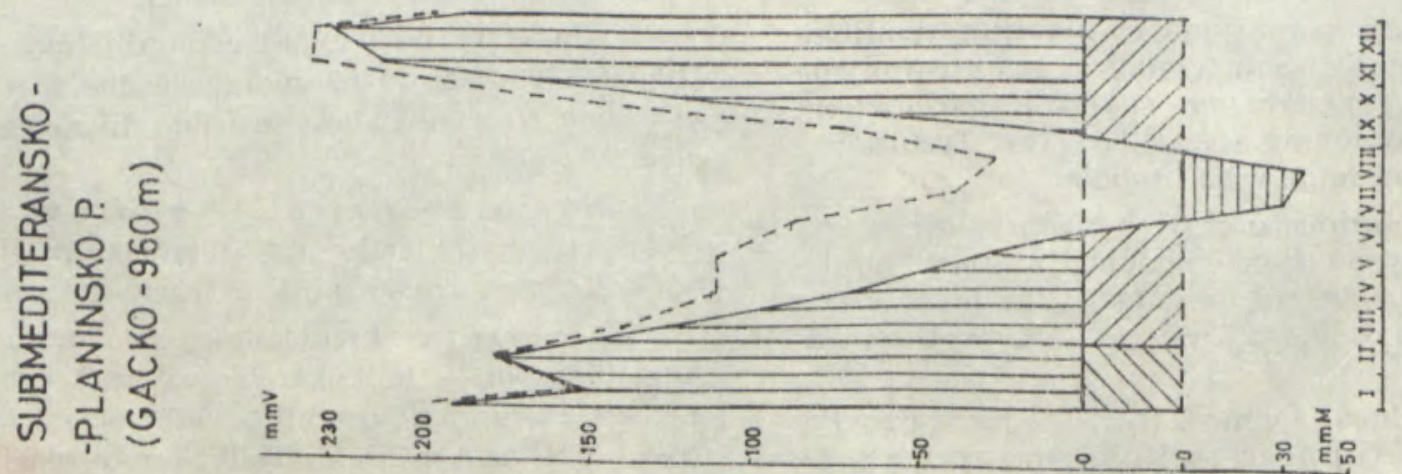

ฉ 
Oko Lastve kod Trebinja rasprostranjene su i šume crnog bora na dolomitu specifičnog florističkog sastava (Erico verticillatae - Pinetum nigrae).

Potencijalna šumska vegetacija: Ova vegetacija je veoma bliska realnoj vegetaciji po zastupljenosti vegetacijskih jedinica sa nešto izmijenjenim njihovim procentualnim učešćem.

\subsection{Submediteransko područje}

Položaj: Najvećim dijelom zahvata niže predjele donje Hercegovine i jugozapadne Bosne protežući se uz Livanjsko polje.

Visinski pripada dolinsko-brdskom pojasu, uglavnom do $750 \mathrm{~m}$ nadmorske visine.

Klima: Ovdje je izrazit karakter submediteranske klime što se posebno očituje uz tokove Neretve, Trebišnjice, Bregave i Trebižata. U višim predjelima (iznad $300 \mathrm{~m}$ ) nešto je hladnije a vegetacioni period traje od 200 do 230 dana (Berkovići, Bileća, Ljubinje, Lištica i Konjic). Već podaci za stanieu Livno znatno odstupaju od naprijed navedenih stanica (vidi tabelu 5).

Niži dio područja (rejon za zimzelenim elementima) je znatno topliji, pa vegetacioni period traje duže ( 240 - 260 dana), a što se odražava i u trajanju bezmraznog perioda (tabela 6).

U vegetacionom periodu, u prosjeku za cijelo područje (11 stanica), padne oko $33 \%$ godišnjih padavina. Odnos padavina i evapotranspiracije u vegetacionom periodu je vrlo nepovoljan (oko 0,66 ), a s obzirom na pljuskoviti karakter padavina i površinska i vertikalna oticanja, on je u stvari još nepovoljniji.

Geomorfologija i geološka građa: Planinski masivi međusobno su razdvojeni visoravnima, zaravnima i kraškim poljima, a dobrim dijelom i aluvijalnim ravninama i terasama.

Najvažnije stijene su krečnjaci i dolomiti kredne i jurske starosti, a u poljima i aluvijalnim ravnima zastupljeni su tercijarni sedimenti i recentni aluviji. Lokalno ima i lesolikog materijala.

$\mathrm{Z}$ e mljišta: $\mathrm{Za}$ razliku od prethodnog područja ovo se karakteriše većim udjelom crvenica (terra rossa), bilo u zemljišnim kombinacijama ili kao samostalni zemljišni areal.

Realra šumska vegetacija: Najzastup. ljenija je klimazonalna zajednica medunca $i$ bijelog graba (Querco pubescentis - Carpinetum orientalis $=$ Carpinetum orientalis), sa razlicitim geografskim varijantama, odnosno regresivnim stadijima.

U većem dijelu areala ove zajednice (pretežno sa lijeve strane Neretve) zastupljen je makedonski hrast (Quercus trojana), pojedinačno ili grupimično. Rjeđe gradi cjelovite sastojine svoje zajednice (Quercetum trojanae), kao što je to slučaj u južnom dijelu Crne Gore i u Makedoniji.

$\mathrm{Na}$ zaravnjenim položajima sa dubljim zemljištitem, najčešće ilimerizovanih crvenica, rasprostranjene su šume sladuna (Quercetum confertae adriaticum). $\mathrm{Na}$ recentnim fluvisolima (oko Neretve, Trebižata i Bregave) susreću se šume vrba i topola.

$\mathrm{Na}$ višim položajima, u ekstremnijim uslovima staništa, zastupljene su šume medunca i crnog graba (Querco - Ostryetum carpinifoliae), te šume crnog graba sa jesenjom šašikom (Seslerio - Ostryetum carpinifoliae).

Potencijalna šumska vegetacija: Podudarna je u najvećoj mjeri sa jedinicama realne vegetacije uz različite odnose $u$ pogledu učešća pojedinih jedinica.
Kraška polja, koja su periodično plavljena ili su pod uticajem podzemnih voda, predstavljaju staništa šuma lužnjaka (Carpino betuli - Quercetum roboris, Periploco graecae - Quuercetum roboris).

Najmočvarniji dijelovi predstavljaju staništa crne johe (Alnetum glutinosae) ili pripadaju različitim močvarnim fitocenozama iz reda Phragmitetalia.

Klimatski i vegetacijski se područje diferencira na dva rejona: bez zimzelenih elemenata i sa zimzelenim elemenitma.

\subsection{1: Submediteranski rejon bez zimzelenih elemenata}

Položaj: Zauzima relativno više obodne predjele donje Hercegovine, uvlačeći se dublje dolinom Neretve (do iznad Konjica) kao i najtoplije predjele jugozapadne Bosne.

Geomorfologija i geološka građa: Pošto je ovo područje razdvojeno na rejone prema vegetacijskim i klimatskim karakteristikama, za ovaj rejon važe sve odlike date za područje.

$\mathrm{Zemljišta:} \mathrm{U} \mathrm{ovom} \mathrm{rejonu} \mathrm{najzastupljeniji} \mathrm{je}$ mozaik kalkomelanosola - kalkokambisola - luvisola na krečnjaku, a manji značaj imaju fluvisoli, semiglej, euglej, rendzina na dolomitu i kompleks kalkomelanosola - eutričnog kambisola na seriji krečnjaka i laporca i subakvalna zemljišta.

Svojstva zavise od toga da li je zemljište razvijeno na krečnjaku i dolomitu (kamenita, plitka, skeletna, suha) ili na drugim vrstama sedimenata (tada su dublja, jako antropogenizirana, pod jakim uticajem suvišnog vlaženja i najčešće su pod poljoprivrednom proizvodnjom).

Realna šumska vegetacija: Najvećim dijelom zastupljene su šume medunca i bijelog graba (Querco - Carpinetum orientalis $=$ Carpinetum orientalis), sa kojim su, u nekim predjelima, interpolirane šume crnog graba (Querco - Ostryetum carpinifoliae), odnosno šume crnog bora (Pinetum nigrae submediter. raneum) oko Konjica, klisure Neretve, Prozora.

Potencijalna šumska vegetacija: Analogna je realnoj vegetaciji uz različite odnose vegetacijskih jedinica.

Manje površine kraških polja pripadaju šumi lužnjaka (Carpino betuli - Quercetum roboris), crne johe (Alnetum glutinosae), odnosno vrba i topola (Salicetum i Populetum albae), te močvarnoj vegetaciji iz reda Phragmitetalia.

4.3.2 Submediteranski rejon sa zimzelenim elementima

Položaj: Proteže se nižim dijelovima donje Hercegovine, s obje strane Neretve dopirući uz Neretvu do kanjona Neretve (Salakovac).

Visinski se nalazi, najvećim dijelom, između 50 (100) do 400 (500) m nadmorske visine, a najniži dijelovi doline Neretve nalaze se ispod $10 \mathrm{~m}$ nadmorske visine.

Geomorfologija i geološka građa: Ovaj reon karakterišu niži planinski masivi izgrađeni od krečnjaka, kraška polja i aluvijalne ravni.

$\mathrm{Z}$ e mlj išt a: Preovlađuje, uglavnom, mozaik kalkomelanosola - kalkokambisola na krečnjaku, a manje su zastupljeni mozaik kalkomelanosola - terra rossa, isto na krečnjaku; kalkokambisola i terra rossa kao samostalnih zemljišnih areala, rendzine na karbonatnom materijalu. 


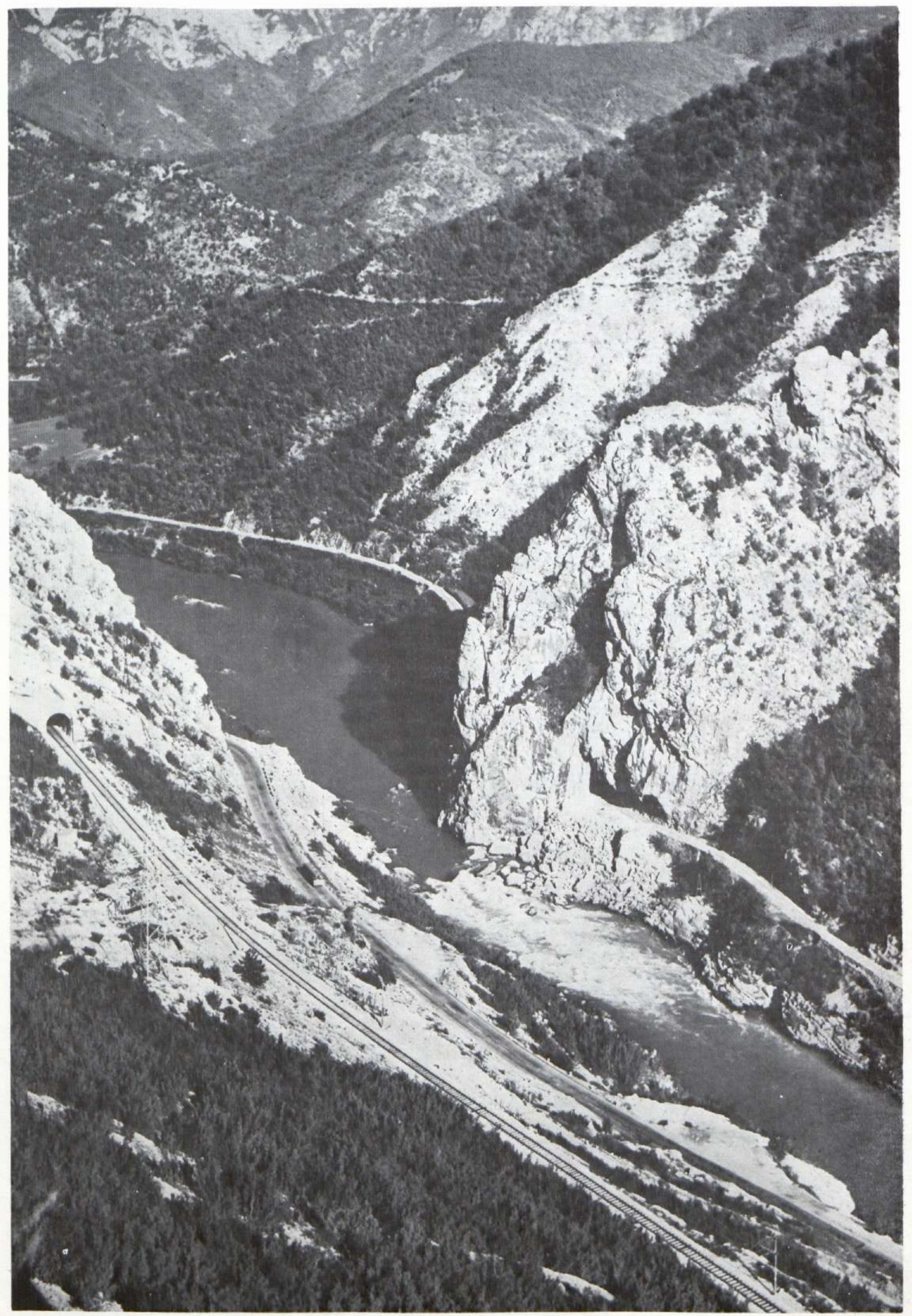

Slika 4 - Kserotermofilne šume i šikare bijelog, odnosno crnog graba u srednjem dijelu kanjona Neretve (foto: c. Silić) 



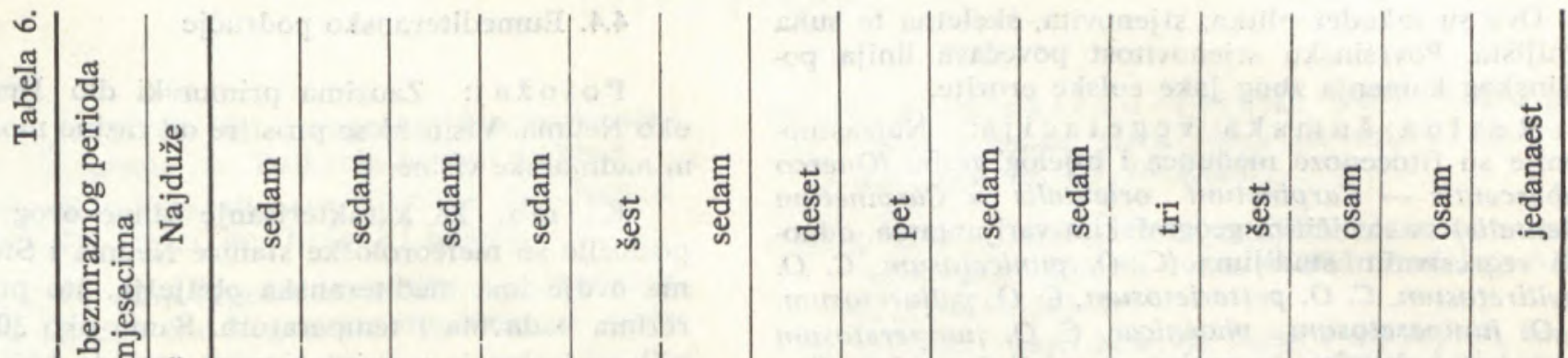

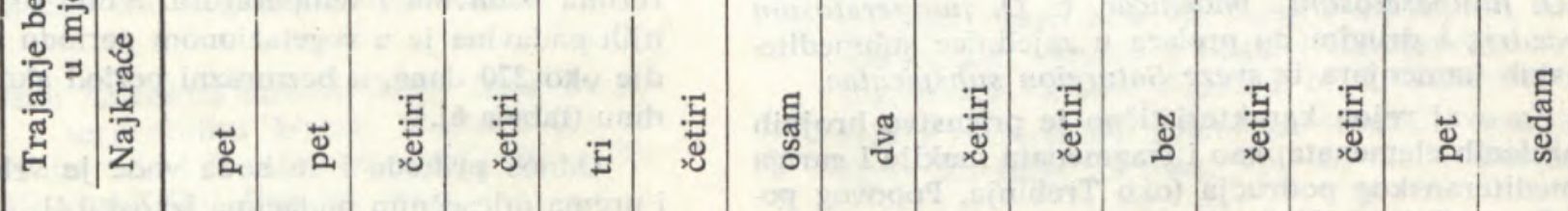

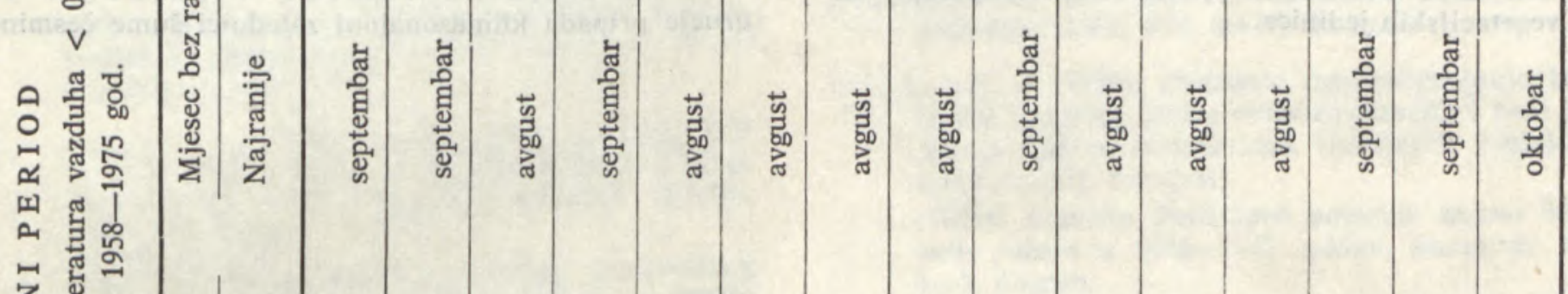

乙

N

然

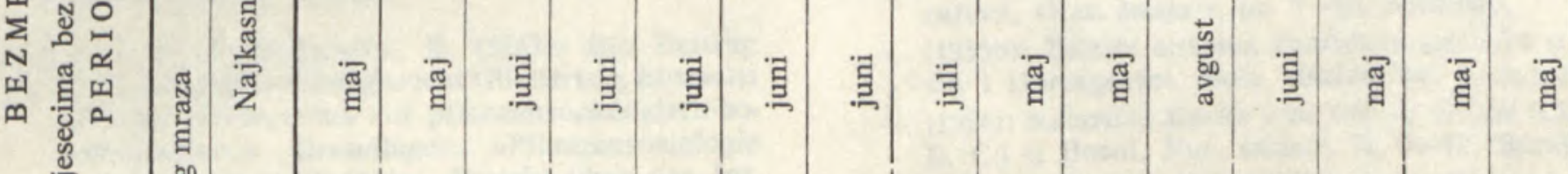

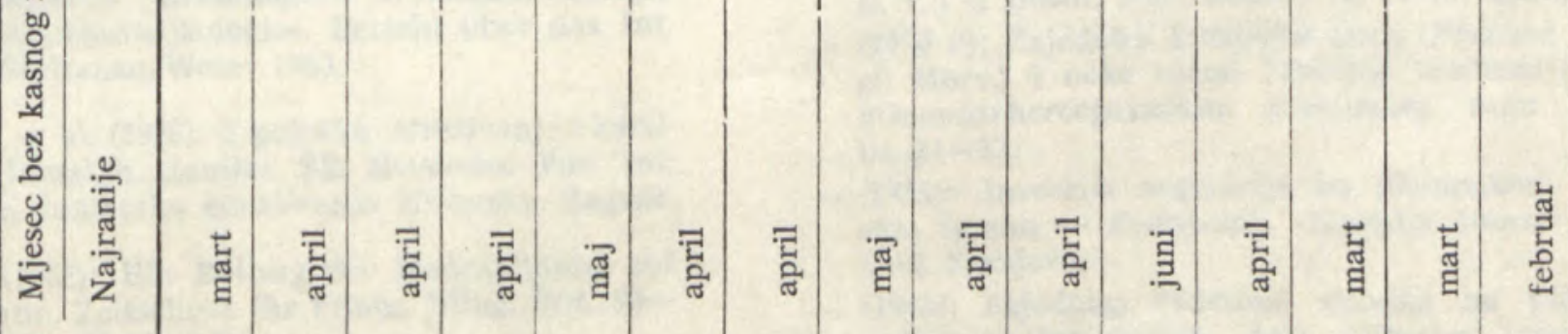

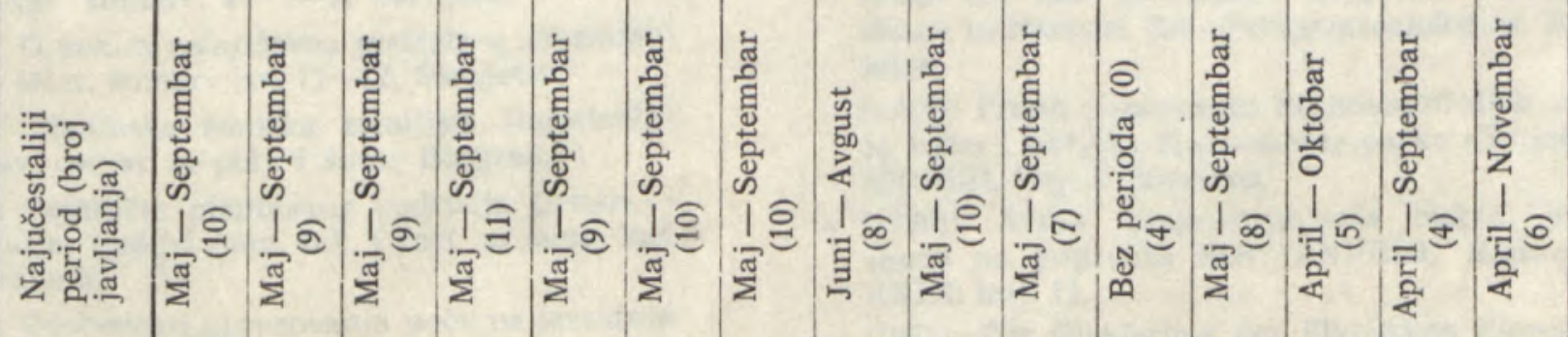

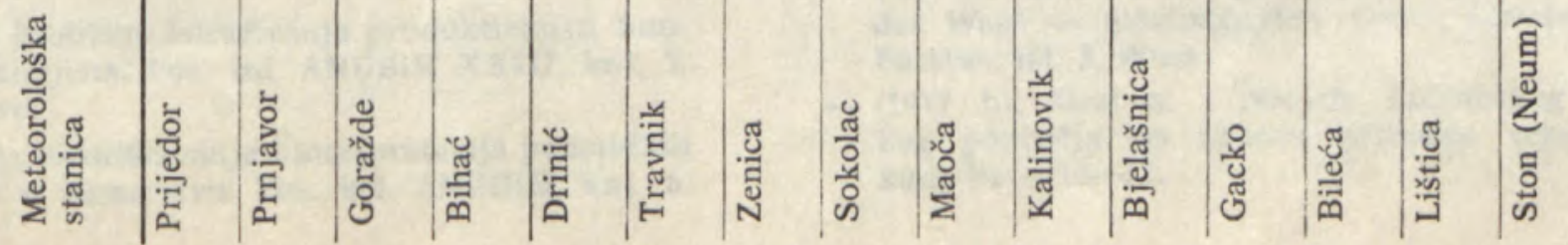


Ovo su također plitka, stjenovita, skeletna te suha zemljišta. Površinsku stjenovitost povećava linija površinskog kamenja zbog jake eolske erozije.

Realna šumska vegetacija: Najzastupljenije su fitocenoze medunca i bijelog graba (Querco pubescentis - Carpinetum orientalis $=$ Carpinetum orientalis) sa različitim geografskim varijantama, odnosno regresivnim stadijima $(C$. $O$. punicetosum, $C$. $O$. phylliretosum, C. O. petterietosum, C. O. paliuretosum, $C$. O. juniperetosum phoenicae, C. O. juniperetosum oxycedri), i drugim do prelaza u zajednice submediteranskih kamenjara iz sveze Satureion subspicatae.

Za ovaj rejon karakteristično je prisustvo brojnih zimzelenih elemenata, kao i fragmenata makije i gariga eumediteranskog područja (oko Trebinja, Popovog polja, Stoca, Svitave, Vitine itd.).

Manje enklave unutar ovog rejona, u povoljnim edafskim uslovima, zauzimaju šume sladuna $\mathrm{i}$ cera (Quercetum confertae adriaticum), te brojna nalazišta makedonskog hrasta.

Fragmentano su zastupljene manje enklave vrba i topola, poljskog jasena i lužnjaka na recentnim aluvijumima.

U najvišim predjelima raspoređene su disjunktno šume crnog graba (Querco - Ostryetum carpinifoliae).

Potencijalna šumska vegetacija: Podudara se sa realnom uz različite odnose zastupljenosti vegetacijskih jedinica.

\subsection{Eumediteransko područje}

Položaj: Zauzima primorski dio Hercegovine oko Neuma. Visinski se prostire od razine mora do $\mathbf{3 5 0}$ $\mathrm{m}$ nadmorske visine.

Klima: Za karakterisanje klime ovog područja poslužile su meteorološke stanice Neuma i Stona. Klima ovdje ima mediteranska obilježja, što proizlazi iz režima padavina i temperatura. Samo oko $30 \%$ godišnjih padavina je u vegetacionom periodu koji traje ovdje oko 270 dana, a bezmrazni period skoro čitavu godinu (tabela 6).

Odnos prihoda i rashoda vode je vrlo nepovoljan i prema mjesečnim podacima iznosi 0,41 .

Geomorfologija i geološka građa: Priobalno područje je karakterisano Neum - Klek zalivom i poluostrvom. Ima karakter karsne zaravni izgrađene od krečnjaka.

$\mathrm{Z}$ em $1 \mathrm{j}$ išta: Ovo područje je izgrađeno iz mozaika kalkomelanosola - terra rosse na krečnjaku.

Realna šumska vegetacija: Predstavljena je degradacionim stadijima šume česmine (Orno - Qurcetum ilicis) makijom i garizima.

Potencijalna šumska vegetacija: Područje pripada klimazonalnoj zajednici šume česmine. 


\section{I T E R A T URA}

A d a movi ć, L. (1907): Pflanzengeographische Stellung und Gliederung der Balkanhalbinsel. - Wien.

- (1909): Die Vegetationsverhältnisse der Balkanländer. Die Veget. der Erde, XI Leipzig.

B e c k, G. (1901): Die Vegetationsvethältnisse der illyrischer Länder. Die Vegetation der Erde, IV, Leipzig.

B e us, V. (1980): Zajednica bukovo jelove šume na peridotitu i serpentinitu Bosne, Magistarski rad. Radovi Sum. fak. i Instituta za šumarstvo u Sarajevu, Godina XXIV, Knj. 24., Sv. 6.

B u n u š e va c, T. (1959): Klimatski uslovi sjeveroistočne Srbije i pojava sušenja stabala u njenim bukovim šumama. Glasnik Šum. fak. br. 17, Beograd.

B u rli c a, č. (1971): Problemi proučavanja vodnog režima šumskih zemljišta. Radovi ANU BiH, Posebno izdanje, knj. 5, Sarajevo.

- (1980): Vodni režim najvažnijih tipova šumskih zemljišta (dokt. disertacija). Radovi Sum fak. knj. 23 , sv. $1-2$.

- (1979): Izdvajanje pedoloških jedinica i njihovo pedološko definisanje. Glasnik sum. fak., br. 4. Pos. izdanje, Beograd.

Burlic a, č. et al. (1971): Padavine u području Trebinja i njihov uticaj na debljinski prirast alepskog i crnog bora. Pos. izd. ANUBiH, XXIII, knj. 5, Sarajevo.

- (1977): Značaj poznavanja ekološko proizvodnog potencijala šuma submediteranskog područja Hercegovine u zaštiti čovjekove sredine. „Šum. liste, br. 10-12, Zagreb.

Burlica, C., Fabijanić, B. (1968): Ein Beitrag zur Landschafts-ökologischen Gliederung Bosniens und der Herzegovina auf pflanzensoziologisch-bodenkundlichen Grundlagen. „Pflanzensoziologie und Landschaftsökologie«. Bericht über das Int. Simp. Stolzenau/Weser 1963.

,C e s t a r, D. et al. (1970): Tipološko istraživanje i kartiranje šumskih staništa SR Hrvatske. Pos. izd. Inst. za šumarska istraživanja Hrvatske, Zagreb.

ćirić, M. (1962): Ein Beitrag zur Bodenbildung auf Serpentin. Zeitschrift für Pflanz. Düng. Bod. 96-141 / Band, Heft 2.

- (1958): Neki važniji problemi šumarske pedologije. "Nar. šumar", sv. 7-9, Sarajevo.

- (1959): O nekim nalazištima podzola u centralnoj Bosni. „Nar. šumar«, sv. 11-12, Sarajevo.

- (1961): Planinska šumska zemljišta Jugoslavije. Jug. sav. centar za polj. i šum., Beograd.

- (1966): Zemljišta planinskog područja Igman Bjelašnica. Radovi Sum. fak, i Inst. za šum., knj. 10, Sarajevo.

- (1967): Osobenosti obrazovanja počv na izvestnjekah i osnovi ih klasifikaii, Počvovedenie. No 1.

- (1975): Problemi istraživanja produktivnosti šumskih zemljišta. Pos. izd. ANUBiH XXIII, knj. 5, Sarajevo.

- (1975b): Iskorištavanje i interpretacija pedoloških karata u šumarstvu. Pos. izd. ANUBiH, knj. 6.
Cirić, M. Aleksandrović D. (1959): Jedno gledište o genezi terra rossa (crvenice). $\mathbf{Z b}$. rad. Polj. fak., br. 277, Beograd.

C i r i ć, M. et al. (1971): Uticaj stanišnih faktora na produktivnost bukovih šuma u BiH. Pos. izd. ANU $\mathrm{BiH}$ XXII, knj. 5.

- (1971b): Tipovi bukovih šuma i mješovitih šuma bukve, jele i smrče u Bosni i Hercegovini. Sum. fak. i Inst. za šum. Pos. izd. br. 8, Sarajevo.

- (1972): Proizvodni potencijal šumskih zemljišta BiH. Zemljište i biljka. Vol. 21, No 1. Beograd.

Đikić, S. (1965): Principi i perspektive unapređenja proizvodnje šumskog sjemena u Bosni i Hercegovini. Radovi Sum. fak. u Sarajevu, Posebno izdanje, Sarajevo.

F a bi j a n ić, B. et al. (1963): Pregled osnovnih tipova šumske vegetacije Lepenice. Naučno društvo SR BiH. Pos izd., knj. 3, Sarajevo.

- (1967): Tipovi šuma na eocenskom flišu severne Bosne. Radovi Sum. fak. i Inst. za šumarstvo u Sarajevu, knj. 12, sv. 1.

Filipovski, G. - ćirić, M. (1963): Zemljišta Jugoslavije, JDPZ. Pos. izd. 7, Beograd.

Fukarek, P. (1950): Današnje rasprostranjenje Pančićeve omorike (Picea omorica Pančić) i neki podaci o njenim sastojinama, Godišnjak Biološkog instituta, III, Sarajevo.

- (1951): Staništa Pančićeve omorike nakon šumskih požara u 1946-1947. godini, Sumarski list, $1-2$, Zagreb.

- (1955): Kartiranje šumske vegetacije i zadaci Zavoda za šumarsku botaniku Polj. šum. fak. u Sarajevu, „Nar. šumar«, br. 9-10, Sarajevo.

- (1955b): Zaštita endema Pančićeve omorike u Bosni i Hercegovini, Naše starine, sv. 3, Sarajevo.

- (1956): Nalazište alpske johe (Alnus viridis (Chair) D. C.) u Bosni, Nar. šumar, X, 9-12, Sarajevo.

- (1956 b): Zajednica klekovine bora (Pinetum mugi, Horv.) i neke njene razvojne tendencije na bosansko-hercegovačkim planinama. Sum. list, br. $11-12$.

- (1962): Inverzija vegetacije na planinskom masivu Igman - Bjelašnica. „Narodni šumar», sv. $1-2$, Sarajevo.

- (1966): Zajednica endemne munike na planini Prenju u Hercegovini, Acta botanica croatica, Vol. XXV, Zagreb.

- (1966 b): Das Quercetum confertae herzegovinicum in Narenta Tal. „Pflanzensoziologie«, Ht 19, Wien.

- (1969): Prilog poznavanju biljnosocioloških odnosa šuma i šibljaka Nacionalnog parka "Sutjeskaa, ANUBiH, knj. 3, Sarajevo.

- (1970): Areali rasprostranjenja bukve, jele i smrče na području BiH, ANUBiH, Radovi XXIX, knj. 11.

- (1977): Zur Gliederung der illyrischen Florenprovinz in natürliche Vegetationsgebiete mit Hilfe der Wald - gesellschaften. Centr. für des ges. Forstw., Ht. 3, Wien.

- (1977 b): Granice i podjela Jadranskog kraškog područja na osnovu prirodne vegetacije. Sum. list«. 10-12. 
- (1978): Fitocenološka istraživanja šumskih i šibljačkih zajednica na hercegovačkim planinama, Orjenu, Preju, Čvrsnici, ANUBiH, Radovi, knj. 11.

- $(1978$ b): Verbreitungsgebiete einiger Charakterarten der Slowenischen und Kroatischen Buchenwalder und ihre Bedeutung für die Regionale Gliederung des Dinarischen Florengebietes. Poroč. Vzhodnoal. - din. druž. preuč. veget. 14. Ljubljana.

- (1979): Die pflanzengeographische Abgrenzung des illyrischen vom moesischen Gebiet. "Phytocoenologia«, Ht. 6. Stuttgart.

- et Stefanović, (1958): Prašuma Peručica i njena vegetacija. Radovi Polj. šum. fak., br. 3, Sarajevo.

- et al. (1967): Zajednica bukve i javora gluhača (Aceri obtusati - Fagetum Fab., Fuk, Stef.) zapadnih dinarskih planina. Mitt. d. ostalp. - din. Arbeit gem., Ht. 7.

H orvat, I. (1954): Pflanzegeographische Gliederung Südosteuropas, Vegetatio 5-6, Der Haag.

- et al. (1974): Vegetatio Südosteuropas. Geobotanica selecta, Bd. IV, Stuttgart.

Horvatić, S. (1957): Biljnogeografski položaj Jadranskog Primorja i raščlanjenje krša. Monografija "Krš Jugoslavije«, Split.

- (1967): Fitogeografske značajke i raščlanjenje Jugoslavije. Anali flore Jugoslavije, br. 1. Zagreb.

J e le m, H. (1960): Grundzüge und Aufweisungen für die forstliche Standortserkundung und Kartirung. Forst. Bundesversuchsanstallt. Mariabrun, Ht. 1, Wien.

J o va nč evi ć, M. (1965): Rasporostranjenje, varijabilitet i sistematika crnog cera (Quercus macedonica A. DC.) u Jugoslaviji, JAZU Zagreb.

Jovi ć, D., et al. (1979): Primjena tipologije u savremenom gospodarenju šumama Jugoslavije. Glasn. Sum. fak. Pos. izd., knj. 4, Beograd.

Jova nović, B. (1954): Fitocenoza Quercetum confertae-cerris kao biološki indikator. Gl. šum. fak., sv. 8 , Beograd.

- (1967): Neke šumske fitocenoze severozapadne Srbije, Inst. za šum, istraživanja. Zbornik radova, knji. 6, Beograd.

Krause, W., Ludwig W. (1957): Zur Kenntnis der Flora und Vegetation auf Serpentinstandorten des Balkans. 2 Pflanzengesellschaften und Standorten in Gostović-Gebiet (Bosnien), Flora 145.

Ku š a n, F. (1956): Sastav i raspored vegetacije na planini Kamešnici (1849 m), God. Biol. inst. u Sarajevu, God. IX, Fasc. 1-2.

La kušić, R., (1975): Prirodni sistem geobiocenoza na planinama Dinarida, God. Biološ. Instituta Univerziteta Sarajevo, vol XXVIII, Sarajevo.

Lučić, V. (1965): Prilog poznavanju klimatskih odnosa na Igmanu. Radovi Sum. Fak. i Inst. za šumar. knj. 10, sv. 2 Sarajevo.

M a ly, K. (1938, 1939): Ravna planina kod Pala. Glasnik Zemalj. muzeja br. 50 i 51 . Sarajevo.

M a n uš eva, L. (1975): Organska materija u tlima pod šumskom vegetacijom, Posebna izdanja ANUBiH XXIII, knj. 5 Sarajevo.

- (1967): Sastav humusa u seriji tala na krečnjaku, Zemljište i biljka, vol. XVI, No 2, Beograd.
- (1970): Različja v nekotorih svojstvah gumusova gorizonta pod vlijanijem materinskoj parodi i sastava lesnih fitocenozov. Počvovedenie. No 6 . Moskva.

- et Cirić, M., (1969): O specifičnostima humusa u prašumskim zemljištima $\mathrm{BiH}$. Zemljište i biljka vol. 18, No 1-3 Beograd.

- (1971): Zemljišta na andezitu, andezito - dacitu i dacitu istočne Bosne, Arhiv za polj. nauke sv. 84 , god. XXIV. Beograd.

M a tić, V., et al. (1963): Metod Inventure šuma na velikim površinama I i II, Instit. za šumar. Sarajevo.

— et al. (1971): Stanje šuma u SR BiH prema Inventuri šuma na velikim površinama u $1964-1968$ godini. Posebna izdanja Sumar. fak. i Institut za šum. br. 7, Sarajevo.

M a yer, H., et al. (1971): Die Waldgebiete und Waldsbezirke Österreich. - Centralblatt für das gesamte Forstwesen, Heft 3. Wien.

Milosav l jević, R., (1976): Klima Bosne i Hercegovine, doktorska disertacija, (Mnsc.) Sarajevo.

- (1977): Opšta klasifikacija tipova klime u Bosni i Hercegovini. Seminar o korišćenju pedoloških i tipoloških karata u šumarstvu, (Mnsc.) Sarajevo.

- (1977): Suša i njen prostorni raspored u Bosni i Hercegovini Geografski pregled XXI, Sarajevo.

Moscheles, J., (1918): Das Klima von Bosnien und Herzegovina, Sarajevo.

O t to, H. J., (1972): Die Ergebnisse der Standortskartierung im Pleistozänen Flachland Niedersachsens - Grundlage Waldbaulicher Leitvorstellungen, (Doktorarbeit), Forstliche Fakul. Göttingen.

O b e r d o rf e r, E., (1948): Gliederung und Umgrenzung der Mittelmeervegetation auf d. Balkanhalbinsel. ber. Geobot. Forsch. Instit. Rübel in Zürrch.

Obuljen, A., (1954): Klimatska reonizacija i problemi našeg šumarstva, VIII. Sumarstvo, (1955) Beograd.

P in t a ri ć, K., (1957): Studie zum Lärcheanbau in Bosnien, Radovi Polj.-Sumar. fakul. Sarajevo.

P o pović, B., (1963): Neki rezultati ogleda sa đubrenjem crnoga bora, Agrohemija 7/8, Beograd.

- (1964) Tipovi tala na verfenskim pješčarima i glincima istočne $i$ jugoistočne Bosne, Radovi Šum. fak. i Inst. za šum. God. IX, knj. 9, sv. 3 Sarajevo.

- (1953): Tla nekih šumskih rasadnika sa gledišta primjene kalcifikacije, kao meliorativne mjere, Narodni šumar, 9/10, Sarajevo.

R a dkov, I. (1963): Gorski formacii i tipovete goru v NR Bulgaria, Zemizdat, Sofia.

Ritter-Studnička, H. (1956, 1957, 1959): Flora i vegetacija na dolomitima Bosne i Hercegovine: I. Konjic, God. Biol. Instituta, Sarajevo 1956, II. Dalja okolina Konjica i III. Kompleksi kod Drvara, na Boru i Ormanju kod Pazarića. God. Biol. Instit. Sarajevo, IV. Lastva kod Trebinja, God. Biol. Inst. 1959 Sarajevo.

- (1963): Biljni pokrivač na serpentinu u Bosni. God. Biol. instit. u Sarajevu sv. $1-2$, Sarajevo.

- (1970): Die Vegetation der Serpentinvorkommen in Bosnien, Vegetatio 21.

R ubner, K., R e in ha ld, K., (1953): Das natürliches Waldbild Europas. 
S t e f a n o vić, V., (1960): Tipovi šuma bijelog bora na području krečnjaka istočne Bosne. Naučno društvo NR BiH, knj. 4 Sarajevo.

- (1961): Prilog poznavanju mikroklime nekih šumskih staništa u području istočne Bosne. Radovi sum. fak. i Inst. za šum. God. VI, br. 6, Sarajevo.

- (1963): Sumska vegetacija šireg područja Trebevića, Naučno društvo SR BiH, Radovi XXV, knj. 7, Sarajevo.

- (1964): Sumska vegetacija na verfenskim pješčarima $\mathrm{i}$ glincima istočne $\mathrm{i}$ jugoistočne Bosne. Radovi Šum. fak. i Inst. za šum. knj. 9, sv. 3, Sarajevo.

- (1968): Fitocenoza cera (Orno - Quercetum cerris Ass. n.) i njeno biljnogeografsko mjesto $\mathrm{u}$ vegetaciji zapadne Bosne i šreg područja Dinarida. Glas. Zemalj. muzeja $\mathrm{BiH}$, sv. VII, Sarajevo.

- (1968): Fitocenoza brdskog lužnjaka u istočnoj Bosni (Quercetum roboris montanum, Stef. 1960), Ekologija, vol. 4, No 2, Beograd.

- (1970): Fitocenoza bijelog bora i smrče sa brdskim lužnjakom kod Knežine na Romaniji (As. Piceo - Pinetum quercetosum roboris, Stef.), Radovi ANUBiH, knj. 11, Sarajevo.

— et S o k a č, A., (1962): Fitocenoza bijelog bora i maljave breze na rubu tresetišta kod Han Krama (Pino - Betuletum pubescentis, Stef.), Radovi N. D. BiH, XIX, knj. 5, Sarajevo.

- et Manuševa, L., (1966): Sumska vegetacija i zemljišta na permokarbonskim pješčarima i škriljcima u Bosni, Radovi šum. fak. i Inst. za šum. knj. 11, sv. 3 Sarajevo.

- et Manuševa, L., (1971): Sumska vegetacija i zemljišta na andezitu i dacitu istočne Bosne, Radovi Sum. fak. i Inst. za šum., knj. 15, sv. 1-3, Sarajevo.

- et B e us, V., (1978): Die Phytozenosen der Zerreiche in den Vegetationsbedingungen Jugoslawiens, II. Inter. Simp. za floru i vegetaciju Balkana, Istanbul. (Mnscr.).

- et Beus, V., (1976): Zajednica zelene johe (Athyrio - Alnetum viridis Stef. et Beus) na Vranici planini u Bosni, Glasnik Zemalj. muzeja u Sarajevu (XIX - XX - 1980/81.

- (1977): Fitocenologija sa pregledom šumskih fitocenoza Jugoslavije, IGKRO „Svjetlost«, Univerzitetski udžbenik, Sarajevo
- et al. (1977a): Tipovi šuma hrasta kitnjaka u Bosni i Hercegovini, Radovi Šum. fak. i Inst. za šum. god., XX, knj. 20, sv. 1-2, Sarajevo.

- (1977b): Tipovi šuma crnog i bijelog bora u Bosni i Hercegovini, Radovi Sum. fak. i Instit. za šum. god. XX, knj. 20, sv. 1-2, Sarajevo.

- et. al. (1977c): Tipovi niskih degradiranih šuma submediteranskog područja Hercegovine, Radovi Sum. fak. i Inst. za šum. Posebni radovi, sv. 11, Sarajevo.

T s chermak, L. (1950): Die Waldgebiete Österreich. In Waldbau auf pflanzensoziologisch-ökologischer Grundlage, Wien.

- (1961): Zur Karte der Wuchsgebiete des österreichischen Waldes. Beibl. z. Wuchsgebietskarte, Wien.

Schlenker, G. (1962): Forstliche Vegetationskunde in Rahmen der forstlichen Standortskunde, referent in Wien, (mnscr.).

Trina js tić, I., (1978): O uticaju fitogeograskih granica na stupanj antropogene degradacije klimazonalne vegetacije Jadranskog primorja Jugoslavije. Sum. list sv. 11-12, Zagreb.

- (1980): Selektivna fitogeografska analiza flore Jugoslavije, IV. Simp. biosist. Jugoslavije rezimei referata (36), Đerdap.

V e mi ć, M., (1954): O klimi Bosne i Hercegovine, III. Kongres geografa Jugoslavije, Sarajevo.

Vla h in ić, M., (1969): Viškovi i manjkovi vode i njihova učestalost u području Sarajeva, Vodoprivreda No 1 .

V u k orep, I., (1965): Pedološka karta srednjebosanskog škriljavog gorja, M 1 : 100000, Sumar. fak. Sarajevo, (mnscr.).

- (1966): Sastav humusa kiselih zemljišta na filitu pod hrastom sa različitom prizemnom vegetacijom, (magistarski rad), Sarajevo, (mnscr.).

Witt ic h, W., (1963): Grundlage der forstlichen Standortskartierung und Grundzüge über Durchfürung, Forst. Fak. der Univer. Göttingen.

W r a b e r, M., (1960): Fitocenološka rasčlanitev gozne vegetacije v Sloveniji. Inštitut za biol. SAZU, Ljubljana. 


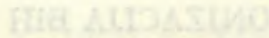




\author{
Dr Vitomir Stefanović \\ Mr Vladimir Beus \\ Dr Cedomir Burlica \\ Dr Hamza Dizdarević \\ Dr Ivan Vukorep
}

\title{
OKOLOGISCH - VEGETATIONSKUNDLICHE GLIE- DERUNG BOSNIENS UND DER HERZEGOWINA
}

Diese Studie stellt die erste Phase einer waldbau. lichen Gliederung Bosniens und der Herzegowina dar und wurde im Rahmen einer gemeinschaftlischen wissenschaftlichen Projektes vorgenommen. Sie beinhaltet Untersuchungsergebnisse der Bereiche Bodenkunde, Phytozenologie und Ókologie im weiteren Sinn, und sie besteht aus einem allgemeinen und besonderen Teil.

Der allgemeine Teil stellt eine Einführung dar, in der die theoretischen Grundlagen einer ökologischvegetationskundlichen Gliederung Bosniens und der Herzegowina sowie die Vorbedingungen ihrer Verwirklichung untersucht werden sowie das methodologische Verfahren mit einer Darstellung der Methoden bei der Bearbeitung der einzelnen Komponenten: Bodenkunde, Vegetation, Klima. In diesem Teil werden auch die Kriterien für eine Differenzierung des Bosnien und Herzegowine in homogene Einheiten von Gebiet, Bezirk und Region aufgezeigt.

Im besonderen Teil wird zuerst eine Tabellenübersicht der ökologisch-vegetationskundlichen Gliederung gegeben und im Ganzen dargestellt, um eine Deskription zu vermeiden.

Eine Analyse des gesamten Territoriums erlaubt die Verwendung der drei Kategorien Gebiet, B ezirk und Region.

Die Unterscheidungsmerkmale für Gebiet zur territorialen Gliederung sind: homogene phytogeographische klimatische Merkmale, relative Ǎhnlichkeit geomorphologischer und orographischer Gegebenheiten, Vorkommen einer oder mehrerer klimazonaler und klimaregionaler Phytozenosen sowie ihre besonderen Eigenschaften nach dem Vorkommen florischer Elemente, begonnen mit den weitesten bis zu den engsten synhorologischen Einheiten - Region, Provinz, Sektor.

Die andere Einheit Bezirk schliesst sich an das Gebiet nach den folgenden übernommenen Kriterien an: wenn er besondere gemeinsame phytogeographische Charakteristiken aufweist sowie einige spezifische geomorphologische, orographische und klimatische Merkmale besitzt. In anbetracht der Waldvegetation ist er ebenfalls gekennzeichnet durch eine hervortretende Charakteristik einiger klimazonaler und klimaregionaler Waldgesellschaften, z. B. Buchen- und Tannenwälder mit Fichte und Buchen- und Tannenwälder ohne Fichte. Ausbreitung grösserer Waldkomplexe, bedingt durch orographischedaphische Faktoren (Föhren und Schwarzkiefer - wälder auf Dolomit, Serpentinit, Kal,kstein) orographisch - edaphische Bedingungen der Eichenwälder usw.
Innerhalb der erwähnten Gebiete (nicht alle) werden die Einheiten auch in R e g i o n e n hervorgehoben. Die Kriterien sind Besonderheiten eines Teils dieses Territoriums, besondere geomorphologische, orographisch-edaphische und Wegetationkundliche Eigenschaften.

Für jede Einheit, bzw. ökologisch-vegetations kundliche Kategorie wurden die grundlegenden ökologischvegetationskundlichen Daten bearbeitet. Die-höchste Kategorie Gebiet umfasst folgende Elemente: geographische Lage, Klima, Geomorphologie, Boden, phytogeographische Zugehörigkeit; $\mathrm{Bezirk}$ und Region umfassen die Elemente: geographische Lage, Klima, Geomorphologie, Boden, reale Waldvegetation, potentiale Waldvegetation.

Die Kategorien Gebiet und Bezirk sind klimatisch mit Angaben der zugehörenden metheorologischen Standorte in den Tabellenübersichten mit den Bezeichnungen gekennzeichnet: metheorologischer Standort, Höhe ï. M., Breitengrad nach Greenwich, Lufttemperatur, relative Feuchtigkeit, Niederschläge, N/S Quotient, Trockenheits-Index, Dauer der Vegetationsperiode, potentiale Evapotranspiration, Klima-Index Im. Ebenfalls sind die Wasserbilanzen für Gebiete und Bezirke graphisch dargestellt sowie Diagramme der Kontinentalität des Klimas.

Interpretationen des textlichen Teils der Studief stehen integral in Verbindung mit den kartographischen Beiträgen, die hier aus technischen Gründen im Masstab 1: 500.000 gedruckt wurden, obwohl ursprünglich alle Beiträge im Masstab 1: 200.000 hergestellt waren.

Die Studie enthält folgende kartographischen I Beiträge:

Karte der ökologisch-vegetationkundliche Gliederung Bosniens und der Herzegowina, M 1 : 500.000;

Bodenkundliche Karte Bosniens und der Herzego. wina, M $1: 500.000$;

Karte der realen Waldvegetation Bosniens und der Herzegowina, M 1: 500.000;

Karte der potentialen Waldvegetation Bosniens und der Herzegowina, M 1 : 500.000 ;

Karte potentialer Evapotranspiration in Vegetationsperioden, M 1 : 1.000 .000 ;

Karte der Dauer von Vegetation perioden bei Temperaturen höher als $10^{\circ} \mathrm{C}$ in Bosnien und der Herzegowina, M $1: 1.000 .000$. 
SUMARSKI FAKULTET U SARAJEVU

Posebna izdanja*

1. MATIC V., VUKMI- Tablice taksacionih elemeROVIC V., DRINIC nata visokih šuma jele, smrP., i STOJANOVIC če, bukve, bijelog bora, crO.: nog bora i hrasta kitnjaka na području Bosne, Sarajevo, 1963.

2. ĐIKIC S., KOLAKO- Osnovi za proizvodno ekoVIC R.:

lošku klasifikaciju zapuštenih i degradiranih panjača u Bosni i Hercegovini, Sarajevo, 1965.

3. ĐIKIC S., JOVANCEVIC M., PANOV A.:

Principi i perspektive unapređenja proizvodnje sjemena u Bosni i Hercegovini, Sarajevo, 1965.

4. MATIC V.:

O planiranjima i o snimanjima u okviru uređivanja šuma, Sarajevo, 1965.

5. KAPETANOVIC N.: Orijentacija samostalnog premjera, Sarajevo, 1966 .

6. TERZIC D.:

Proučavanje hemijskog sastava zelenila šumskog drveća - sirovine za proizvodnju koncentrata stočne hrane. Sarajevo, 1970.

7. MATIC V., DRINIC Stanje šuma u SR Bosni i P., STEFANOVIC V., Hercegovini prema inventuCIRIC M.:

ri šuma na velikim površinama u 1964-1968. godini. Sarajevo, 1971.

8. CIRIC M., STEFANOVIĆ V., DRINIC P.:

Tipovi bukovih šuma i mješovitih šuma bukve, jele i smrče u Bosni i Hercegovini, Sarajevo, 1971.

9. TERZIC D:

Proučavanje hemijskog sas
10. GEORGIJEVIC E. LUTERSEK D., GAVRILOVIC D., JARE BICA M.:

11. STEFANOVIC V., BURLICA Č., DIZDAREVIC H., FABIJANIC B., PROLIC N.

12. MATIĆ V.: V., PAVLIC J., PRO LIC N., STOJANOVIC O., VUKMIRO VIC V.:

14. STEFANOVIC V. MILANOVIC S., ME. ĐEDOVIC S., PINTA RIC K., RONCEVIC $\mathrm{S}$. i SISOJEVIC D.

15. MIHAC B. i JELICIC V.:

16. STEFANOVIC $\mathrm{V}$., BEUS V., BOZALO G., PAVLIČ J., VUKOREP I:

17. STEFANOVIC V., BEUS V.

BURLICA, C. DIZDAREVIC, $\mathrm{H}$. VUKOREP, I:

* Sumarski fakultet u Sarajevu izdaje redovnu periodičnu ediciju "Radovi« Sumarskog fakulteta. U toj ediciji objavljuju se naučni radovi nastavnika i saradnika Šumarskog fakulteta. Osim "Radova..." povremeno se publikuju i pPosebna izdanjaa u kojima se stampaju strucni radovi i rezultati naučnih istraživanja namijenjeni praksi. Do i rezultati naučnih istraživanja namijenjeni praksi. Do sada je, uključujući $i$ ovu knjigu publikovano $17 \mathrm{knjiga}$
„Posebnih izdanja๙. Naslovi tih knjiga $\mathrm{i}$ godine izdavanja navedeni su u ovom pregledu izdanja.
Prilog poznavanju entomofaune šuma Bosne i Hercegovine, Sarajevo, 1976.

Tipovi niskih degradiranih šuma submediteranskog područja Hercegovine, Sarajevo, 1977.

Metodika izrade šumskoprivrednih osnova za šume u društvenoj svojini na području SR BiH, Sarajevo, 1977.

Tablice taksacionih elemenata visokih i izdanačkih šuma u SR Bosni i Hercegovini, Sarajevo, 1980.

Ekotipovi bijelog bora (Pinus silvestris L.) u Bosni, Sarajevo, 1980.

Istraživanja sredstava i metoda pri utovaru $\mathrm{i}$ istovaru drveta. Sarajevo, 1980.

Tipovi šuma smrče i bijelog bora, jele i smrče i smrče u Bosni, Sarajevo, 1983.

Ekološko-vegetacijska rejonizacija Bosne i Hercegovine, Sarajevo, 1983. tava zelenila šumskog drveća - sirovine za proizvodnju koncentrata stočne hrane, Sarajevo, 1973. 


\section{UPUTSTVO SARADNICIMA}

Casopis "Radovi Sumarskog fakulteta u Sarajevu objavljuje rezultate istra živanja saradnika Fakulteta, a izuzetno $i$ drugih naučnih radnika $i$ stručnjaka. Izlazi kao redovna periodična edicija. Osim "Radova" povremeno se publikuju "Posebna izdanja" $u$ kojima se štampaju rezultati naučnih istraživanja namijenjeni praksi.

Rukopisi se predaju Komisiji za izdavačku djelatnost Sumarskog fakulteta putem Sekretarijata Fakulteta $i$ uz odluku organa upravljanja o obezbjeđenom finansiranju. Oni moraju biti posebno pripremljeni za štampu, što znači da su uredno otkucani na pisaćoj mašini $u$ dva primjerka $s$ proredom i s vidno izdvojenim naslovima poglavlja $i$ potpoglavlja na papiru formata A 4.

Svaki rukopis obavezno sadrži sljedeće dijelove: abstrakt, uvod $i$ problem istraživanja, primijenjeni metod, rezultate istraživanja s diskusijom, zaključke, rezime rada na jednom ili više svjetskih jezika, spisak korištene literature $i$ sadržaj rada.

Abstrakt sadrži sljedeće podatke: prezime $i$ početno slovo imena autora, godinu izdavanja (u zagradi), naziv rada, podatke o svesci, stranu (od-do) $i$ kratak sadržaj rada na stranom jeziku.

Latinski nazivi biljaka $i$ životinja podvlače se u rukopisu prilikom kucanja.

Eventualni grafički prilozi (crteži, grafikoni $i$ dr.) moraju biti izrađeni tušem na paus papiru formata prilagodenog odnosu dimenzija kucane strane ili odnosu njene polovine. Fotografije moraju biti jasne $i$ kontrastne, te vezane za tekst.

Imena autora pišu se verzalom ili kurentom sa proredom, $u$ originalu jezika, $s$ godinom izdanja rada $u$ zagradi. Ukoliko se citira rad koji ima više od dva autora, $u$ tekstu se pominje samo prvi autor, sa dodatkom wet al.«. Ako se navodi autor s više radova iz iste godine onda se, uz radove, dodaju abecedna slova pored godine.

$U$ sliteraturi« se radovi navode $u$ originalu jezika, bez numeracije, abecednim redom prezimena autora, $i$ to: prezime $i$ početno slovo imena, godina izdanja rada (u zagradi), naziv rada, časopis, broj toma i sveske, stranica (od-do), a kod knjiga još i mjesto izdavanja. Navode se imena svih autora korištenog rada.

Obim radova može iznositi najviše do četiri autorska tabaka 64 kucane stranice). Za magistarske radove i disertacije dozvoljava se obim do šest autorskih tabaka, odnosno do 100 kucanih stranica. Za radove koji ce biti objavljeni kao "Posebna izdanja obim, po pravilu, nije ograničen.

Pored navedenih tehničkih uslova, obavezno je priložiti $i$ dvije recenzije rada, a autor je dužan dati pismenu izjavu da rukopis nije predao niti će predati za štampanje na nekom drugom mjestu.

KOMISIJA ZA IZDAVACKU DJELATNOST 


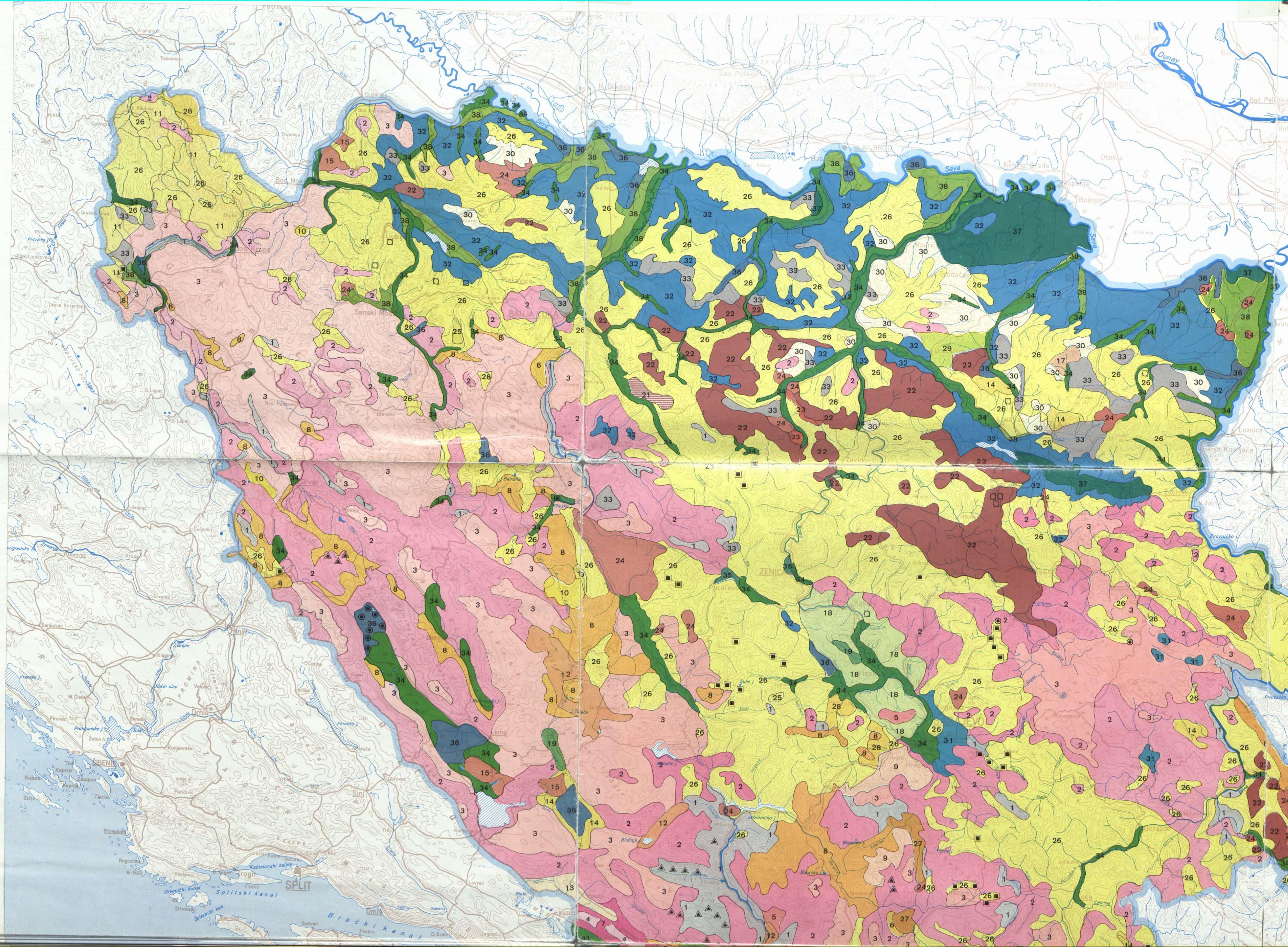




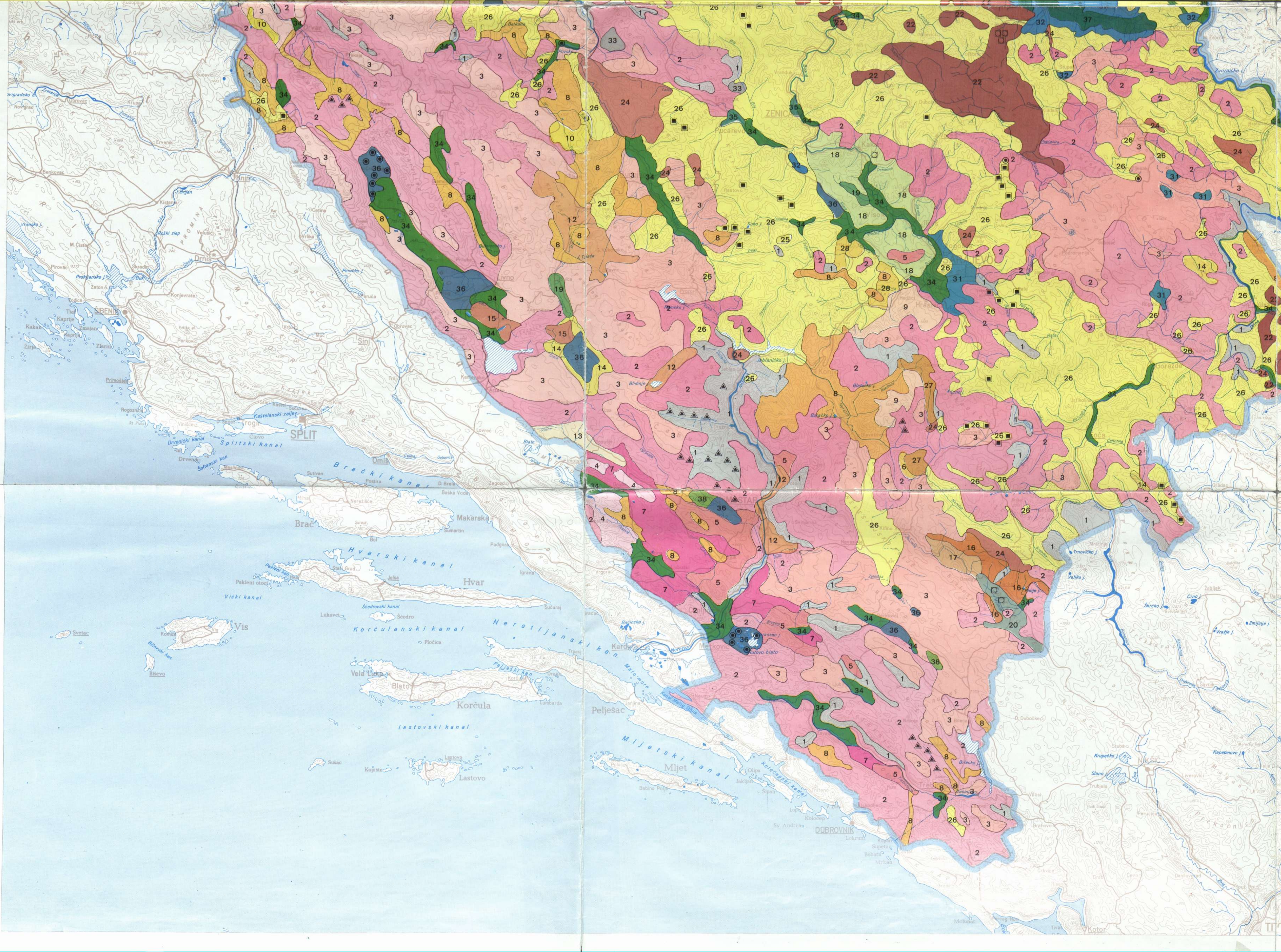




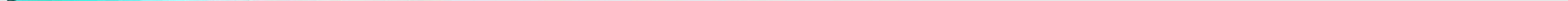




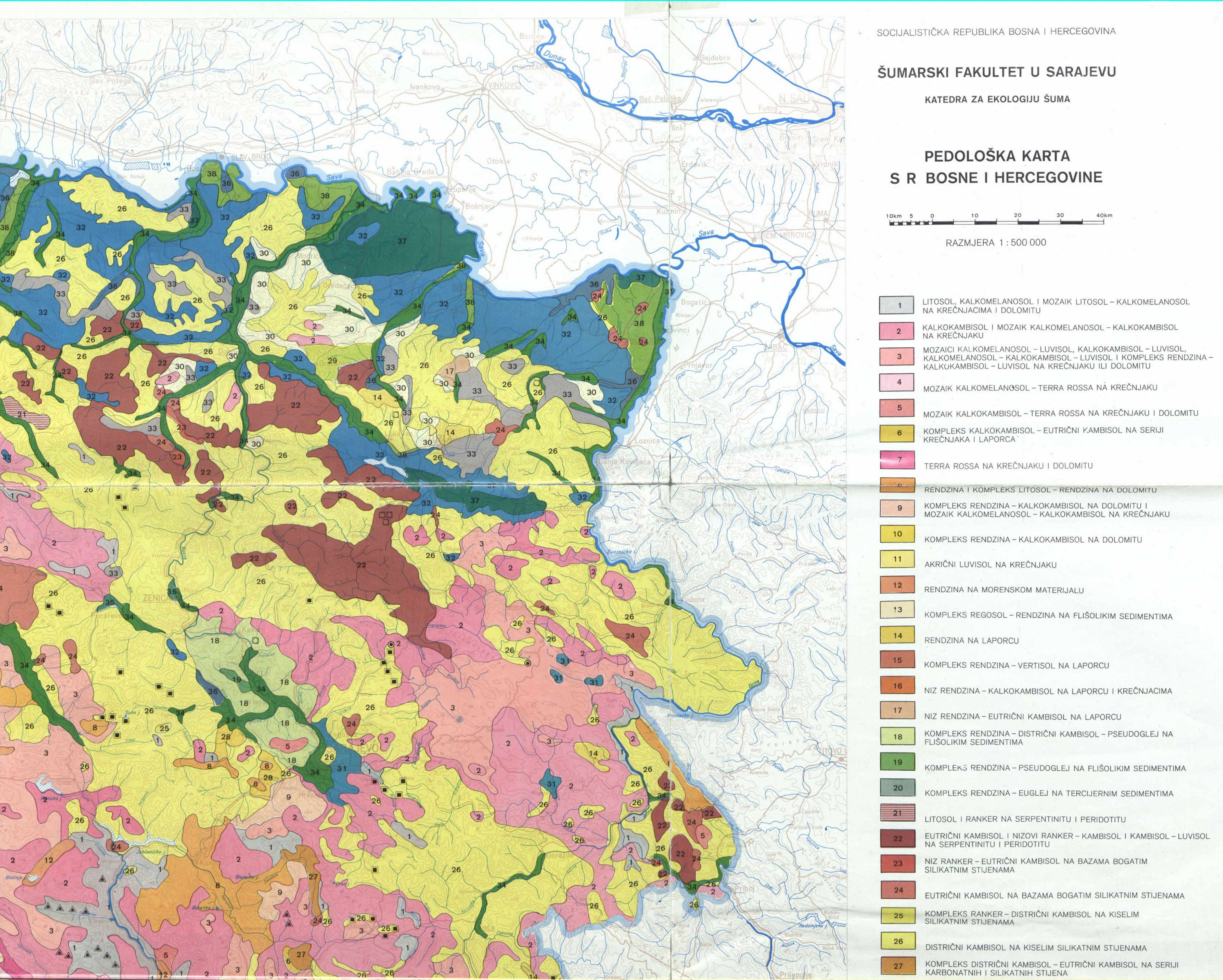



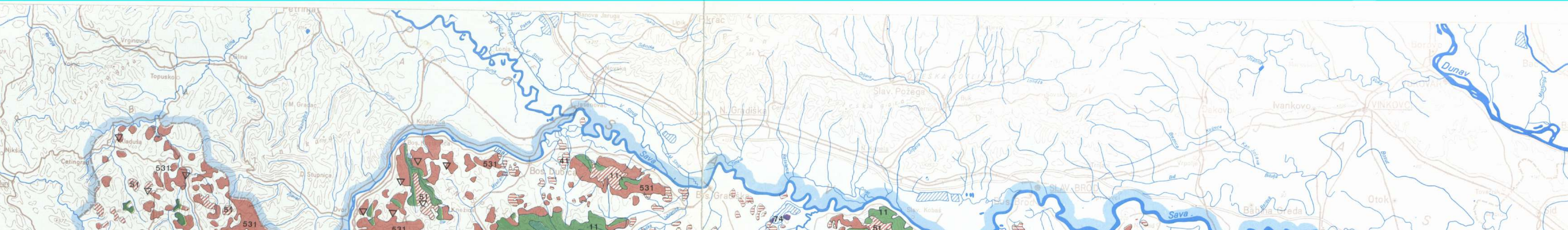

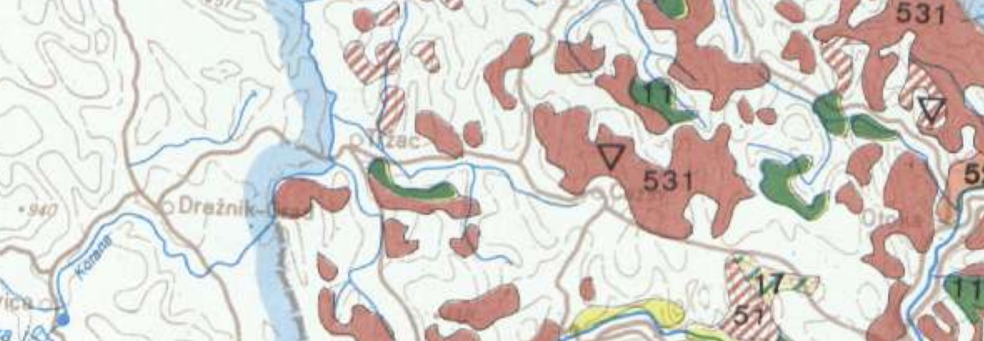

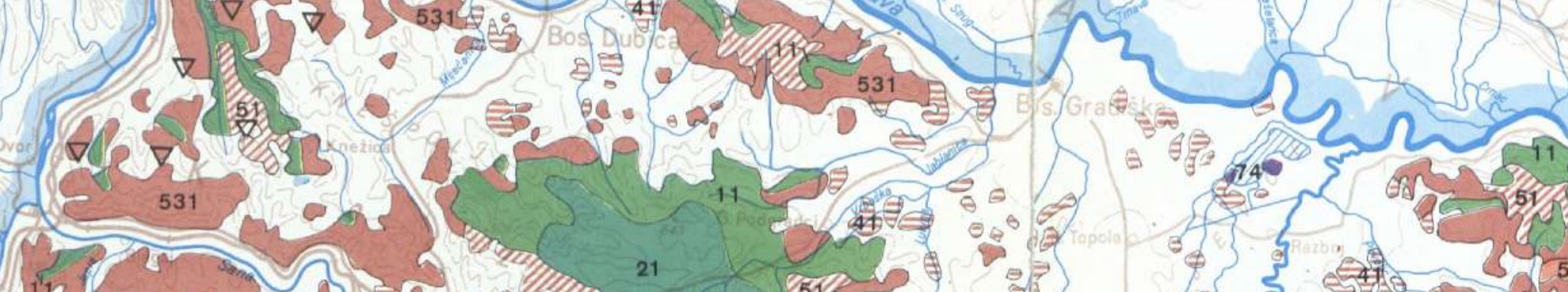

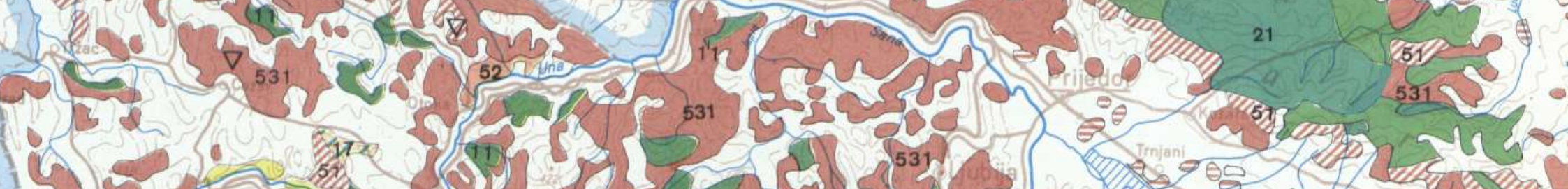

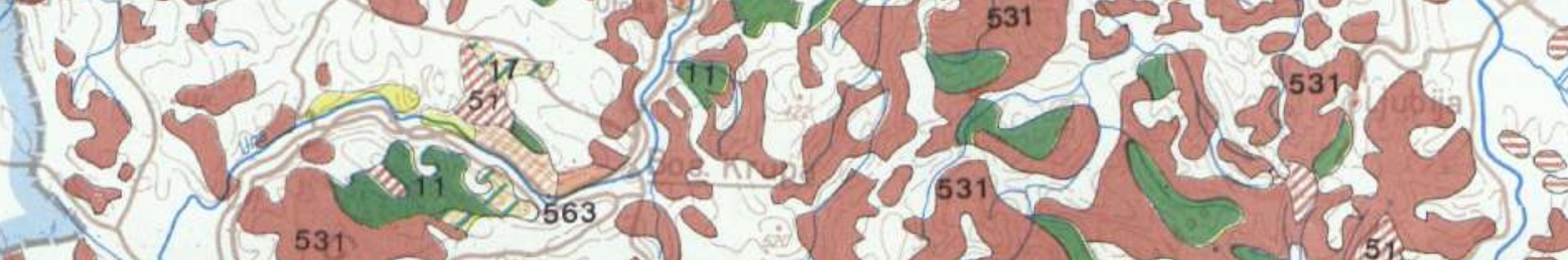

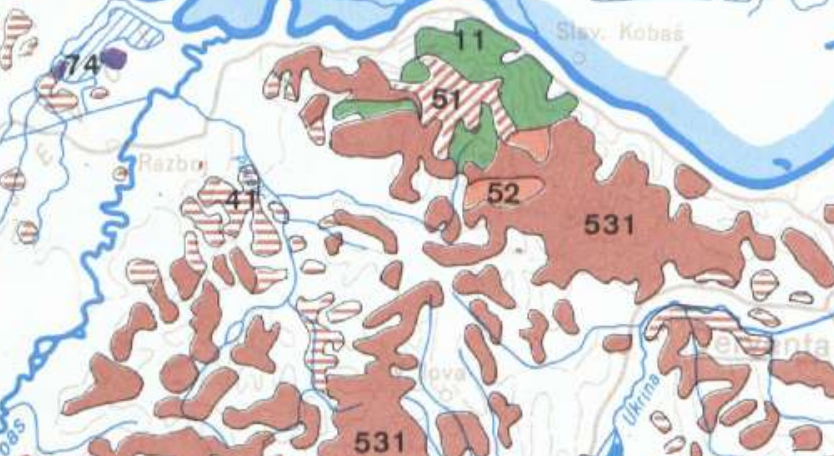

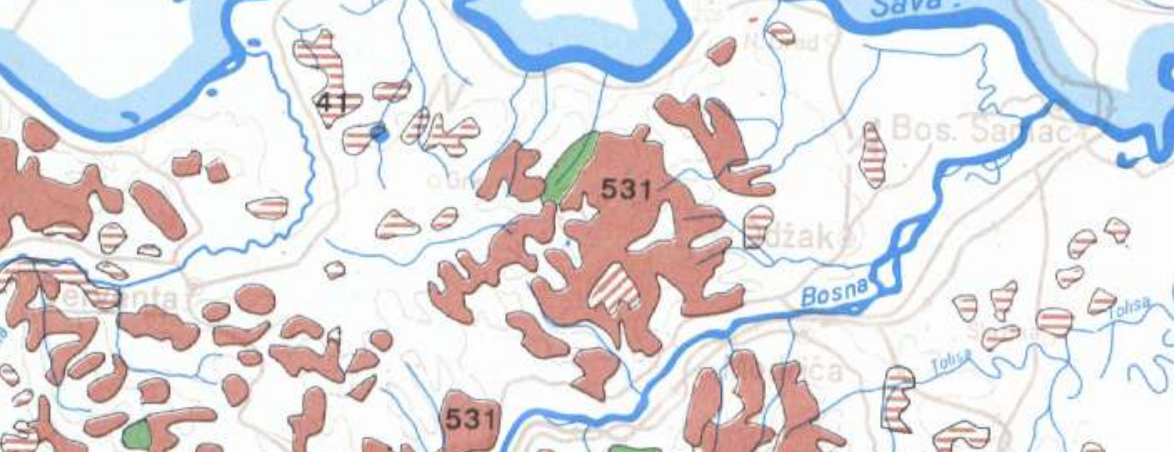

1. 1 .

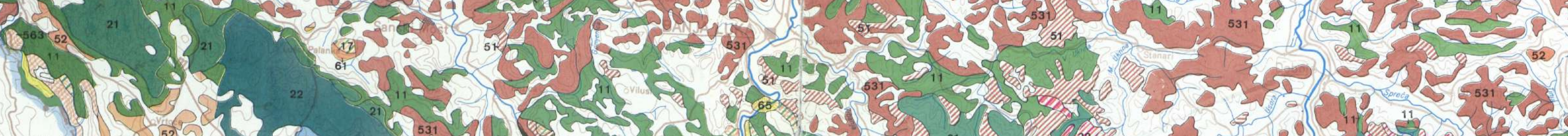
Hol

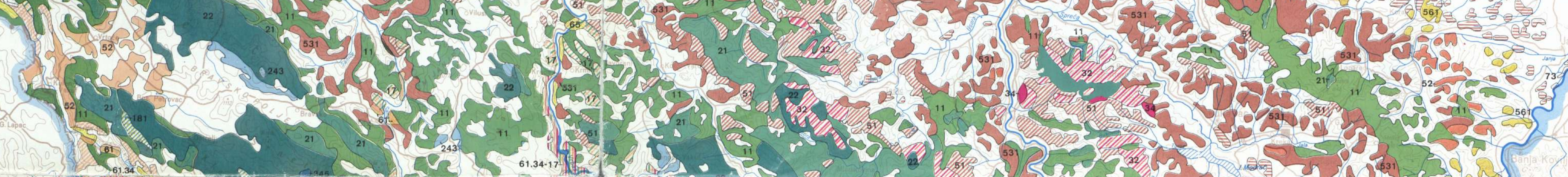

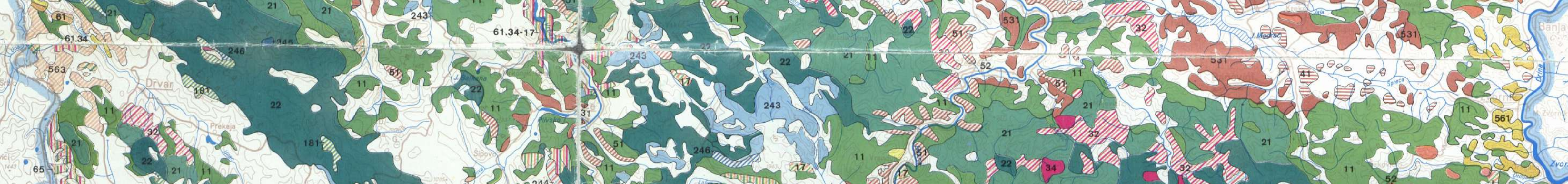

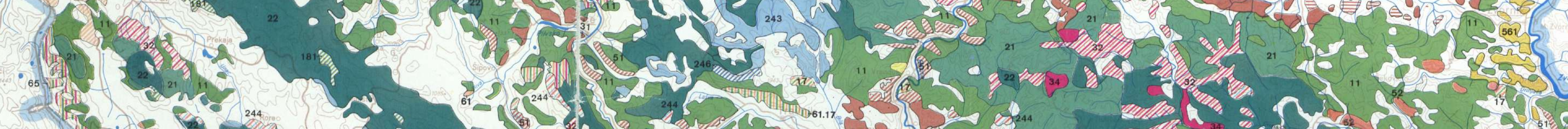
5 f

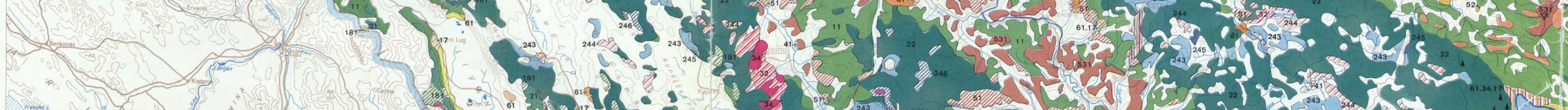
(1) (3) (1)

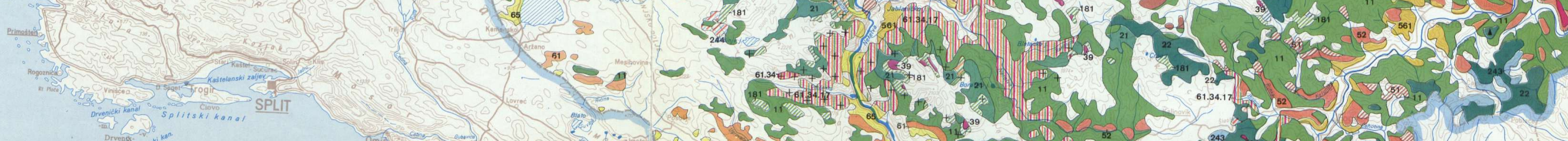

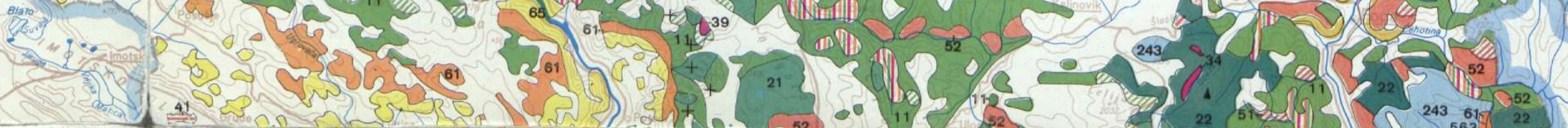




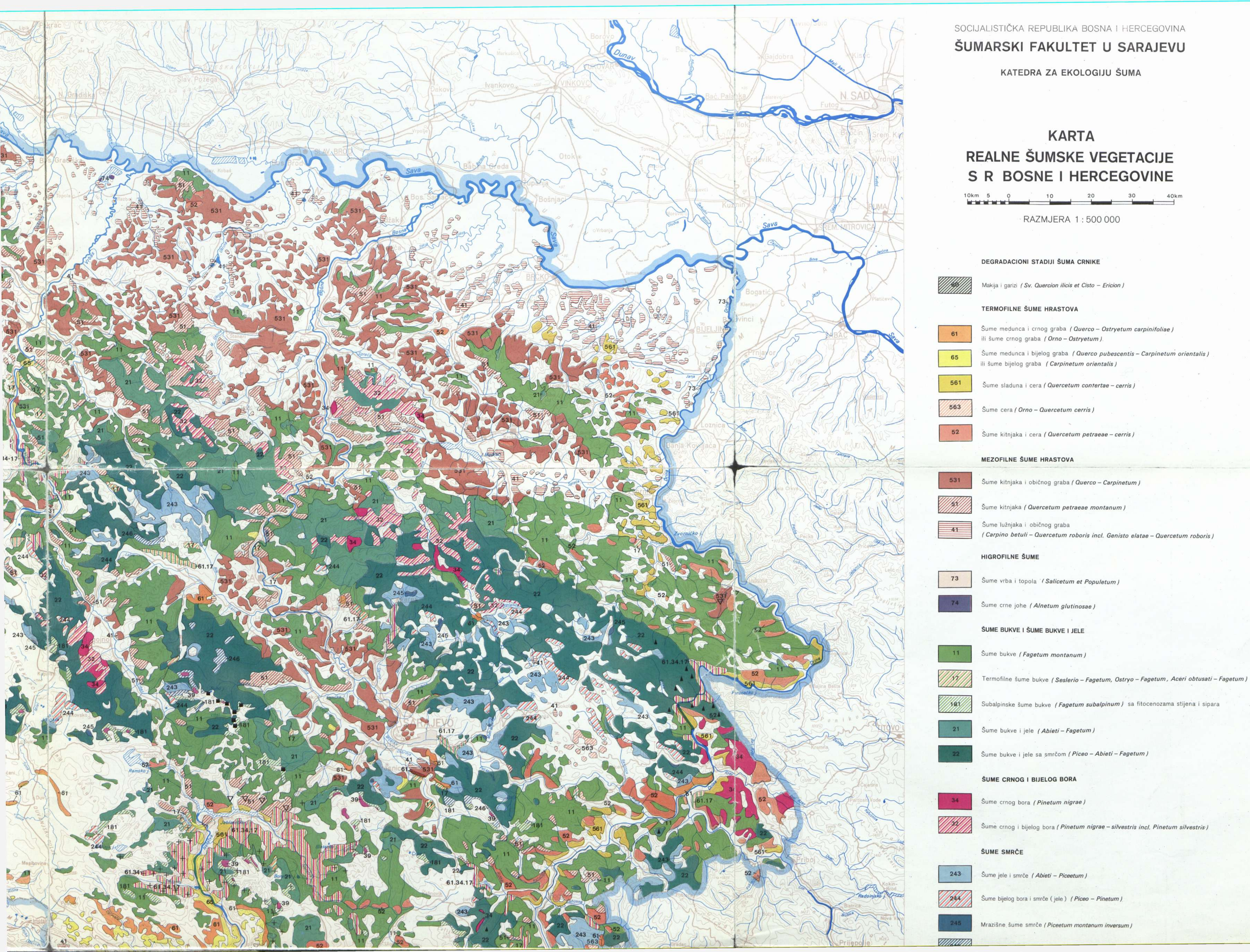




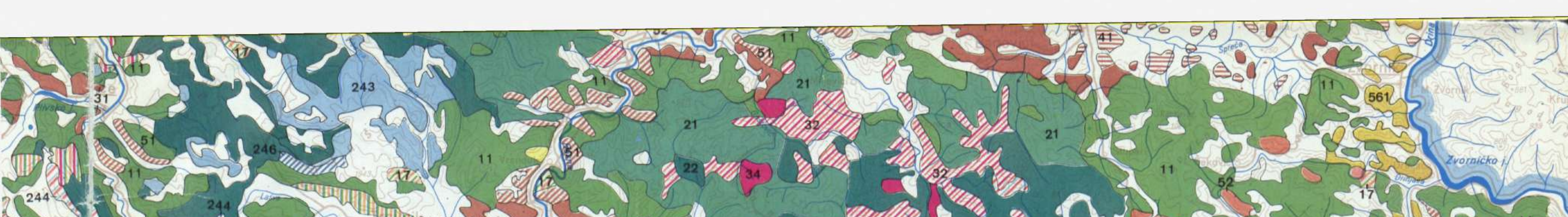

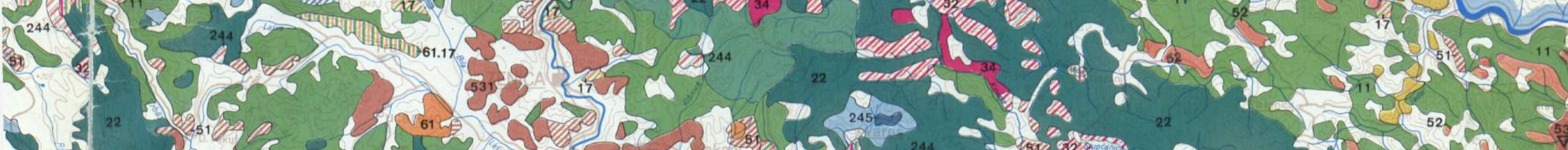
1.1.2. If

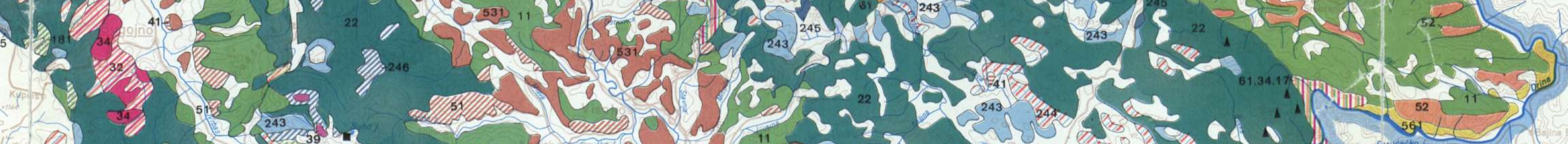

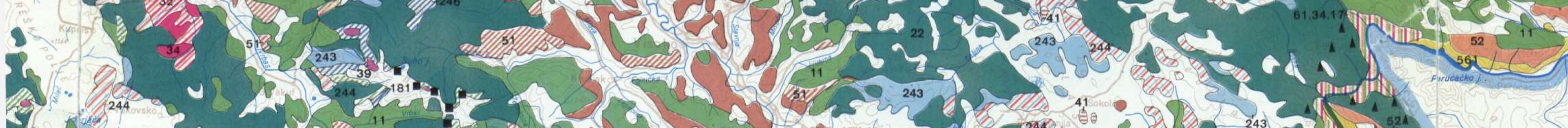

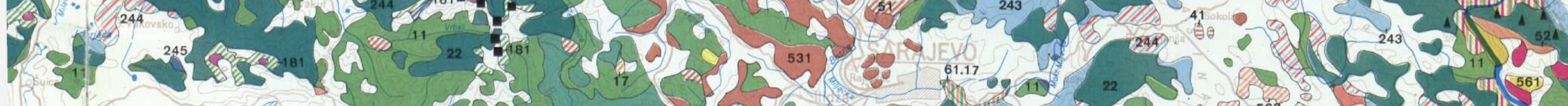

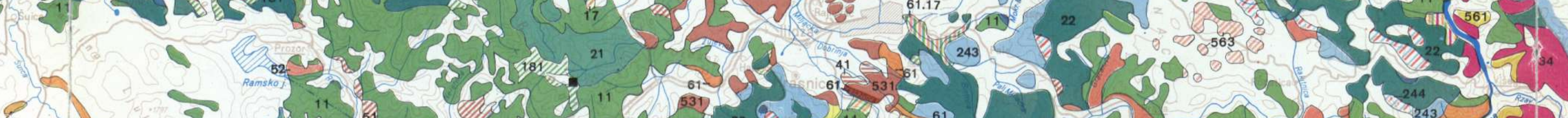
2. - - a

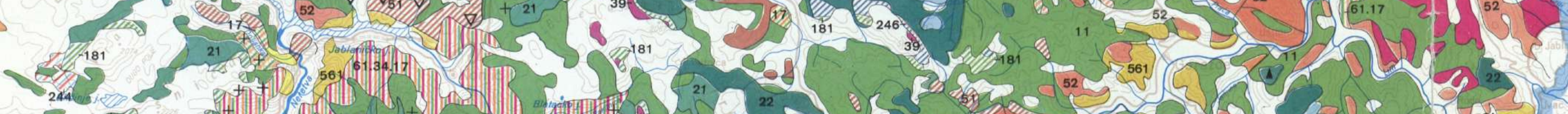

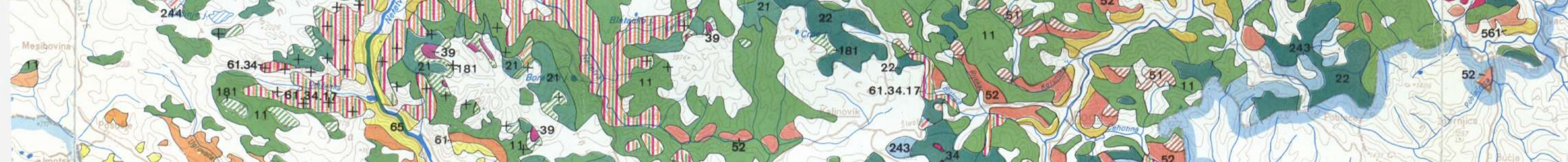
$3 \times$ t.

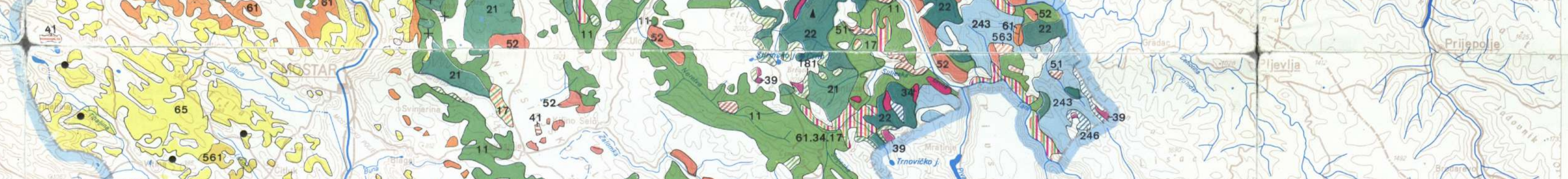
$34)^{2}$

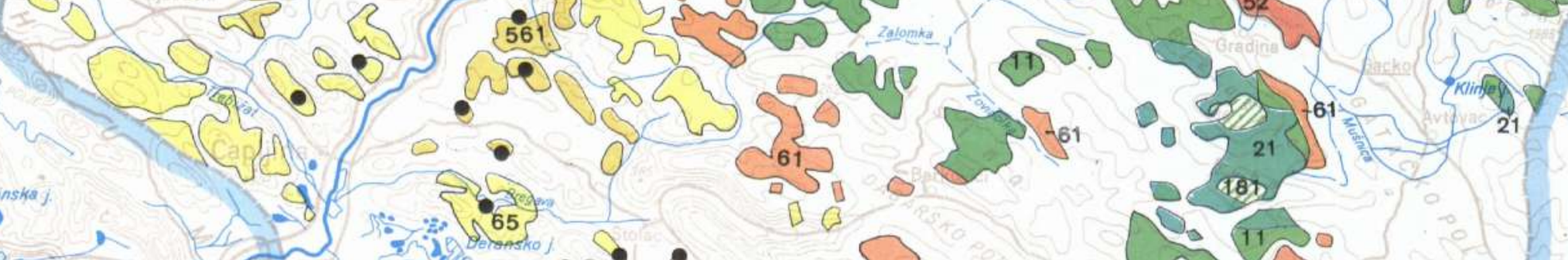
Earistain (a)
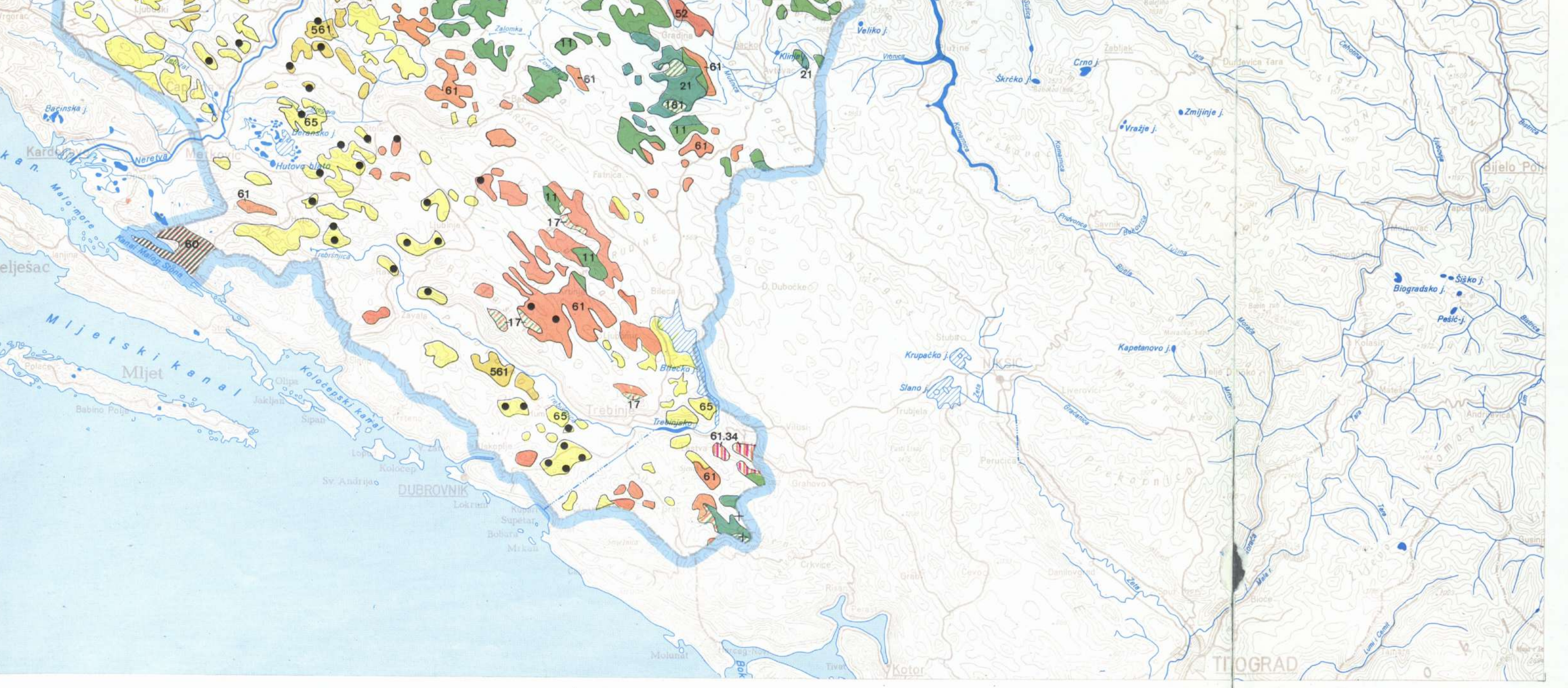

|테페

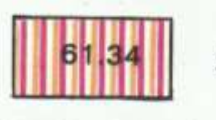

|billat:

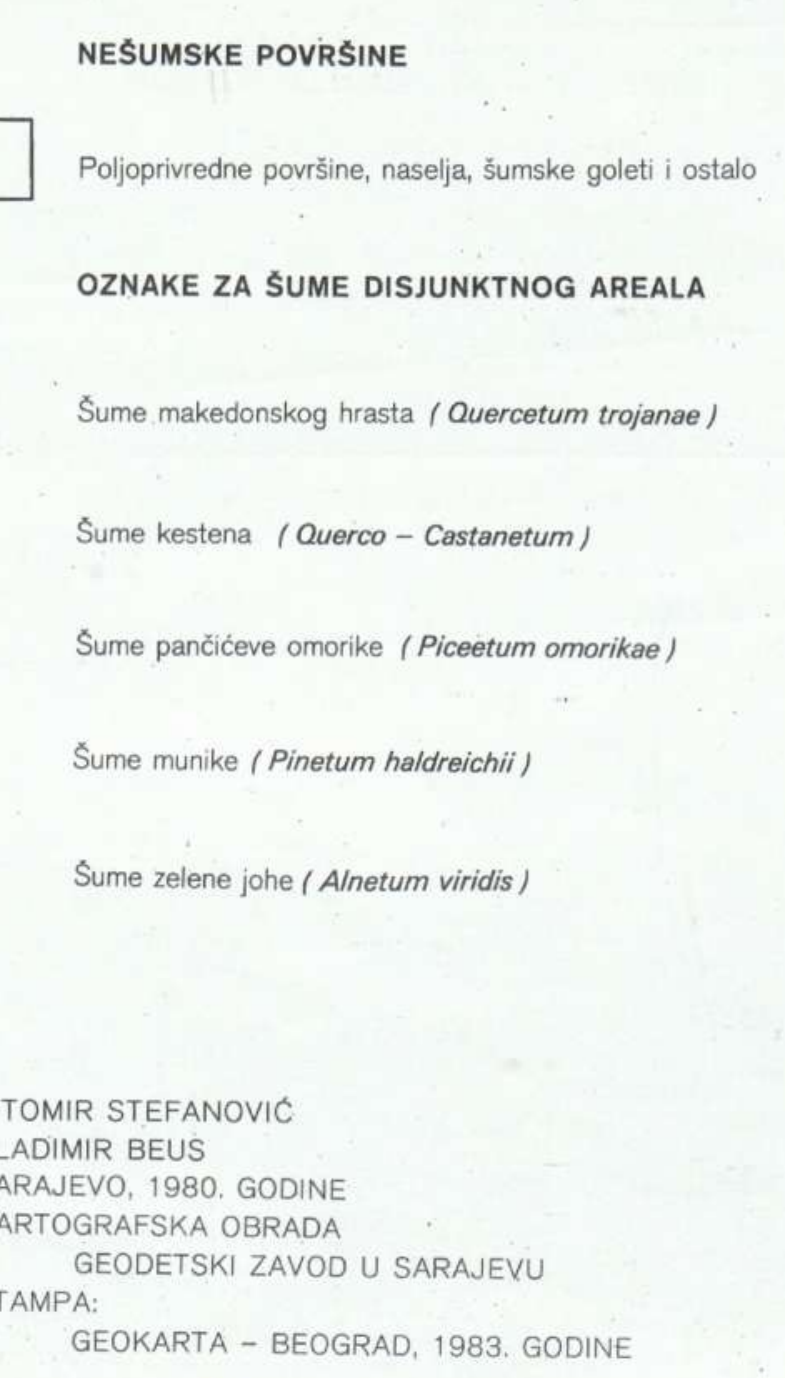




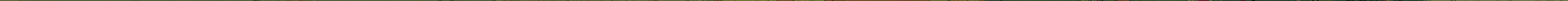





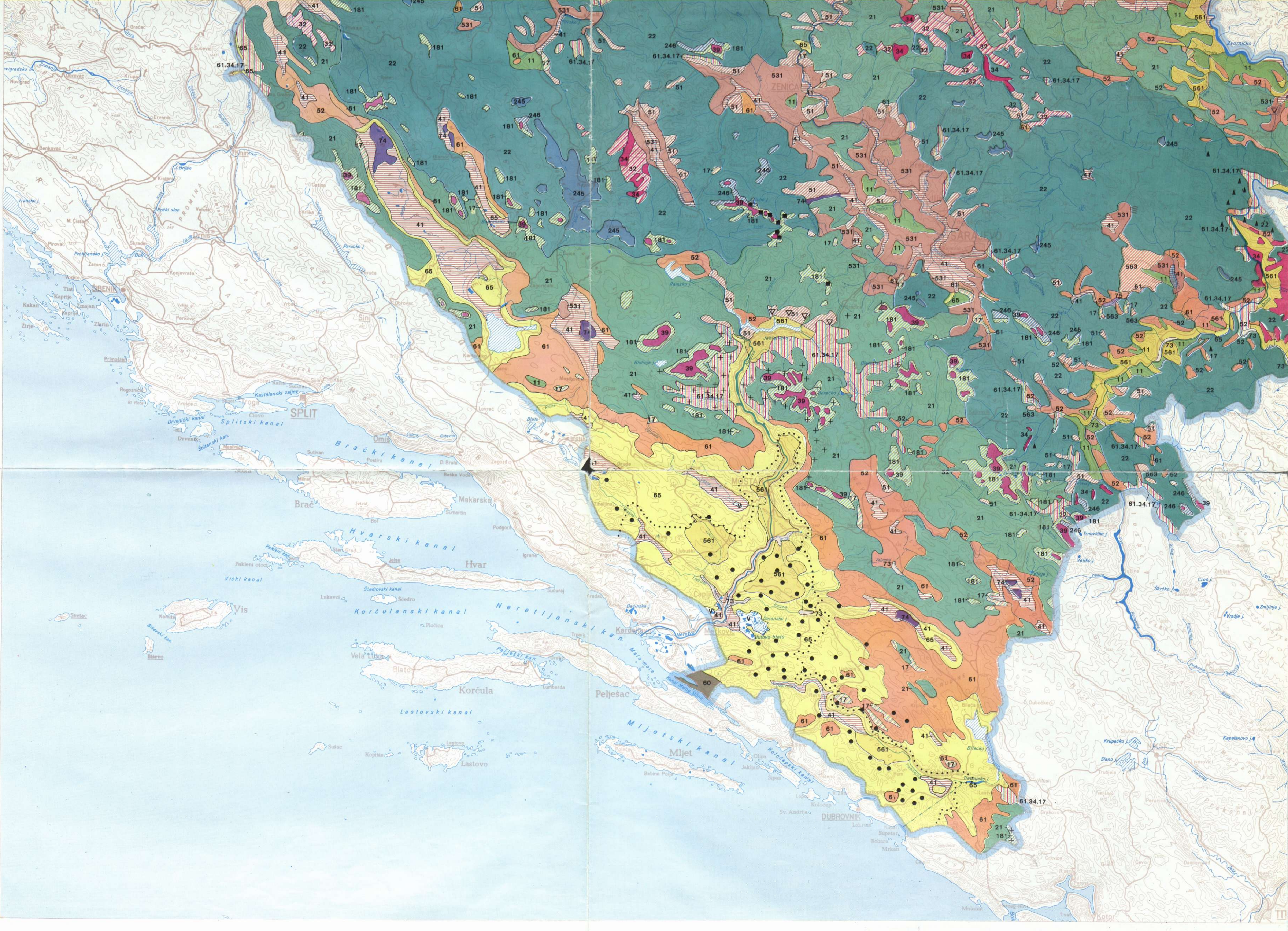




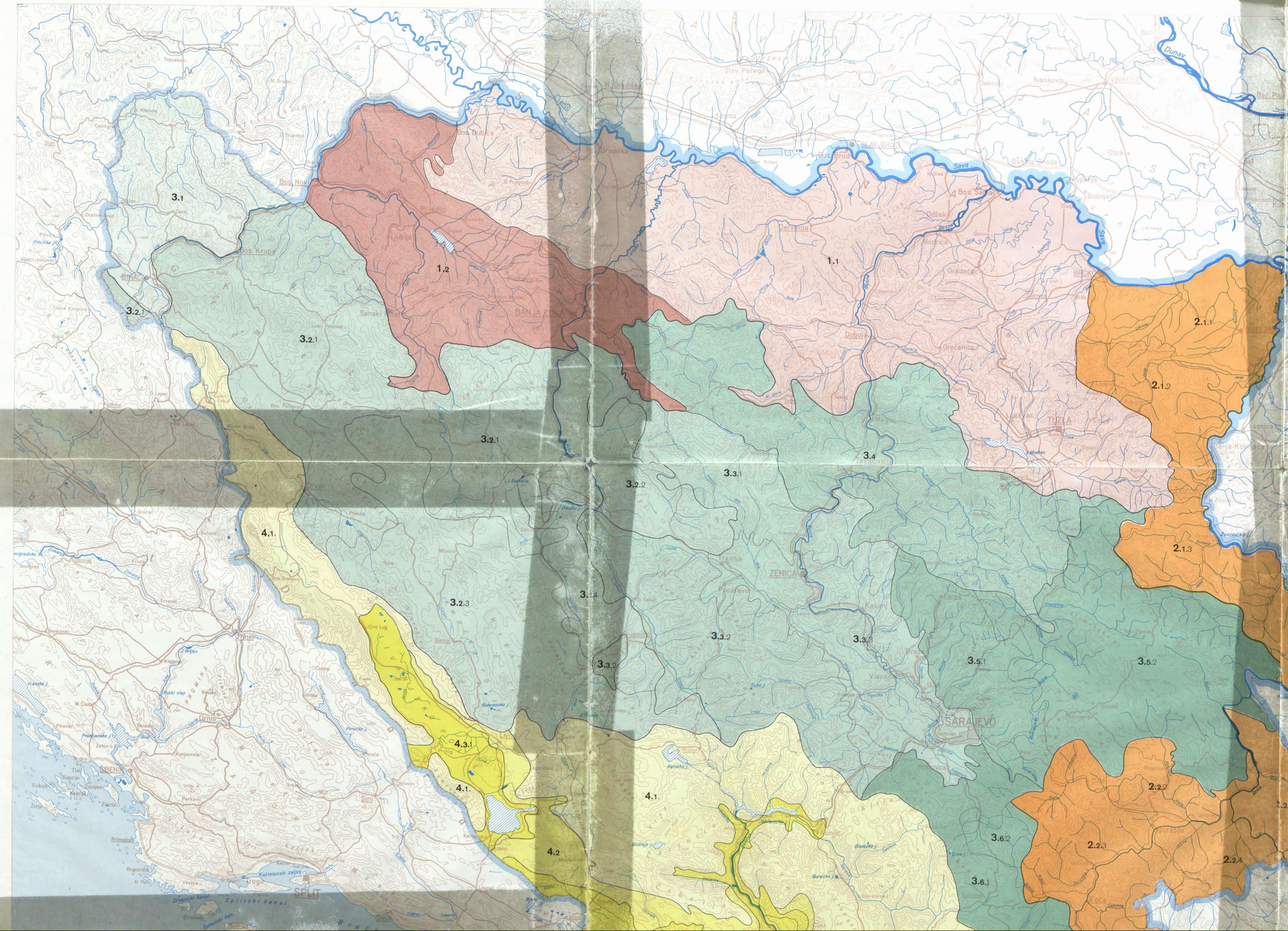




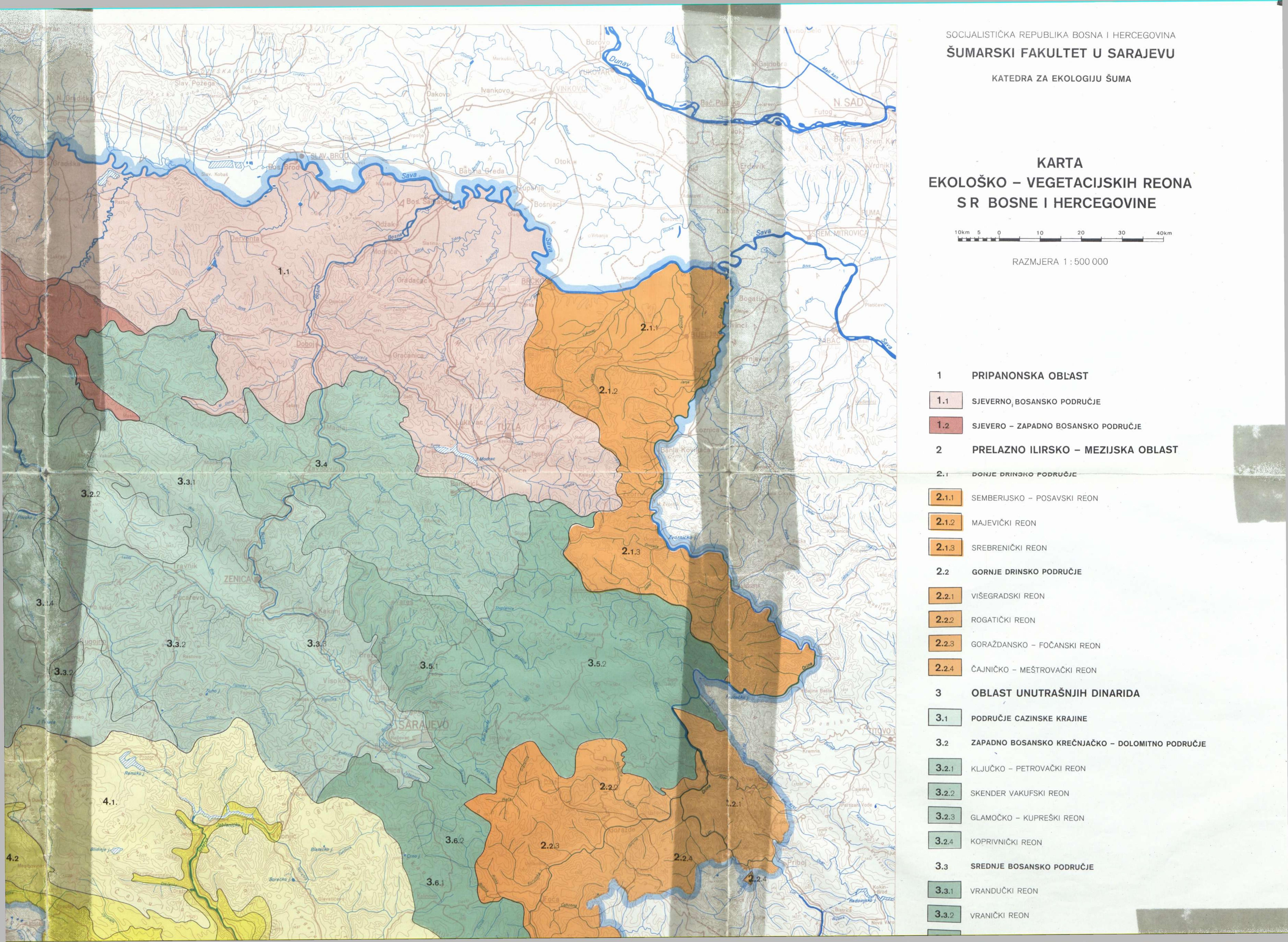




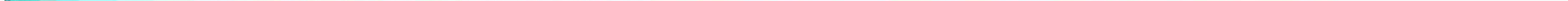




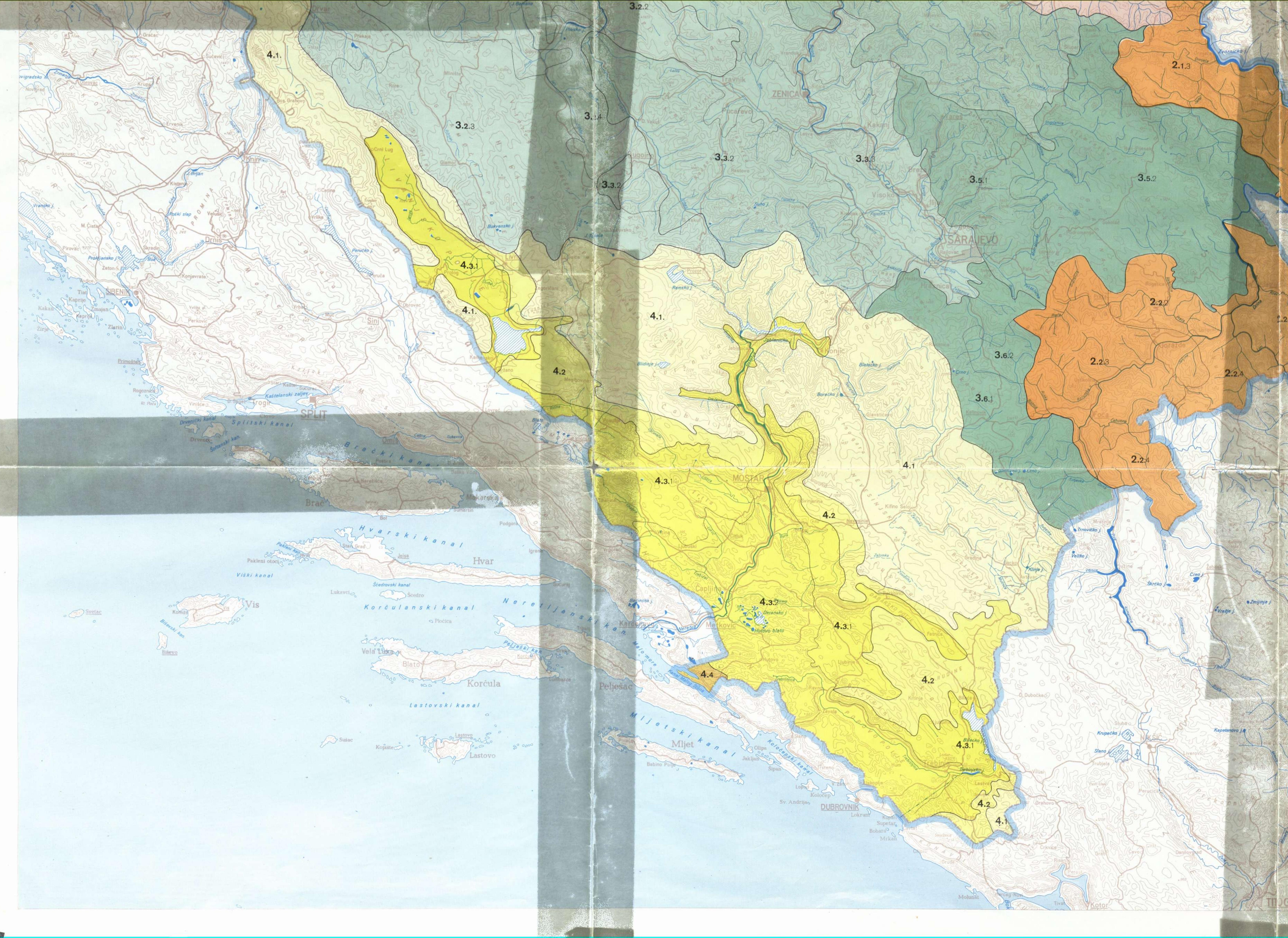

